\title{
A TERRA \\ E A CONSTRUÇÃO DE UMA POÉTICA DA LEVEZA
}

\author{
Heloisa Galvão
}

Dissertação apresentada ao Programa de Pós-Graduação em Artes, Área de Concentração Artes Visuais, Linha de Pesquisa Poéticas Visuais, da Escola de Comunicações e Artes da Universidade de São Paulo, como exigência parcial para obtenção do Título de Mestre em Artes, sob a orientação da Profa. Dra. Norma Tenenholz Grinberg.

São Paulo, Janeiro 2008 


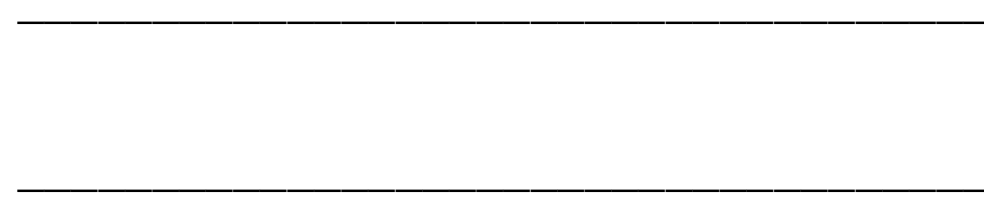

São Paulo, de de 2008 . 
“(...) a arte não se reduz ao objeto que resulta de sua prática, mas ela é essa prática como um todo: prática estética que abraça a vida como potência de criação, em diferentes meios, onde ela opera. Seus produtos são apenas uma dimensão da obra e não "a" obra: um condensado de signos decifrados que introduz uma diferença no mapa da realidade."

Suely Rolnik 
"Cada vez que o reino do humano me parece condenado ao peso, digo para mim mesmo que, à maneira de Perseu, eu devia voar para outro espaço. Não se trata absolutamente de fuga para o sonho ou o irracional. Quero dizer que preciso mudar de ponto de observação, que preciso considerar o mundo sob uma outra ótica, outra lógica, outros meios de conhecimento e controle. As imagens de leveza que busco não devem, em contato com a realidade presente e futura, dissolver-se como sonhos..."

Italo Calvino 


\section{Resumo:}

Esta pesquisa aborda a relação entre leveza e peso, entre matéria e imaterialidade, a partir do elemento terra. Compreende a criação de um conjunto de obras partindo dessa matéria densa, resistente, que tende ao peso, explorando seus limites, buscando leveza e imaterialidade. $O$ presente trabalho reúne os relatos dessa construção, bem como a reflexão de várias questões surgidas nesse percurso. Relata o resgate de técnicas tradicionais, como a porcelana translúcida e os processos de sensibilização de suportes fotográficos, que vêm da origem da fotografia. A partir de uma nova leitura dessa tradição é construída uma poética contemporânea. $O$ trabalho é permeado pela relação entre elementos bi e tridimensionais, pelo híbrido. Por um lado, a atenção se volta à forma e volumetria, e ainda à busca pela profundidade desse corpo a partir da translucidez da matéria. Por outro, o foco de interesse é puxado para a superfície, com a retomada da imagem fotográfica ao trabalho, numa tentativa de tridimensionalização da imagem.

\section{Palavras chave:}

leveza, terra, cerâmica, porcelana translúcida, processos fotográficos, tridimensão 


\section{Abstract:}

This research approaches the relation between the lightness and weight, between materiality and immateriality, starting from the element earth. It is the creation of a set of productions starting from this dense, resistant substance that tends to weight, exploring its limits, searching for its lightness and immateriality. The present work unites reports of this construction, as well as the reflexion of some questions that appeared during the process. It reports the recovery of traditional techniques, such as the translucent porcelain and the processes of sensitisation of photographic supports that come from the origin of photography. From a new interpretation of this tradition a contemporary form of poetics is constructed. The work is permeated by the relationship between bi-dimensional and three- dimensional elements and the hybrids. On one hand one's attention turns to the form and to the volumetric analysis, and furthermore to the search for depth of this body taking as starting point the translucency of the substance. On the other hand, the focus of interest is pulled to the surface, retaking the photographic image to my work, in attempt to create a three dimensional representation of the image. 
A meu pai, de quem herdei o gosto de trabalhar com a terra.

À minha mãe, com quem aprendi o significado de leveza. 


\section{Agradecimentos}

A minha orientadora, Profa. Dra. Norma Tenenholz Grinberg, por toda ajuda como conselheira, motivadora e pela amizade demonstrada.

A João, apoio e presença.

A meus pais e irmãos, presença importante mesmo a distância.

Lizette e Walter, família também.

A Cecília Almeida Salles, Evandro Carlos Jardim, Clara Luiza Miranda por toda contribuição no desenvolvimento deste trabalho.

Megumi Yuasa, Naoco e Plinio Cutaid, mestres queridos.

A Aparecida Mason, pelo cuidado e carinho na correção deste trabalho.

A Eric Jon Poschmann, Débora e Alberto Jacobsberg pelo apoio.

Meus amigos-ajudantes-parceiros queridos Ana Paula Lopes dos Santos, Lucélia Zamborlini, Juliana Brichesi, Eliana Blanc, Larissa Saito, Ana Galotti, Jessé Chaves, Julia Pacheco, Adriana Miranda, John Paul Lema, Ana Luiza Galvão, Carolina Pereira. 


\section{Sumário}

1 - Introdução

10

2 - Uma poética em desenvolvimento 14

2.1 - A cerâmica 23

2.2 - As Estruturas flexíveis 30

2.3 - Asas 39

2.4 - Leveza - nuvens 47

2.5 - Em busca de um corpo para o trabalho 49

2.6 - O retorno da imagem fotográfica 78

3 - Reflexões sobre a matéria. A terra 88

3.1 - Terra-água.

Reflexões sobre a forma 90

3.2 - Terra-ar.

Reflexões sobre sustentação e gravidade - leveza e peso

- o espaço

3.3 - Terra-fogo.

Reflexões sobre fragilidade e força - transformação

4 - Considerações finais

5 - Bibliografia

$6-$ Anexos

7 - Crêdito das imagens

102

107 


\section{1- Introdução}

Esta pesquisa trata do desenvolvimento de uma 'poética da leveza' a partir do elemento terra.

O termo poética vem do verbo grego poiein, que significa fazer, criar. Para Aristóteles, poética é a ação dada na criação artística.

Umberto Eco define poética "(...) não como um sistema de regras coercitivas ou normas absolutas, mas como um programa operacional que $o$ artista se propõe de cada vez: o projeto de obra a realizar tal como é entendido, explícita ou implicitamente, pelo artista."

Nesse momento, minha proposta é trabalhar com a terra, uma matéria densa, resistente, que tende ao peso, procurando chegar aos limites desse material, buscando leveza e quase imaterialidade. Estudar a leveza é, como afirma Ítalo Calvino, uma tentativa de tirar o pesadume das coisas, do mundo. Acredito na possibilidade da leveza, na transformação das coisas pesadas em leves. Não por desacreditar da importância do peso, mas como Calvino, por identificar-me com as questões da leveza. ${ }^{2}$

A linha de pesquisa em que este trabalho se insere, poéticas visuais, remete à idéia defendida por Júlio Plaza de que a relação a ser estudada deve ser uma

\footnotetext{
${ }^{1}$ ECO, 1971: 24

${ }^{2}$ CALVINO, 1990
} 
"síntese operativa do fazer-pensar." O autor cita Luigi Pareyson afirmando que o percurso do artista ao inventar sua poética se dá de tal forma que, "enquanto a obra se faz, se inventa o modo de fazer". ${ }^{3}$

No desenvolvimento deste trabalho, realizei pesquisas plásticas, experimentações de materiais e leituras de apoio. O texto é um ensaio em que levanto questões sem uma preocupação de pureza ideológica, mas passeio por diversos autores, levantando questões pertinentes ao trabalho, tecendo meu próprio texto sobre leveza, composto de linguagem escrita e, principalmente, de linguagem visual, a partir dos trabalhos plásticos construídos.

Executo um resgate de técnicas tradicionais, como a porcela translúcida, que foi segredo de famílias por centenas de anos na China e os processos de sensibilização de suportes fotográficos, vindos da origem da fotografia. A partir desse resgate, realizo uma transposição do antigo para o novo. A partir de uma nova leitura dessa tradição, desses materiais tradicionais construo uma poética contemporânea.

Para tanto, executo uma pesquisa quase laboratorial, retomando esses processos e desenvolvendo-os, adaptando-os para esse outro tempo-espaço em que ganham existência.

A matéria tem, neste trabalho, papel importante. No trabalho Nuvens fica explicitado como forma e matéria são uma coisa só, a matéria é desenho. O trabalho é formado a partir do comportamento da matéria.

${ }^{3}$ PLAZA, 2003: 37 
Os trabalhos desenvolvidos abordam a relação entre leveza e peso, entre matéria e imaterialidade. Trabalho com o frágil, com o tênue, quase informe. A relação espacial dos trabalhos revela elementos identificados como asas, como nuvens, elementos do ar, signos da leveza. A matéria terra, através de sua nova conformação e disposição espacial, ganha uma outra visualidade, a visibilidade das coisas do ar.

No primeiro capítulo, descrevo meu percurso, desde minha pesquisa inicial com os processos fotográficos históricos, meu aprendizado com a cerâmica, o desenvolvimento do corpo translúcido, a retomada dos processos fotográficos e sua relação com o suporte cerâmico. Este trabalho é permeado pela relação entre elementos bi e tridimensionais, pelo híbrido. Por um lado, a atenção se volta à forma e volumetria, e ainda à busca pela profundidade desse corpo a partir da translucidez da matéria. O corpo translúcido representa a possibilidade do olhar atravessar a matéria junto com a luz. Por outro lado, o foco de interesse é puxado para a superfície dessa matéria com a retomada da imagem fotográfica ao trabalho.

No capítulo seguinte, levanto algumas questões presentes nesta etapa da pesquisa, que vão se desenvolvendo, à medida que vou trabalhando. São reflexões sobre leveza e peso, fragilidade e força, transformação da matéria, forma, espaço. Relacionei esses questionamentos com a matéria terra e as relações que esta tece com os outros elementos - água, ar e fogo - dentro da cerâmica. Separo as relações da terra com os outros elementos individualmente e demonstro as relações próprias do encontro dessas duas matérias, do momento 
em que essa relação é dominante na cerâmica, no meu trabalho e nos meus questionamentos. O presente texto é apenas um recorte de um trabalho em constante construção.

Cecília Almeida Salles, em seus estudos sobre os processos de criação artística, dentro da Crítica Genética, descreve essa seqüência de movimentos hipotéticos, esse não definitivo, esse processo de contínua metamorfose:

"O que está em jogo é a variação dos estados, a confrontação de uma obra com todas as possibilidades que a compõem, tanto com relação ao que vem antes, quanto ao que vem depois. E a mobilidade complexa e a estabilidade precária das formas." ${ }^{4}$

\footnotetext{
${ }^{4}$ SALLES, 2000: 45
} 


\section{2- Uma poética em desenvolvimento}

O desejo de trazer a forma para o espaço, de construir corpos tridimensionais me ocupa desde que trabalhava a fotografia como meio principal de expressão. Em 1997, iniciei uma pesquisa com processos fotográficos históricos, tendo como ponto de partida a investigação dos processos fotográficos empregados no período de invenção da fotografia. Em seguida, passei a retomar esses processos com o intuito de dominar as técnicas de sensibilização de superfícies variadas, para então poder considerar a fotografia no espaço tridimensional, como objeto, como corpo nesse espaço.

"O retorno às técnicas de fotografia anteriores aos processos industriais foi para mim um encontro com as possibilidades de construção que procurava(...) uma busca de liberdade para a minha fotografia. Vê-la presa à rigidez de uma superfície plana me incomodava.

A fotografia me parecia objetiva demais. Buscava no meu trabalho um diálogo entre o espaço real e a realidade criada. Queria construir... Queria a construção. ${ }^{5}$

A possibilidade de manipular diretamente a matéria, de conhecer suas qualidades era, e ainda é, um grande interesse a ser trabalhado. Muitas possibilidades se abrem a partir do contato direto com a matéria, com todas as suas potencialidades e variantes expressivas.

\footnotetext{
${ }^{5}$ GALVAO,1999: 6
} 
Visando a trimensionalidade e a manipulação direta da matéria, pesquisei processos fotográficos, tais como Cianótipo, Van Dyck Brown, Albúmem, Goma Bicromatada. O processo do Van Dyck Brown utilizado é uma simplificação do Calótipo, inventado por William Henry Talbot em 1839. Ele sensibilizava um papel de escrever delicado, mergulhando-o numa solução de água e cloreto de sódio e, depois de seco, passava nitrato de prata. Primeiro, trabalhou na obtenção das imagens diretamente, a partir da câmara escura, depois, descobriu como repetir as imagens em positivo: encerava suas fotografias e usava-as como negativo para obtenção dos positivos. Chamou essas imagens de 'desenhos fotogênicos'. Descobriu não só a imagem latente, mas também como revelá-la.

O Cianótipo foi inventado por Sir John F. W. Herschel, na Inglaterra, em 1842. Por ser um processo simples e de baixo custo, foi muito utilizado por fotógrafos amadores no final do século XIX. É baseado nas propriedades fotossensíveis de alguns sais férricos como citrato férrico amoniacal e ferricianeto de potássio, que, em presença de luz, são sensibilizados, passando ao estado ferroso. Sua denominação derivaria da terminologia de um dos componentes de sua formulação: ferricianeto de potássio; ou ainda da cor obtida no processo: cian. Esse processo foi utilizado, também, na produção de desenhos e plantas por contato, denominado blue print.

O Albúmem ou Papel Albuminado, como era chamado, foi desenvolvido por Louis-Désiré Blanquart-Evrard, em 1850. Foi, também, muito popular no final do século XIX devido à simplicidade de sua formulação e também pela riqueza de tons que proporciona. Esse processo utiliza albumina de ovo como base e nitrato 
de prata como elemento fotossensível. Podia ser aplicado sobre vidro para a obtenção de negativos, mas a sua principal aplicação foi sobre papel para a obtenção da imagem positiva, a partir dos negativos de colódio úmido. Foi muito usado nos cartes-de-visite $(6,5 \times 10,5 \mathrm{~cm})$ e cabinet $(11 \times 16,5 \mathrm{~cm})$, os formatos de fotografia mais comuns na época. Foi gradativamente substituído pelos papéis de gelatina com sais de prata.

O processo da Goma Bicromatada foi introduzido por A. Rouillé-Ladé Vèze, em 1894. A goma arábica era misturada a pigmentos coloridos e passada sobre o papel, que depois era sensibilizado com bicromato de potássio e exposto à luz. Era lavado com água morna, permanecendo sobre o papel apenas nas áreas insolubilizadas pela luz. A imagem podia ser modificada durante a lavagem, podendo parecer com um desenho a carvão. O processo podia ser repetido várias vezes para a obtenção de cores e tons variados.

Visando a ampliação dos meus recursos de expressão, retomei esses processos, passando a preparar minhas próprias soluções fotossensíveis, sensibilizando tecidos e papéis variados. Esses suportes eram expostos à luz solar ou a uma caixa de luz construída. Não é possível trabalhar com ampliadores comuns, pois essas soluções não são tão sensíveis como o papel fotográfico industrial. A imagem é passada por meio de contato com negativos ampliados.

$\mathrm{Na}$ aplicação das emulsões, procurei sempre explorar o gesto, a pincelada da solução fotossensível sobre o suporte, como se estivesse pintando. O resultado são imagens que nascem das pinceladas, uma fotografia pintada sobre o suporte. 
Fig. 1

Sem titulo, 1998

Imagem em Cianotipia sobre papel

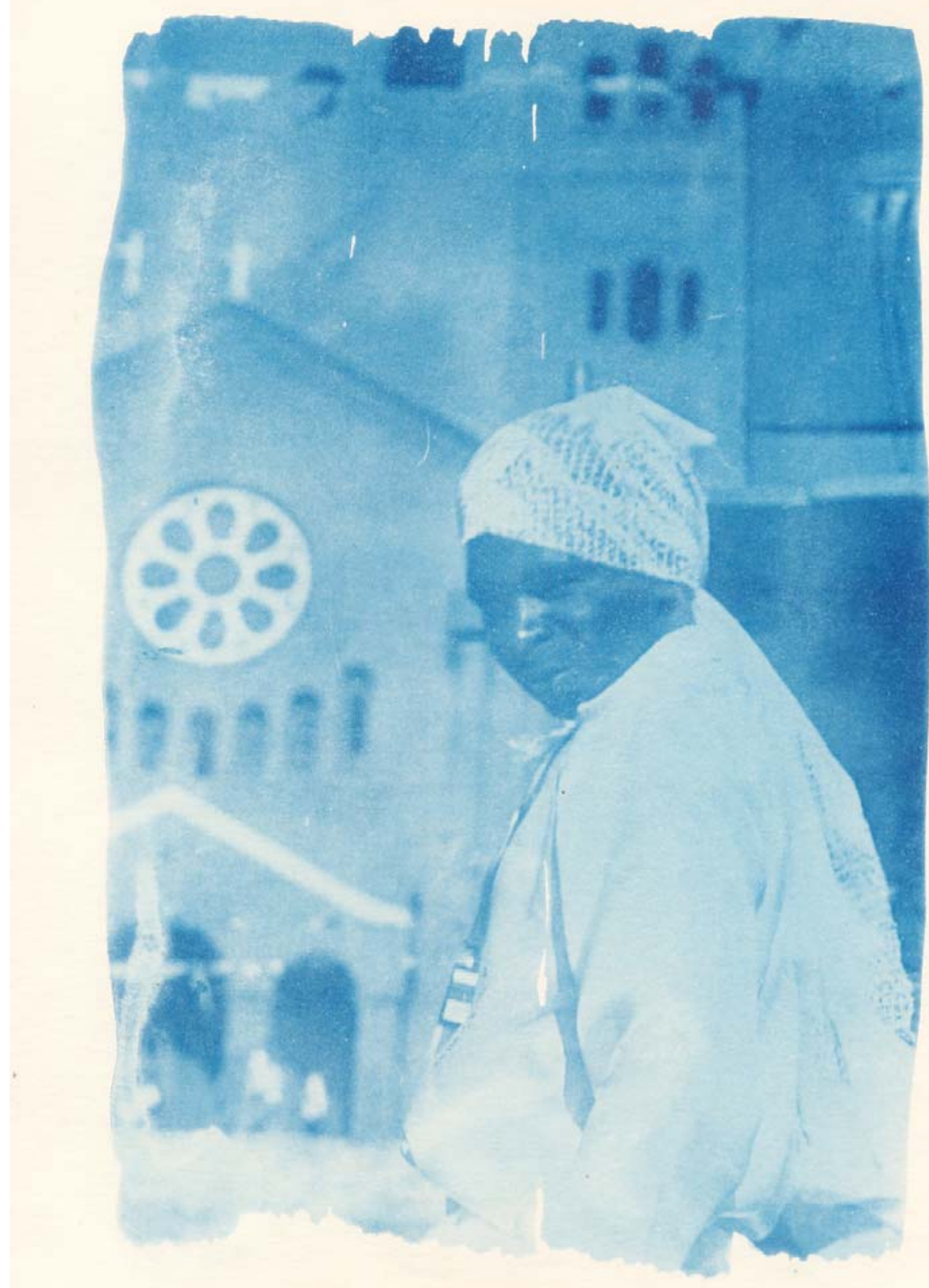


As imagens assim produzidas tinham como tema a cultura popular e foram captadas em festas de congado no Espírito Santo e Minas Gerais. Evocavam a paisagem humana dessas manifestações folclóricas, o homem popular, seus traços, e a valorização de seus símbolos e mistérios. Cito em minha monografia de conclusão de curso uma fala da pesquisadora Dra Renata Meira Bittencourt:

"A explicação realista é clara e insolúvel demais para ser aplicada às mil e uma cambiantes dos fenômenos da vida coletiva. Precisa ter mistério, precisa ser simbólica. O homem popular está mergulhado em símbolos e mistérios dinâmicos que, para nós, são impalpáveis e para ele, indizíveis. Por isso dançam, cantam e representam esse universo intangível." ${ }^{\circ}$

Trabalhando diretamente com a matéria, manipulando-a na produção da imagem, destacava desde esse momento um interesse no impalpável, no inefável. Aqui já se fazia presente a relação entre a superfície, o aspecto externo, a pele e o aprofundamento dessa superfície.

As imagens feitas em tecido de algodão fino tornavam-se translúcidas, a luz podia atravessá-las. A pele tornava-se fina, permeável. Era possível penetrar a superfície, ver além dela... O olhar pode atravessar essas imagens e elas tornamse suaves, tênues. O trabalho ganha uma leveza que o difere das fotografias feitas em papel industrializado.

Os resultados obtidos foram me agradando muito. Realizei algumas instalações com essas imagens em tecido. Mas procurava ainda maiores possibilidades de tornar o trabalho tridimensional.

${ }^{6}$ MEIRA, Renata Bittencourt, apud GALVAO, 1999:16. 
Fig.2

Sem titulo, 1998

Imagem em Van Dyck Brown sobre papel

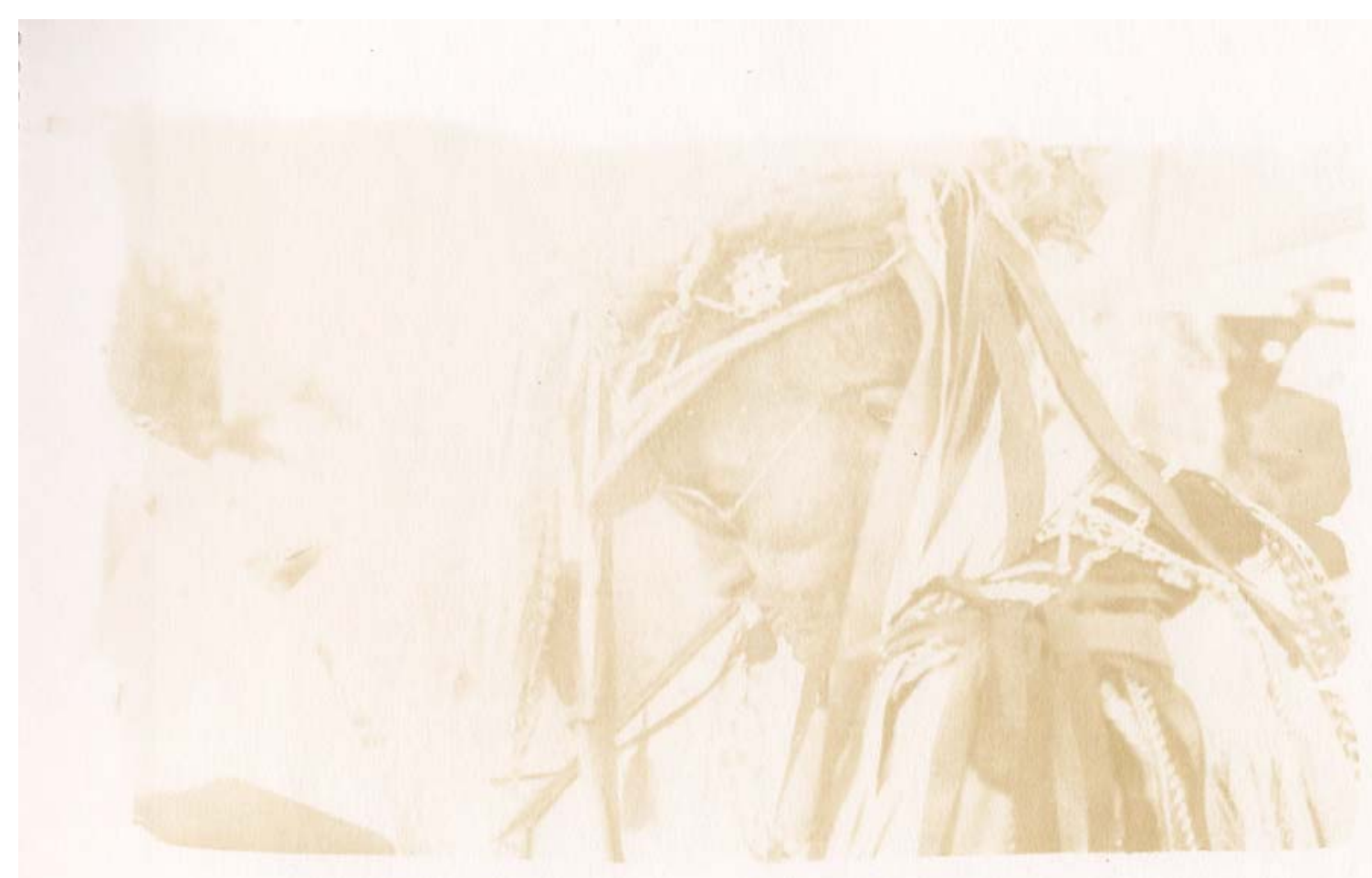


Fig.3

Sem titulo, 1998

Imagem em Van Dyck Brown sobre tecido

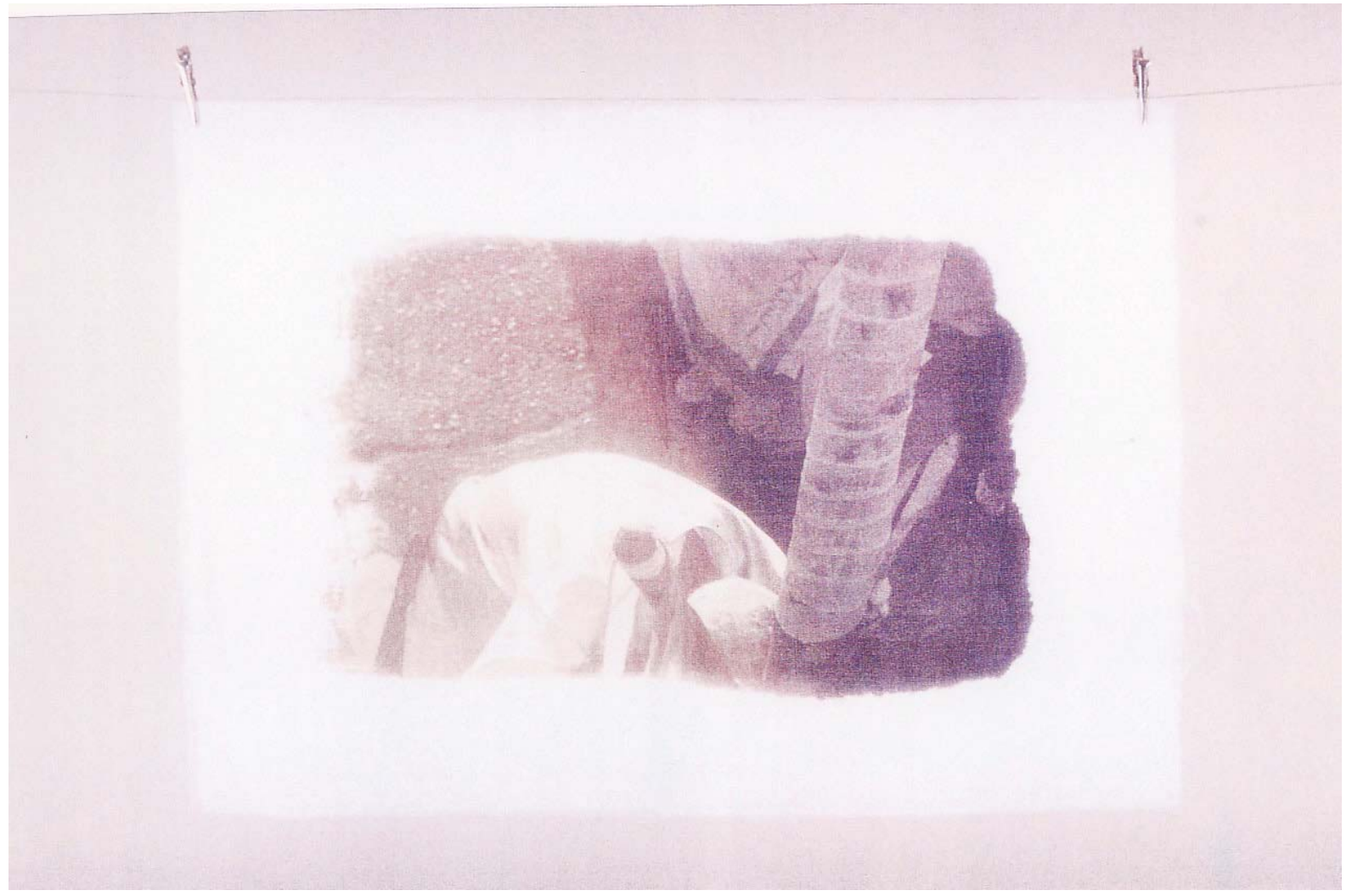


Fig. 4

Detalhe de instalação

com imagem de Cianotipia

sobre lencos de tecido

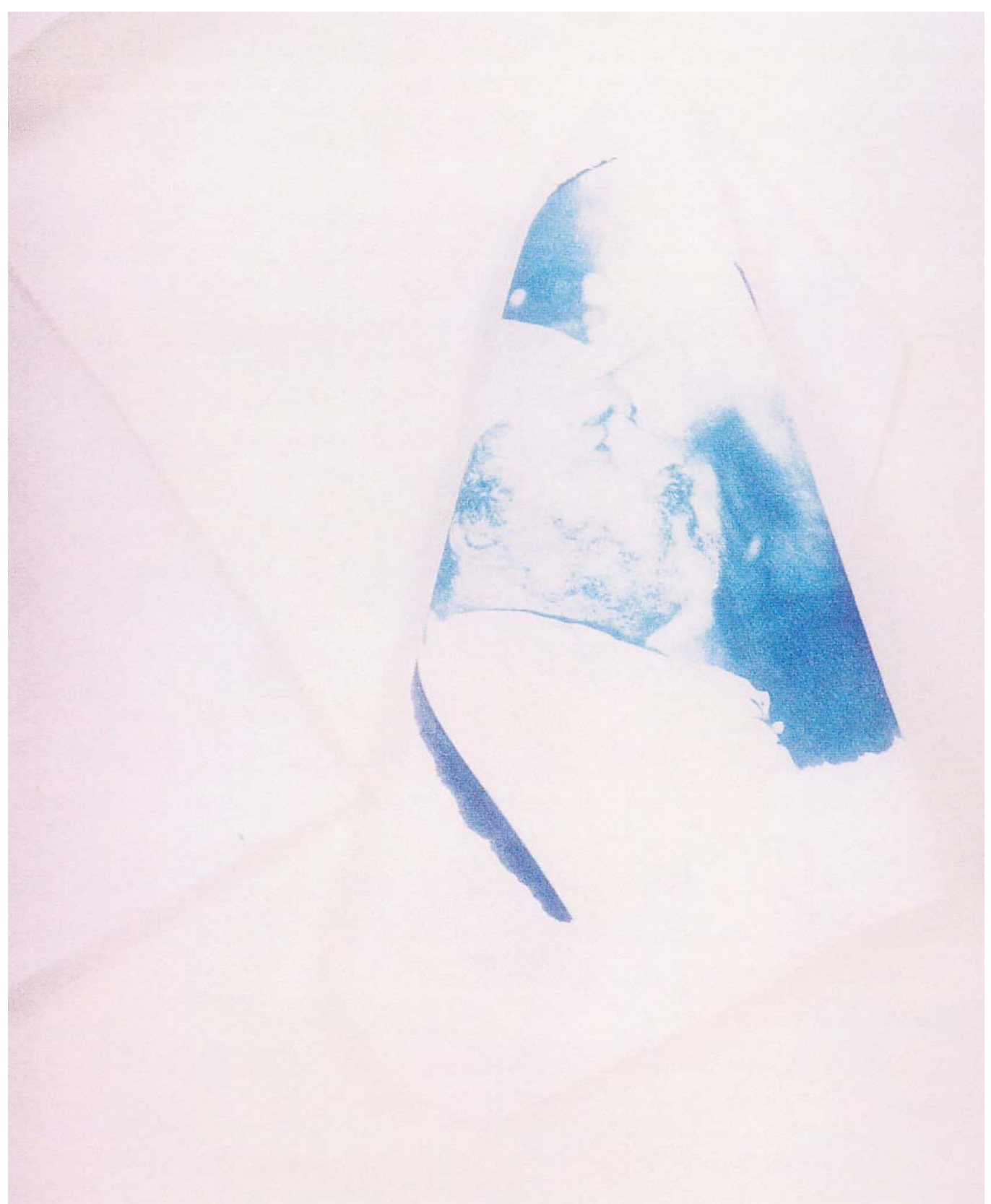


Fig.5

Sem título, 1999

Instalação com imagem de Cianotipia sobre lencos de tecido

Salão do Mar, Vitória, ES

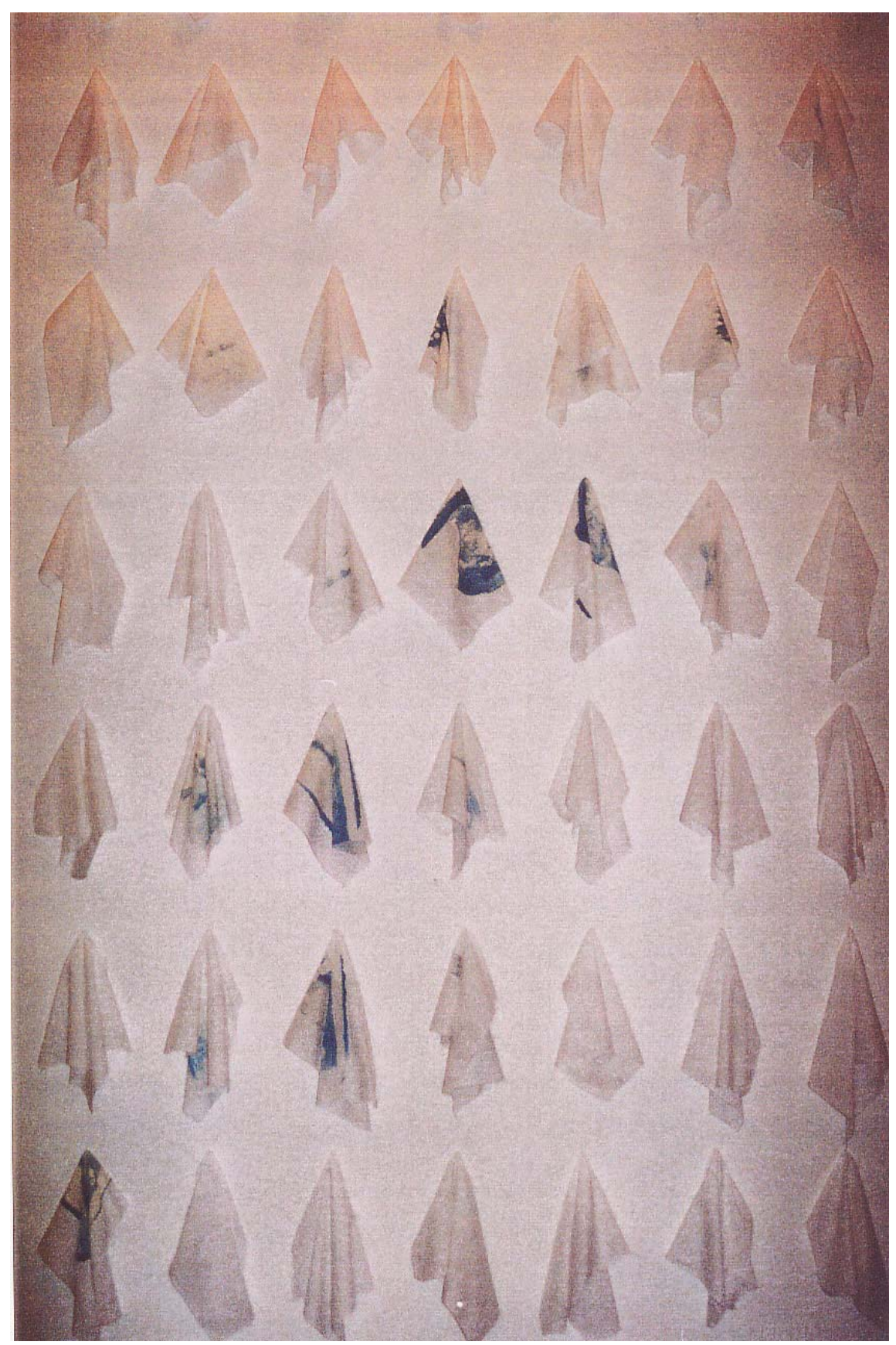




\section{1- A cerâmica}

O interesse pela cerâmica veio das possibilidades construtivas que a argila apresenta. Num primeiro momento, o objetivo era utilizar a cerâmica como um suporte para as sensibilizações fotográficas, mas ela se mostrou muito mais que isso. A forte relação entre matéria, manipulação e construção presente nesse material captou minha atenção. A matéria abriu um novo campo de possibilidades. A cerâmica passou então a ter lugar central em minha pesquisa poética.

Em 1999, comecei a me dedicar exclusivamente à investigação dessa matéria. Fiz diversos cursos e tive contato Megume Yuasa, meu grande mestre. Em meu primeiro encontro com Megume, ouvi a seguinte frase: "somos todos metade ceramistas sem nunca ter feito cerâmica. A maior parte da coisa já está aqui, basta estar vivo." Megume afirma que o Planeta Terra é uma cerâmica e estudar cerâmica ajuda a encontrar a própria origem, perceber que o eu é continuação disso, é parte do globo.

Comecei a me dedicar à produção diária de cerâmica. Montei um atelier em Vitória, ES, que foi para mim um espaço de pesquisa e criação, onde experimentei massas, esmaltes, temperaturas e formas.

Passei muito tempo construindo potes: esse container mais simples e primitivo, esse invólucro do vazio, essa forma primordial, que veio em substituição às mãos postas. Há um escrito Taoísta sobre o vazio, no Tao Te Ching, de LaoTzu: 
Trinta raios unem um eixo.

A utilidade da roda vem do vazio.

Queima-se o barro para fazer o pote.

A utilidade do pote vem do vazio.

Rasgam-se janelas e portas para criar o quarto.

A utilidade do quarto vem do vazio.

\section{Portanto,}

Ter leva ao lucro,

Nao ter leva ao uso. ${ }^{7}$

\footnotetext{
${ }^{7}$ LAU-TZU, 2002: 11.
} 
Fig.6

Detalhe de potes

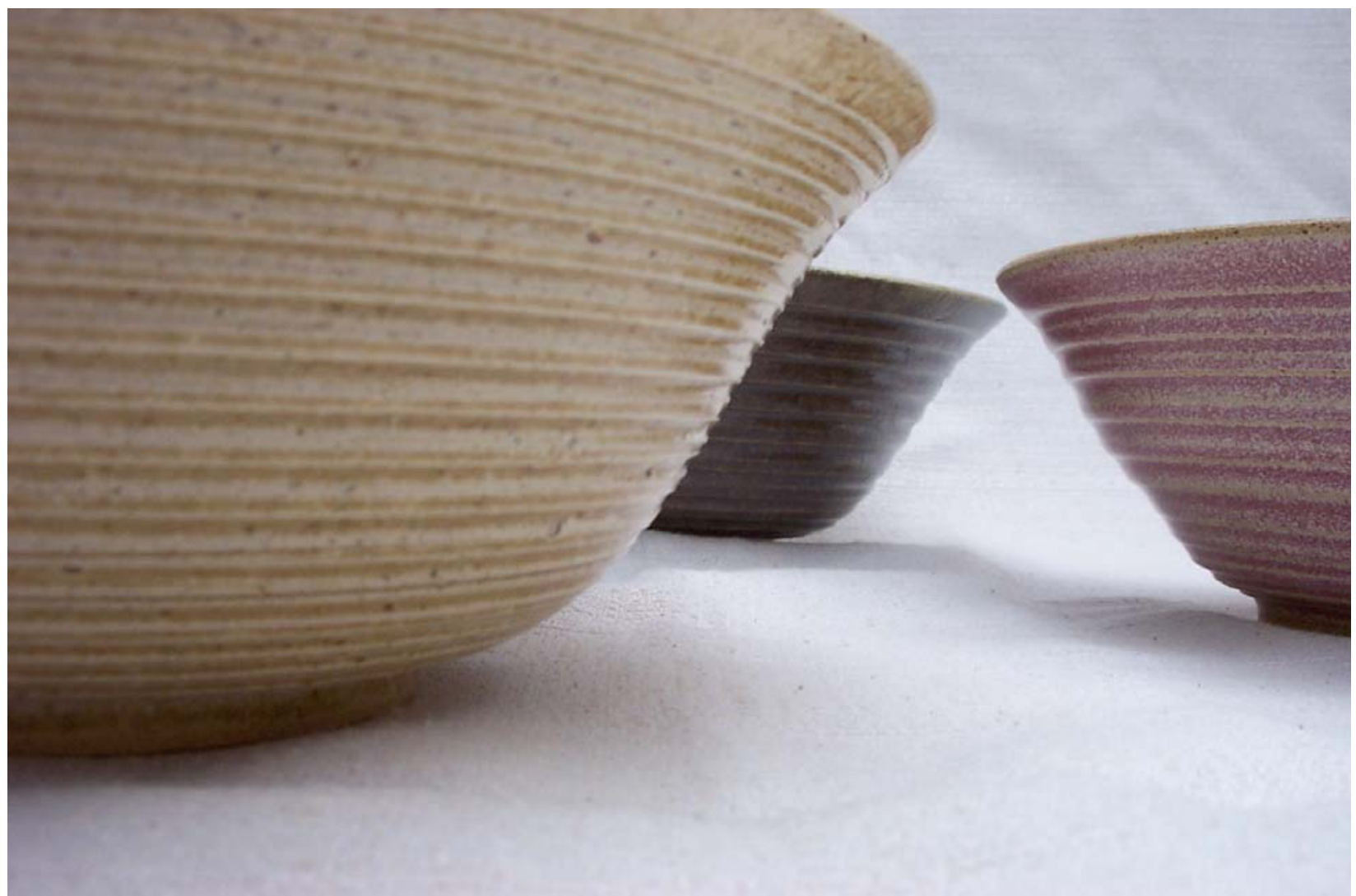




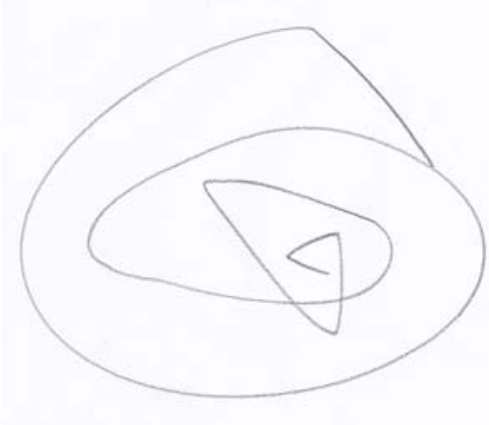

Fig.7

Desenvolvimento de peças

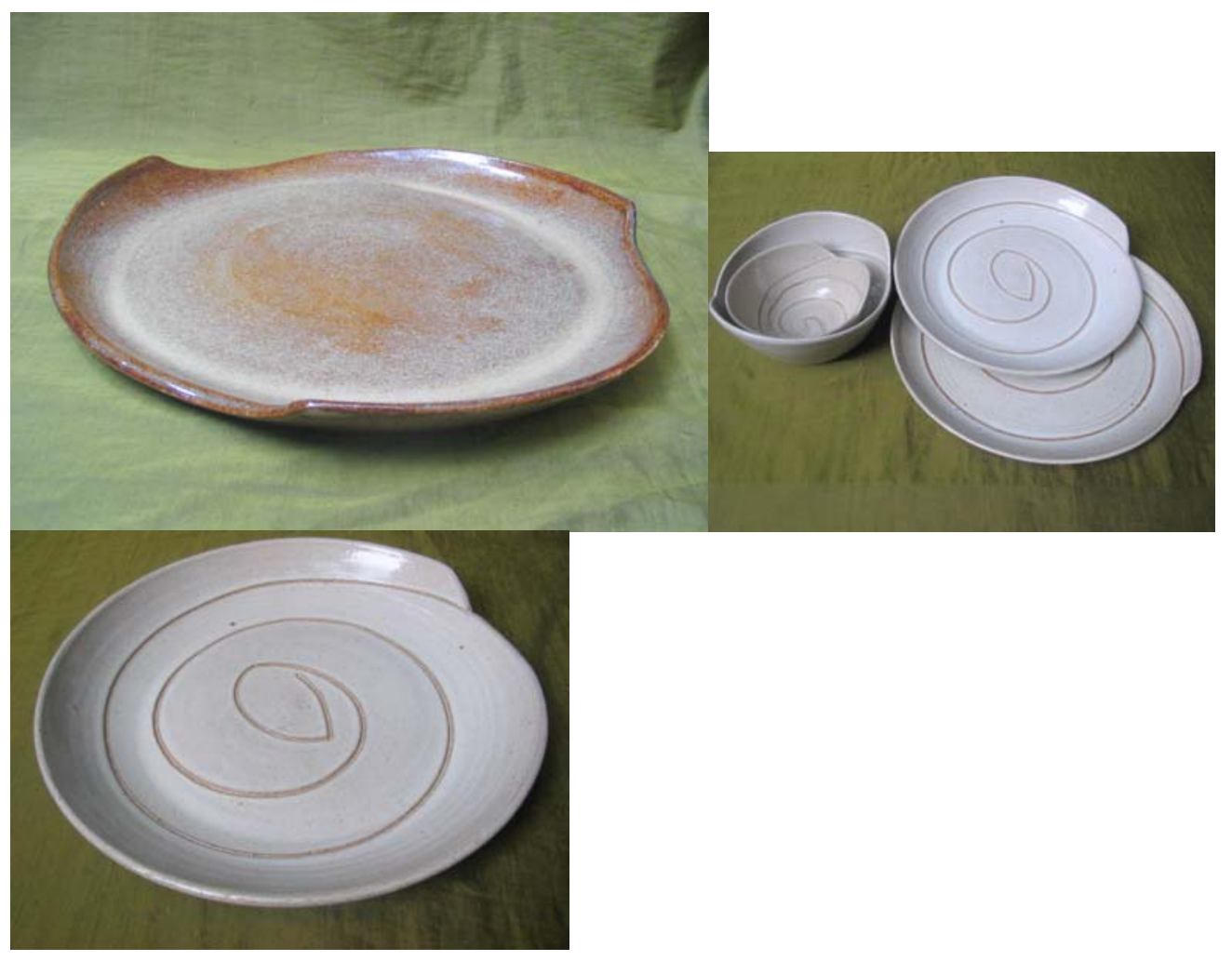

Depois multipliquei as formas. Passei a produzir utilitários pensando sempre na aproximação, na intimidade que as pessoas têm com seus objetos do cotidiano.

Tinha encontrado as possibilidades de construção que tanto queria: um universo. Havia ali uma nova via de acesso, um espaço novo, o dia-a-dia das pessoas. Essas peças se completam no uso, quando se tornam plenas. Esse trabalho se multiplicou. 
Fig. 8

Detalhe de pratos

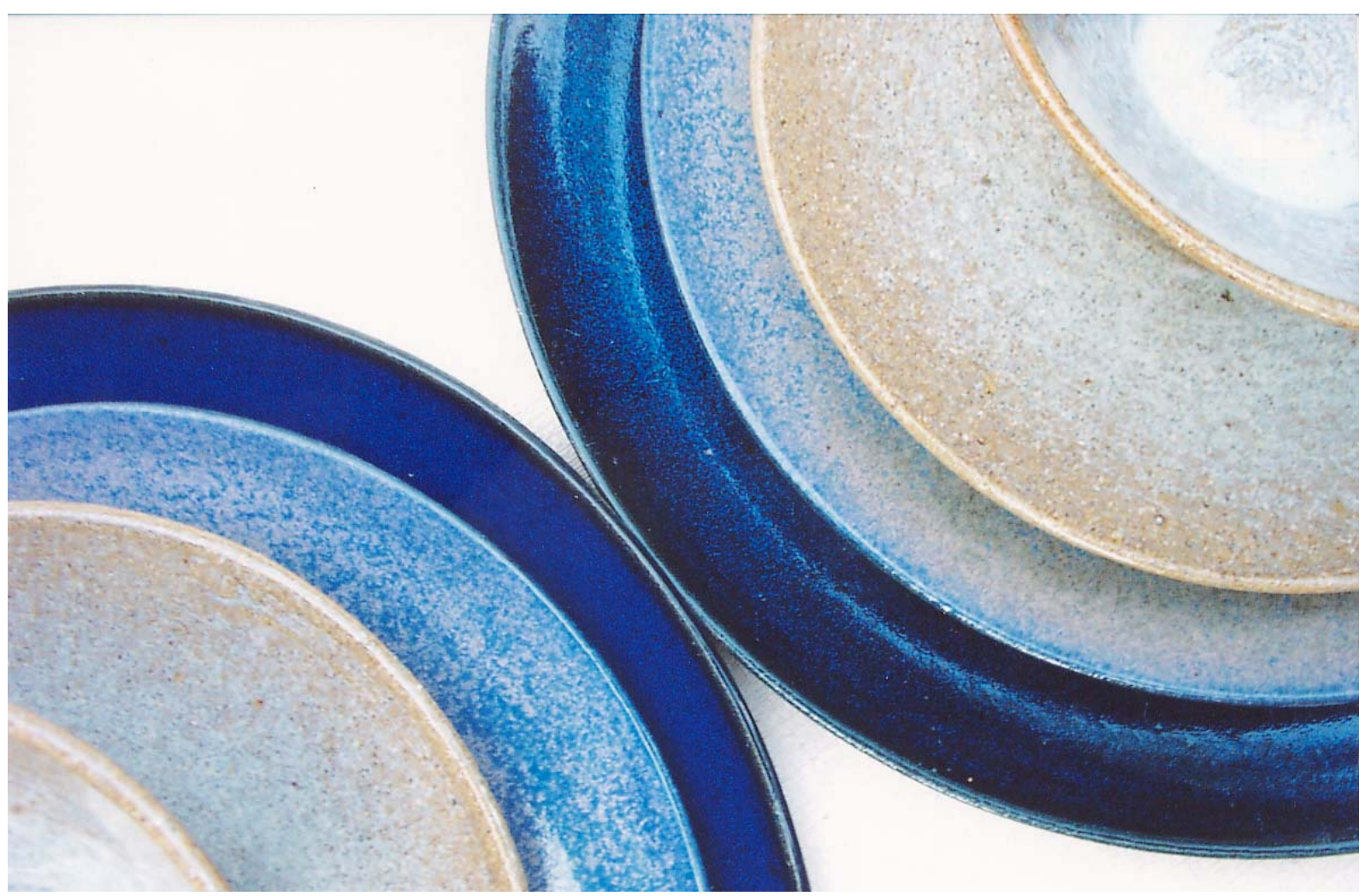




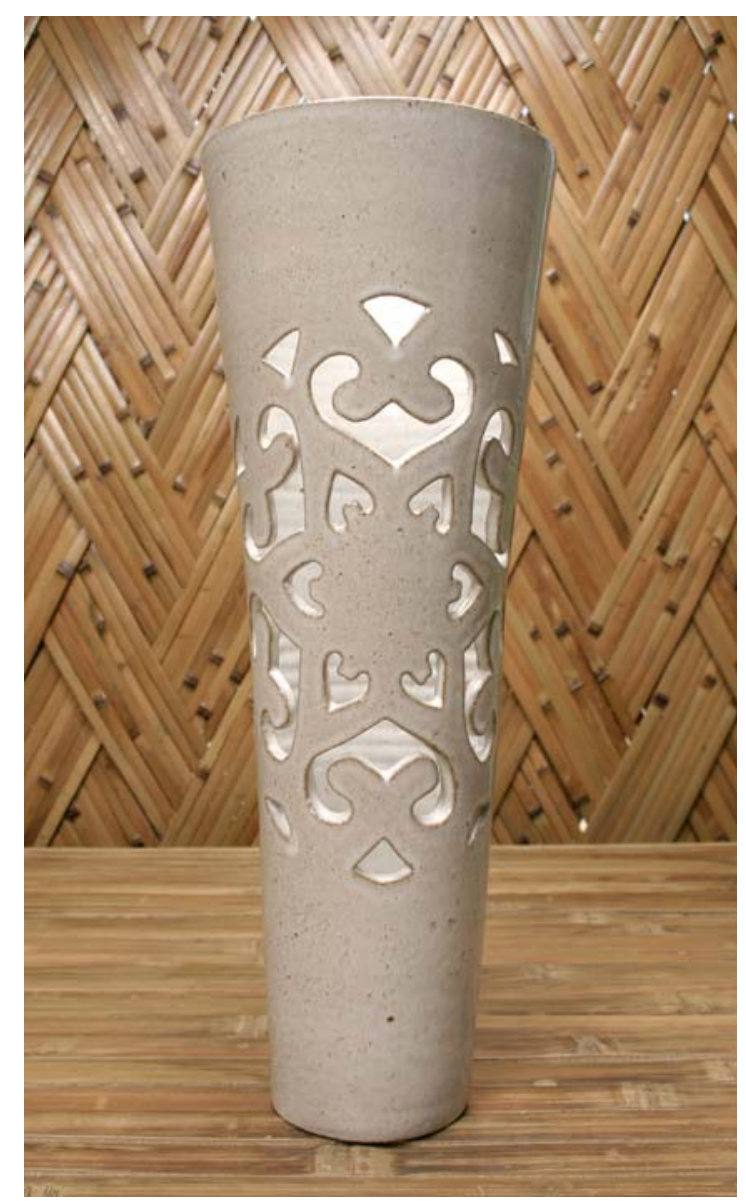

As peças foram sendo trabalhadas cada vez mais leves, com as paredes cada vez mais finas. Comecei, então, a testar os limites do material. Iniciei uma série chamada "Rendas", em que trabalhava recortes de papel e transpunha para a cerâmica. A primeira peça dessa série teve de ser refeita oito vezes, até conseguir sustentar-se, passando por todo o processo de feitura, secagem, primeira queima, esmaltação e queima em alta temperatura $\left(1240^{\circ} \mathrm{C}\right)$. A partir dessa peça, desenvolvi uma linha de peças com recortes. Por meio desses elementos vazados, a luz podia atravessar a parede da peça, entrando ou saindo.

Fig. 9

Vaso da série rendas 
Fig. 10

Detalhe de renda circular em cerâmica

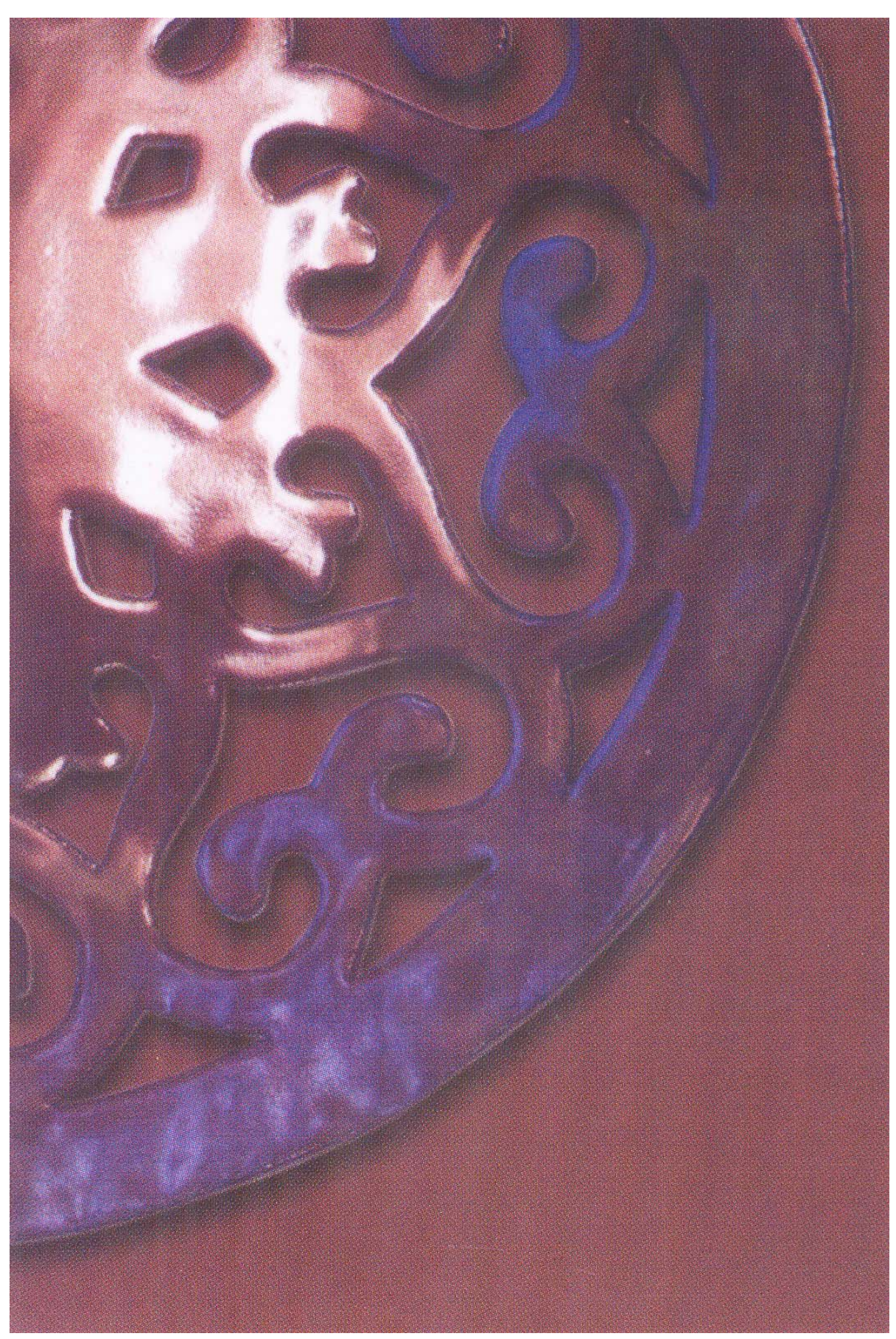




\section{2 - As Estruturas flexíveis}

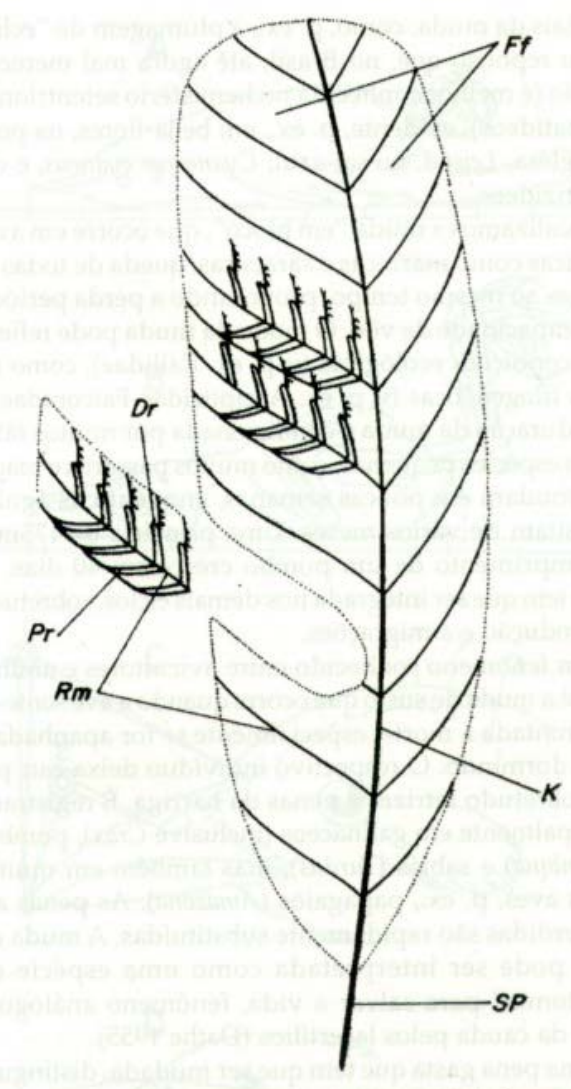

- Pena de uma ave (rêmige secundária de un sabiá, asa esquerda, vista de cima), esquema. $D r$, barbicela anterior ou distal possuindo ganchinhos; $F$, vexilos (à direita vexilo externo, à esquerda vexil interno); $K$, raque, haste, $P r$, barbicela posterior ou (seg. H. Sick 1937)

Fig.11

Detalhe da estrutura

das penas
Em 2002, comecei a atentar para uma forma, que se repete inúmeras vezes, na natureza, na estruturação de diversos seres: um eixo central de onde partem linhas diagonais para ambos os lados, às vezes simétricas, às vezes não. Esse esquema de estruturação presente nas penas das aves, nas espinhas dos peixes, nas colunas vertebrais, nas folhas, está ligado à sustentação e flexibilidade desses seres, como estruturas possibilitadoras de movimento. Nas aves, por exemplo, essa estrutura é responsável por formar nas penas de vôo - como são chamadas as penas das asas e da cauda - um tecido flexível e resistente, que não cede à intensa pressão do ar, possibilitando o vôo.

Nas espinhas dos peixes e na coluna vertebral dos mamíferos, essa estrutura tem função semelhante. Seu rompimento ou dano compromete o movimento, podendo acarretar paralisia nesses seres. Nas folhas, essa configuração aparece novamente, bem marcada, conferindo a resistência e flexibilidade que possuem. 

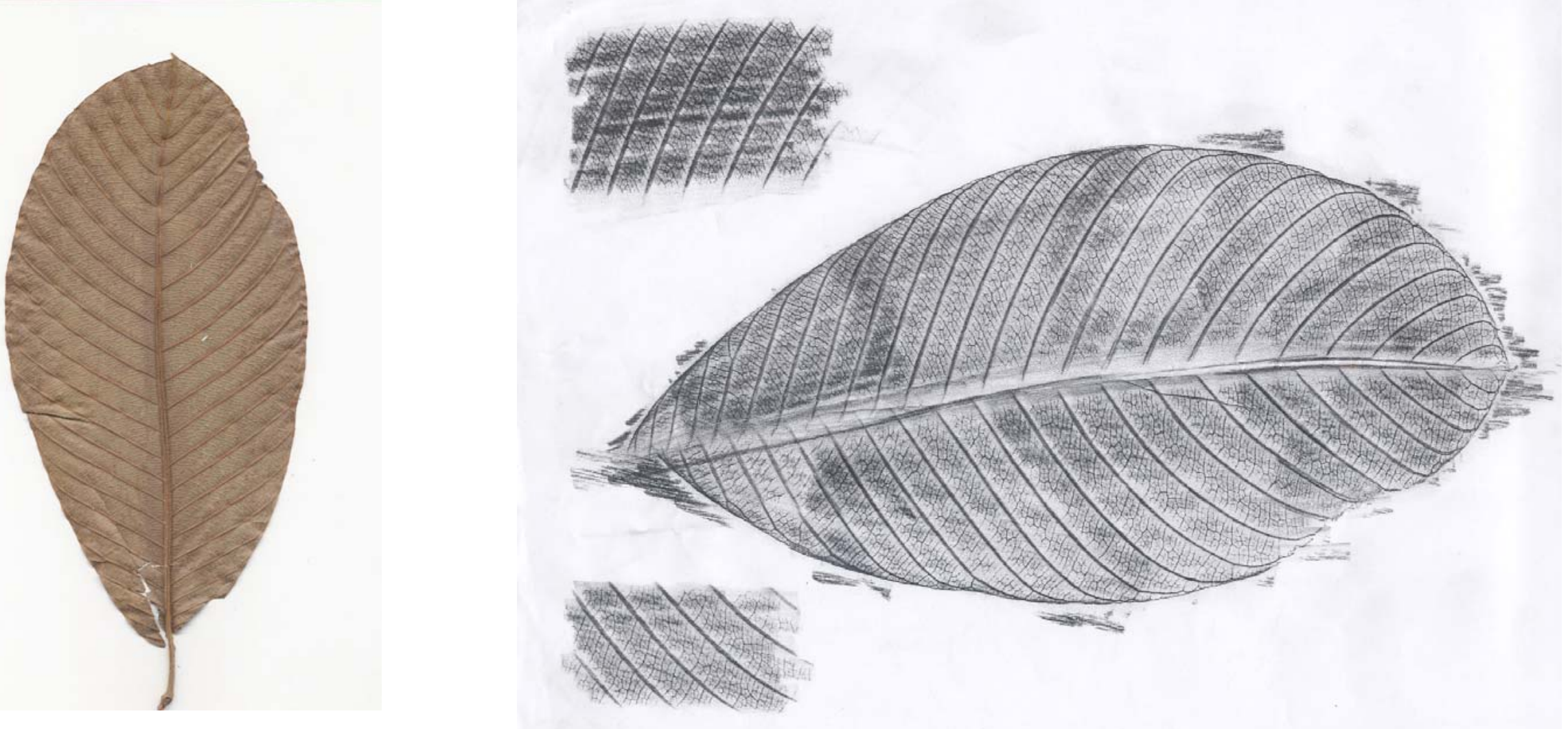

Fig. 12

Estudo de folhas 

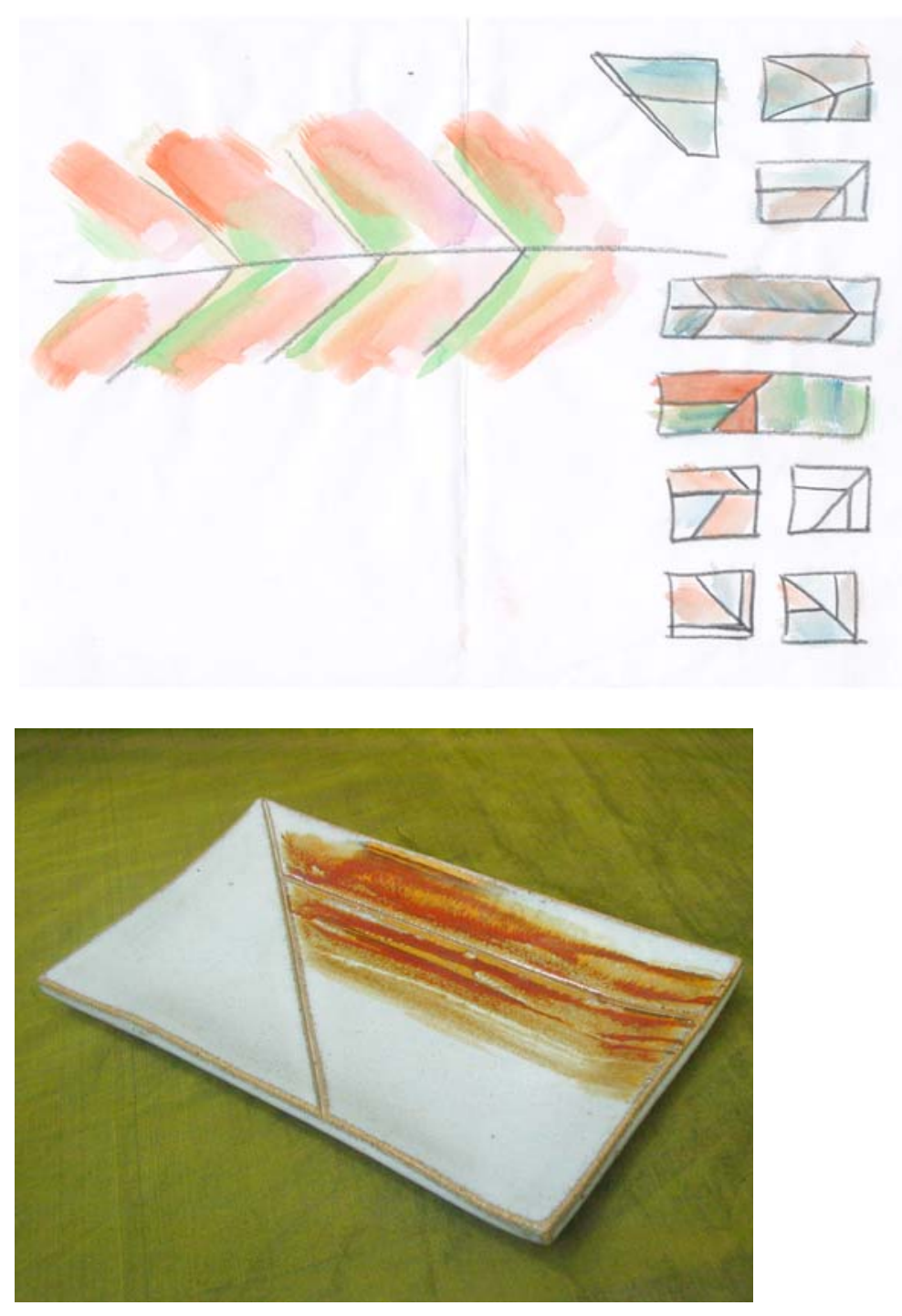

Fig. 13

Desenvolvimento de peças

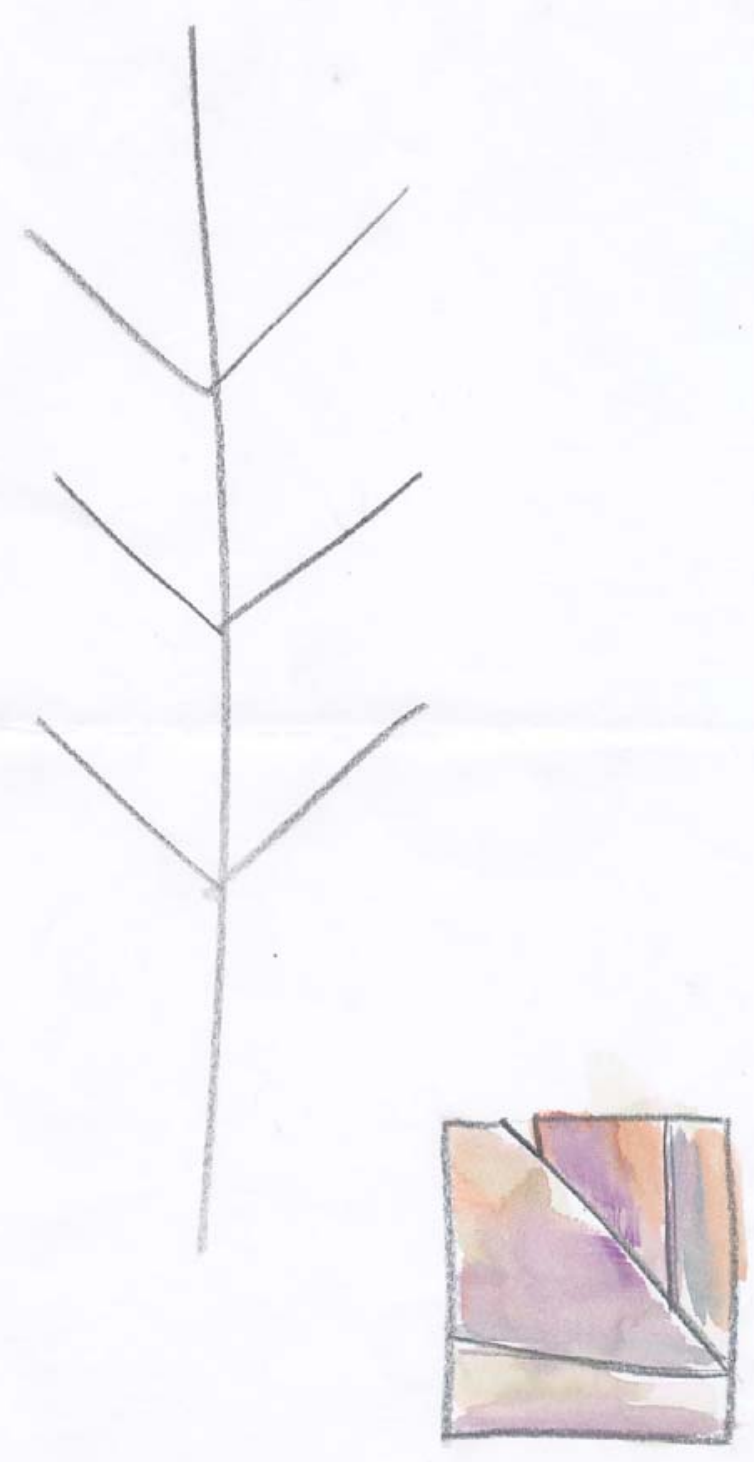


Uma série de questões começaram a surgir naquele momento, a partir de um conceito fechado de estruturas rígidas: qual é a importância de estruturas para a sustentação e a possibilidade de movimento? Estruturas seriam em si mesmas contrárias à idéia de movimentação? O termo estrutura comportaria em si mesmo a idéia de rigidez? Existem estruturas flexíveis?

Encontrei em Zigmunt Bauman uma análise interessante sobre segurança e liberdade, e teci então uma livre relação entre essa análise e as questões de estruturação e movimento. Em "O mal estar da pós-modernidade", Bauman faz uma análise dos conceitos de liberdade e segurança, relacionando a análise dos mesmos feita por Freud na modernidade, em "O mal estar da civilização". Freud afirma que "[...] o homem trocou um quinhão de suas possibilidades de felicidade por um quinhão de segurança [...]"8. Bauman contrapõe: na pós-modernidade ocorre uma inversão, as perdas e ganhos mudam de lugar, o homem troca suas possibilidades de segurança por um quinhão de felicidade, que o autor traduz como liberdade. "A liberdade individual reina soberana", mas o mal estar permanece. Liberdade em detrimento de segurança não irá assegurar a tão procurada felicidade. $^{9}$

\footnotetext{
${ }^{8}$ FREUD, apud BAUMAN, 1998:8.

${ }^{9}$ BAUMAN, 1925:10.
} 


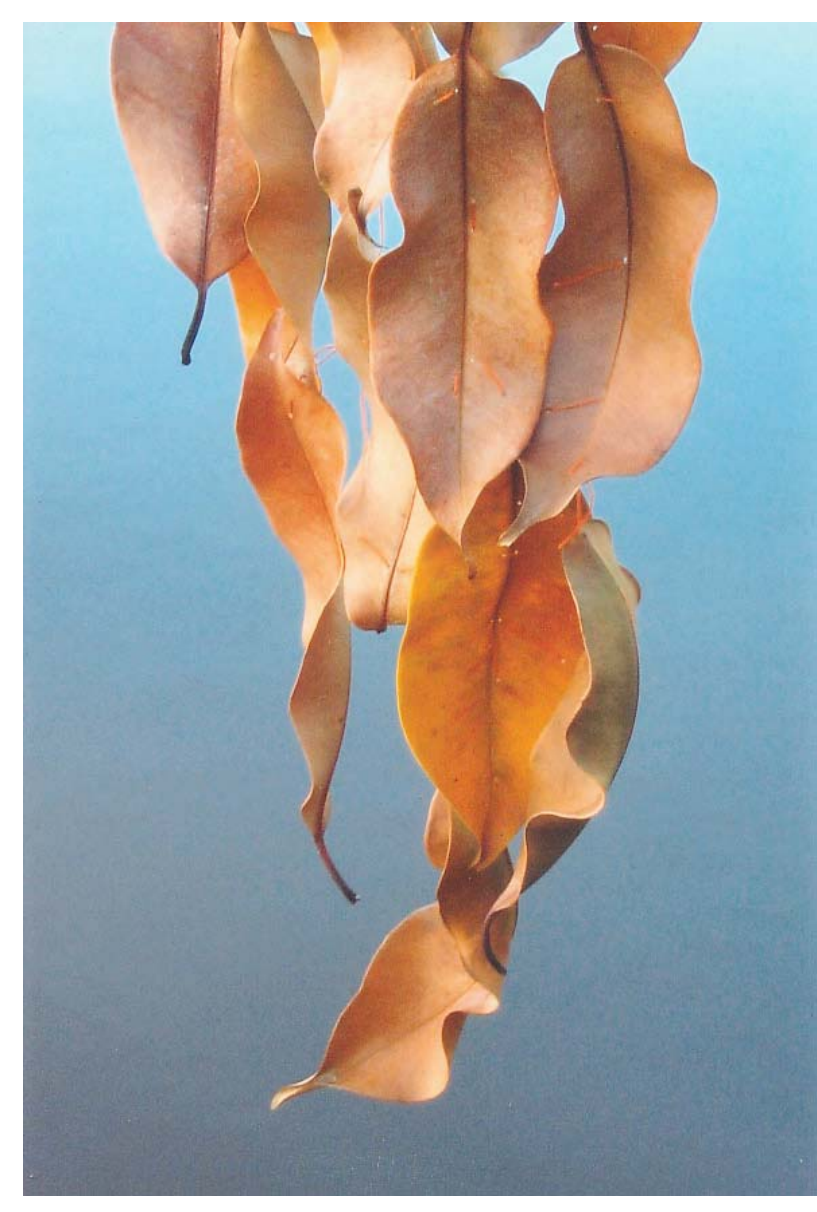

Fig. 14, 15, 16, 17, 18

Detalhe de trabalho feito com folhas secas e costura, remetendo às

'estruturas flexíveis'
Fiz, então, uma relação poética ligando o conceito de liberdade à flexibilidade e movimento, enquanto segurança estaria relacionada a estruturas rígidas, estáticas. Considerando meios de criar estruturas que sustentem a liberdade almejada, uma base de segurança para a ação, para o movimento. Comecei a imaginar formas de equilíbrio não visto como aproximação entre forças opostas, visando igualdade absoluta, mas como balanceamento entre os aparentemente opostos. Derrida afirma que um movimento em busca de síntese conduziria à simples neutralização dessas oposições. ${ }^{10}$ Não existe uma forma definitiva, estática de equilíbrio, mas uma relação móvel, contínua entre as diferenças.

Esses questionamentos estão presentes em todo decorrer do trabalho, nas relações estabelecidas entre leveza e peso, entre fragilidade e sustentação, terra e ar, rígido e maleável, passivo e ativo, claro e escuro, interioridade e exterioridade, permanente e efêmero, emoção e razão, consciência e inconsciência, destruição e construção, ordem e desordem, sempre buscando esse equilíbrio na dinâmica do encontro e complementação móvel entre diferentes.

${ }^{10}$ PONTIFÍCIA UNIVERSIDADE CATÓLICA DO RIO DE JANEIRO, 1976. 


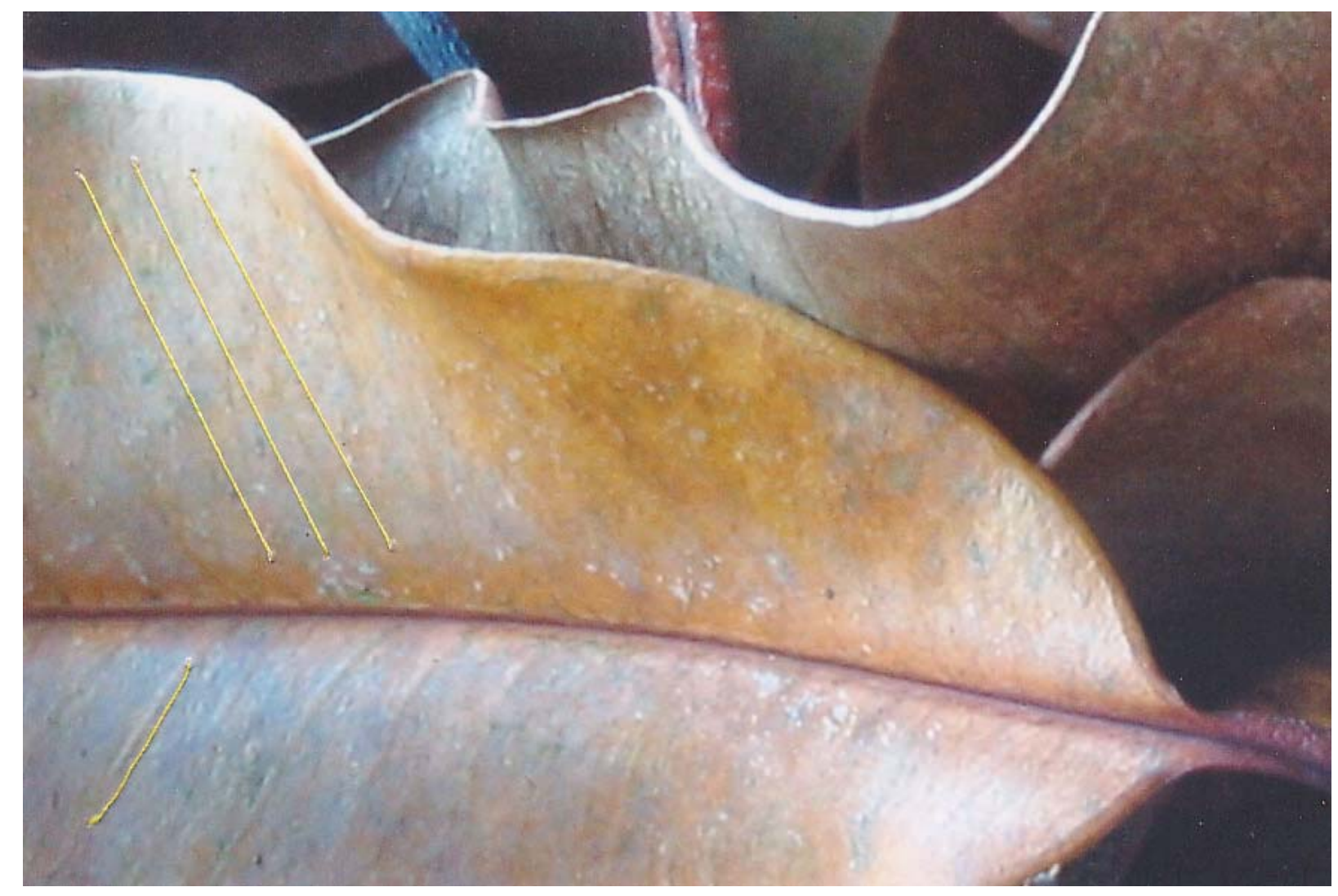




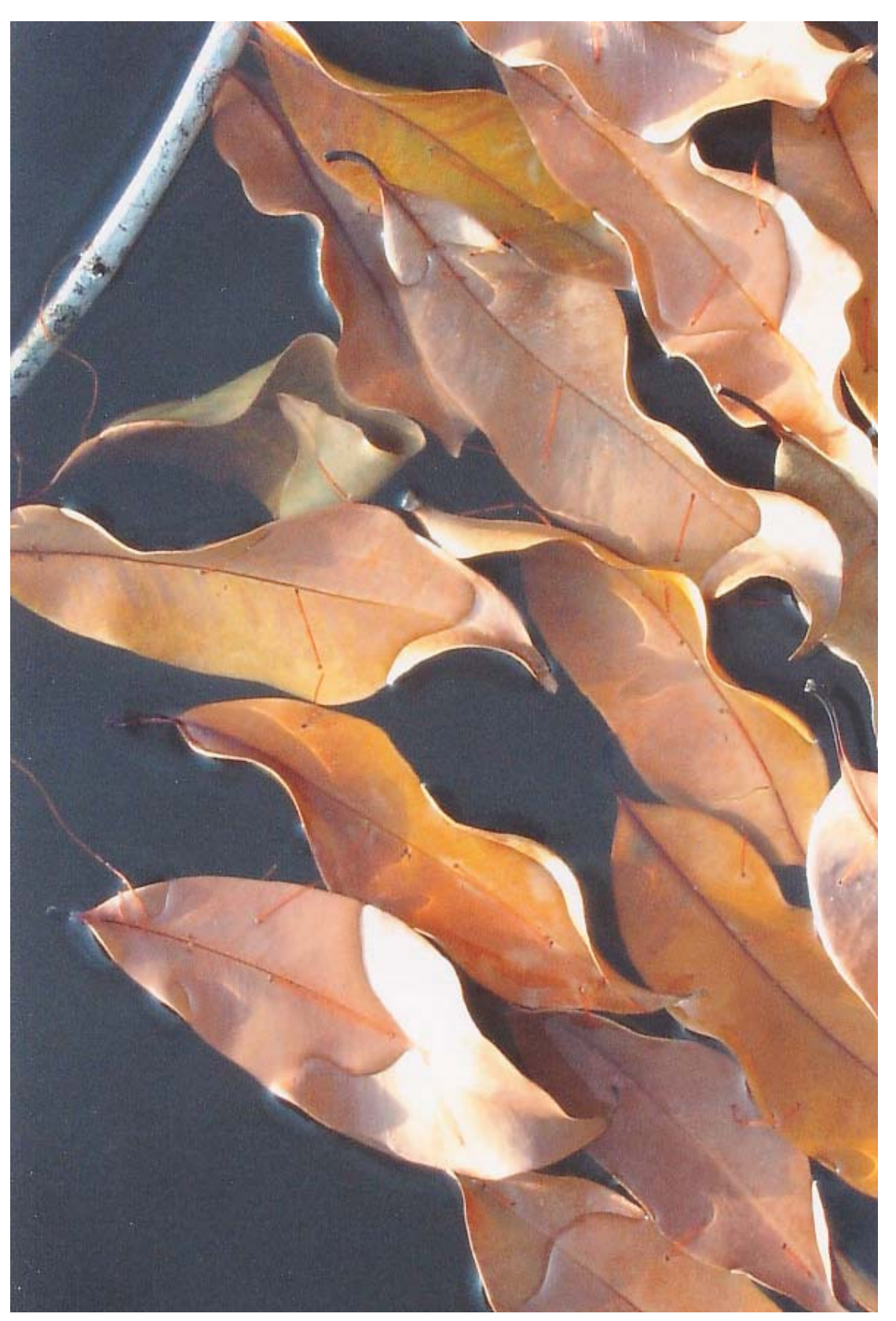




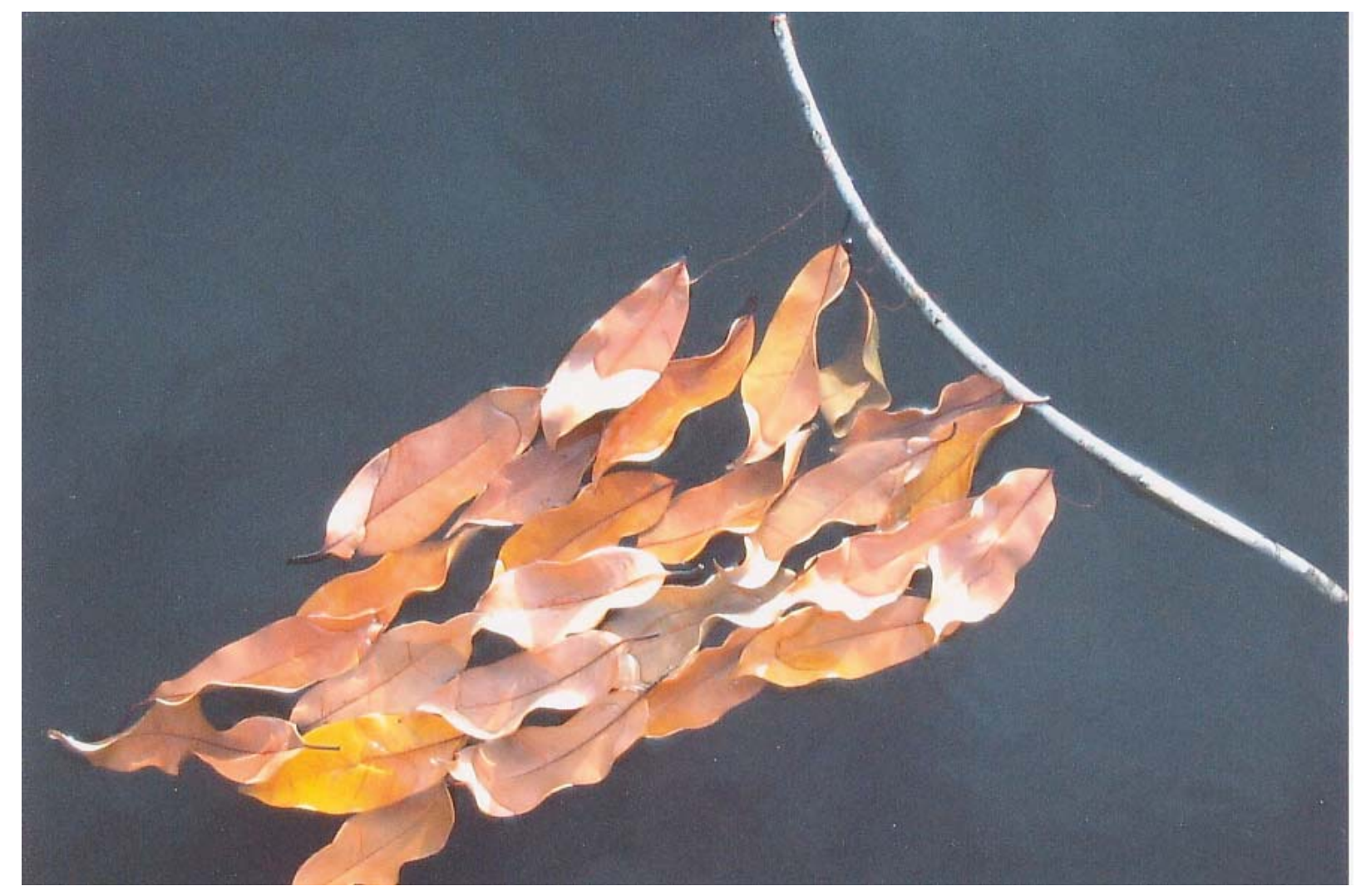




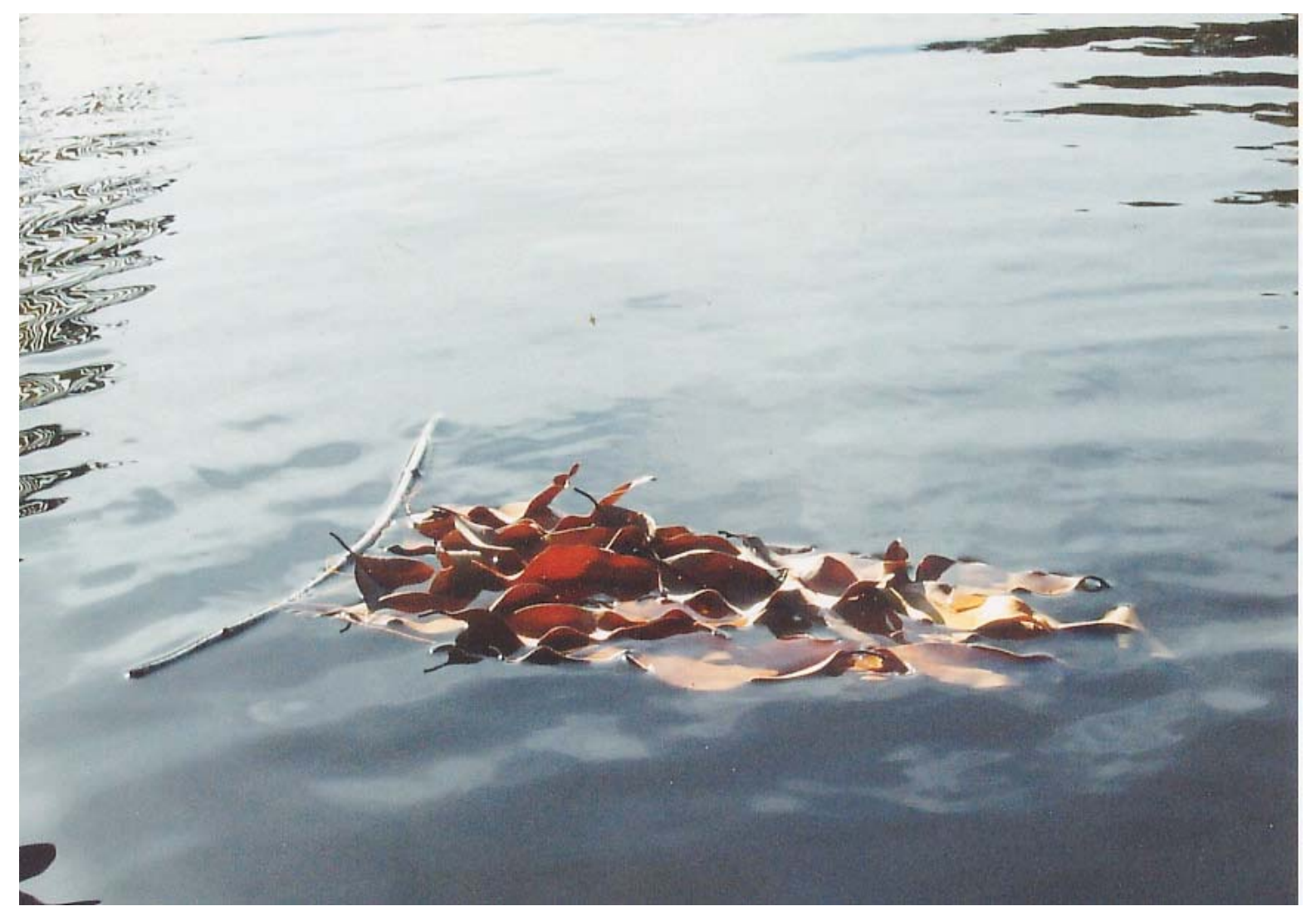




\section{3-Asas}

A produção plástica que se seguiu incorporou elementos desses questionamentos, a começar pela própria cerâmica, que traz em si vários desses paradoxos: é uma matéria plástica, frágil, que por meio da queima se transforma em matéria rígida e resistente. Uma matéria que permite o movimento e o aprisiona em um dos seus momentos, deixando nele as marcas do fazer.

Aqui a cerâmica se aproxima da fotografia: ambas trabalham com o tempo. Um tempo que é congelado, um fragmento de tempo. Para a fotografia, esse tempo tem a duração de um instante. Para a cerâmica, esse espaço de tempo é um pouco maior, um tempo em que a matéria é conformada e vai lentamente fixando essa forma por meio da perda da plasticidade, resultante da secagem e posterior queima.

Katsuko Nakano afirma em sua tese "Terra, Fogo, Homem" que "todas as matérias possuem um certo destino, uma certa vocação formal. No caso do barro, a plasticidade, a consistência, o peso, é que provocam, limitam e desenvolvem as formas(...)"11 Em minha poética, venho trabalhando a cerâmica bem próxima a esse limiar, explorando os limites do material. Ao trabalhar asas em cerâmica fica claro esse desafio: a terra, vista como uma matéria bruta, pesada, é retirada do

${ }^{11}$ NAKANO, 1988: 66 
chão e levada para o ar, ganhando uma conotação de suavidade e leveza, algo que na aparente fragilidade consegue garantir sustentação.

Mudando a matéria em sua espacialidade, esta ganha um outro conjunto de relações, de interações, de referenciais e passa a ser percebida de forma diferente, revelando sua indeterminação.

Um trabalho que me serve de referencial é o de lole de Freitas, que trata muito bem essas questões. Marcio Doctors analisa os aspectos de peso e leveza na obra de lole:

"O que the interessa do ponto de vista plástico é o poder dar forma ao momento em que a matéria pode ser o contrário de si mesma, pode ser outra imagem. A matéria que tende ao peso pode ter a visibilidade da leveza do ser. O que quer explicitar é o momento da transitoriedade em que podemos surpreender a matéria em sua pulsão mais vital, que é a mudança; que é a de entrar e sair da realidade; que é a de entrar e sair do mundo das imagens."12

No caso das asas de cerâmica, além da transitoriedade referente ao peso e leveza, existe ainda uma outra referente à mudança que a própria matéria sofre, quando através da passagem pelo fogo deixa de ser uma coisa - terra - para ser outra - cerâmica - explicitando suas possibilidades de transmutação.

No primeiro trabalho da série "Vôo", a intenção de construir corpos espacializados, desprendidos do plano começa a se concretizar. O objeto se desloca do plano, mas possui ainda uma natureza transitória. A imagem transforma-se num corpo no espaço, a escultura desloca-se da superfície da parede, mas ainda a mantém como referencial direto - é nela que a obra se

${ }^{12}$ FREITAS, 2001: 38 
sustenta. O trabalho repete ainda a forma desse plano - é um plano deslocado do outro. O trabalho é feito para uma visão frontal ou no máximo diagonal, como é próprio da pintura e da fotografia.

Esse primeiro trabalho, intitulado "Criando asas" foi construído a partir de lâminas de cerâmica esmaltadas presas por meio de um fio metálico a uma estrutura metálica, que traça a linha superior do desenho da escultura. Essa estrutura é fixada à parede, mantendo dela um afastamento de $15 \mathrm{~cm}$, gerando um duplo em sua sombra. 
Fig. 19

'criando asas', 2002

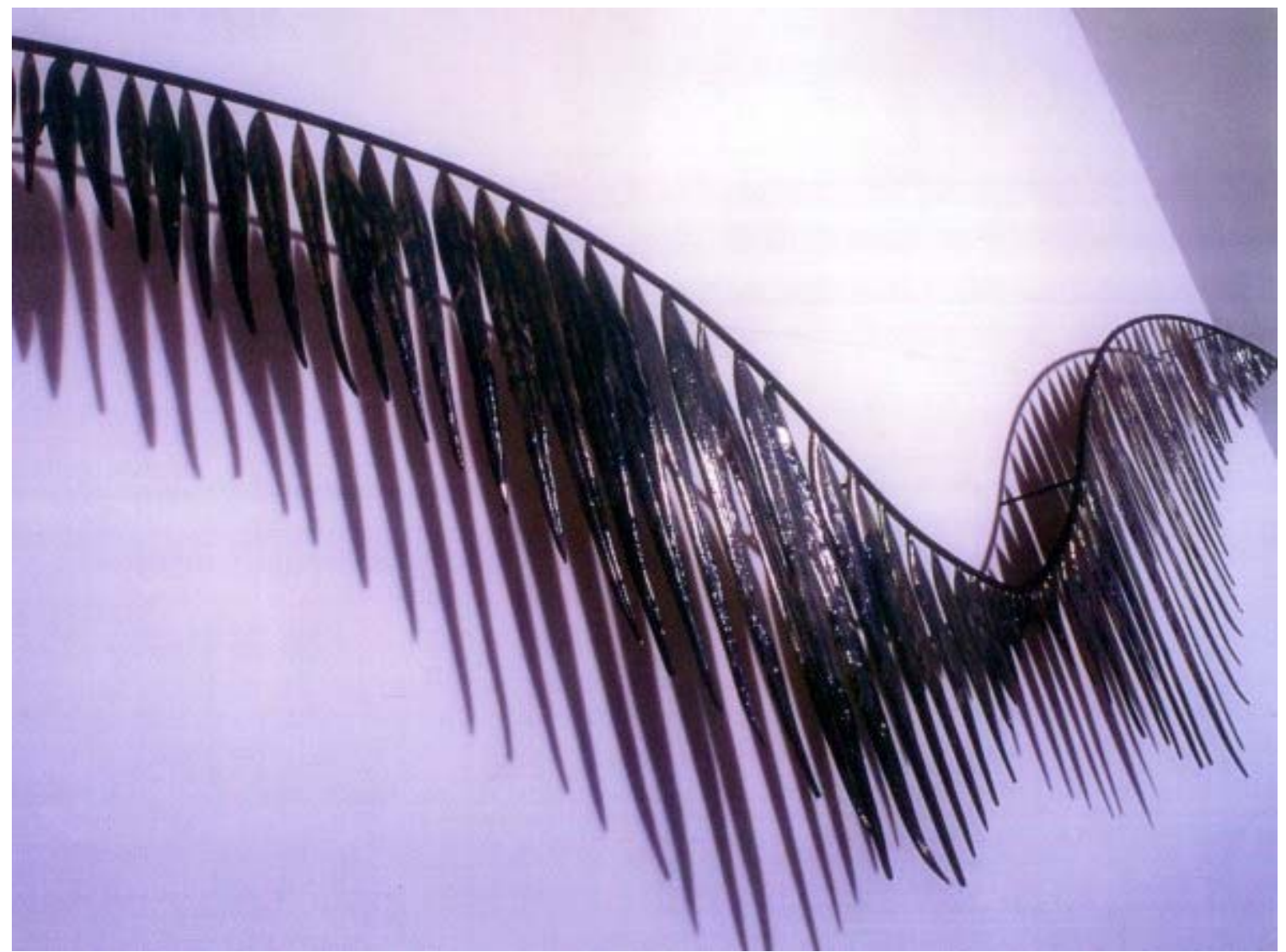


Fig. 20

Detalhe 'criando asas', 2002

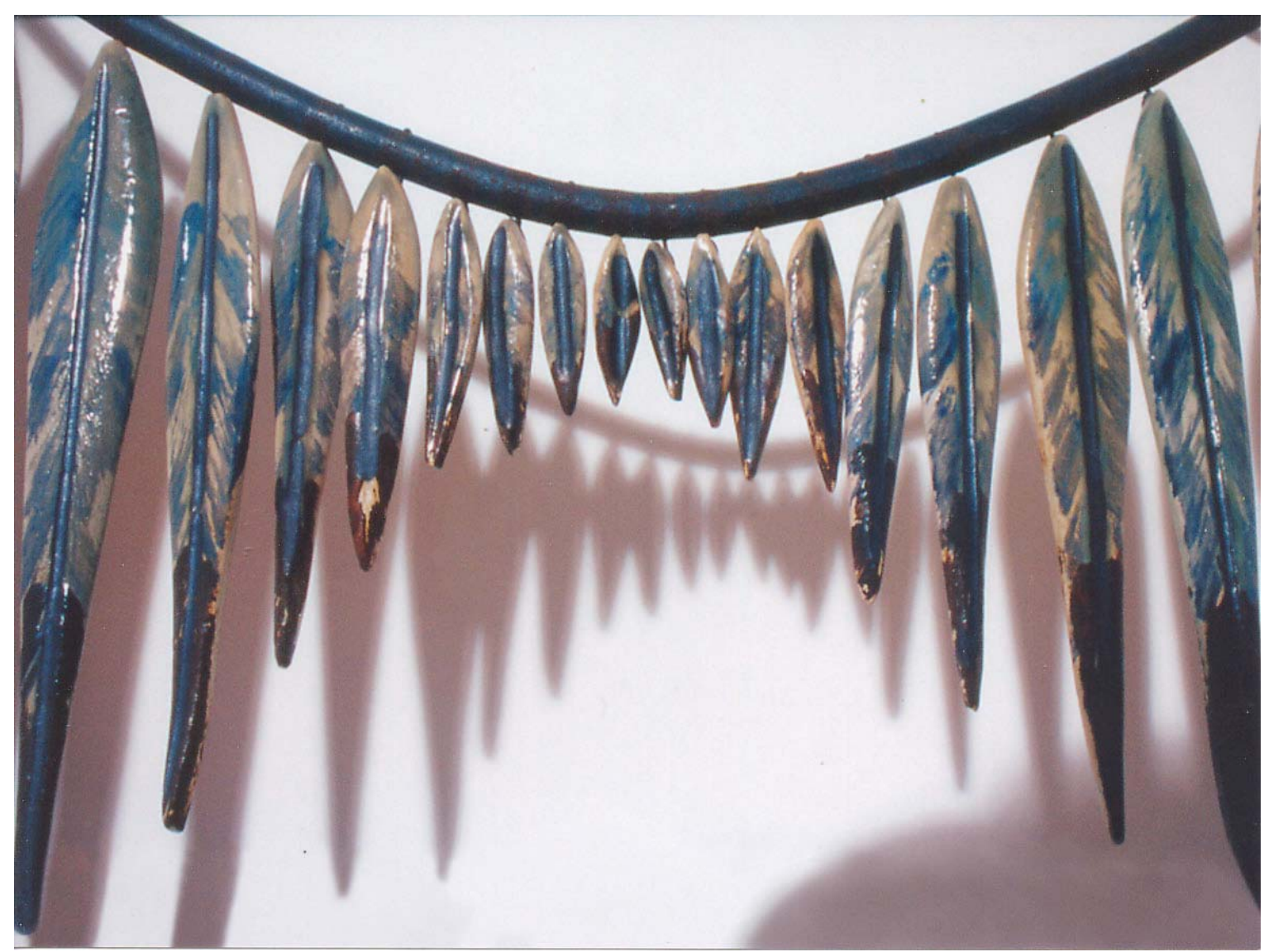




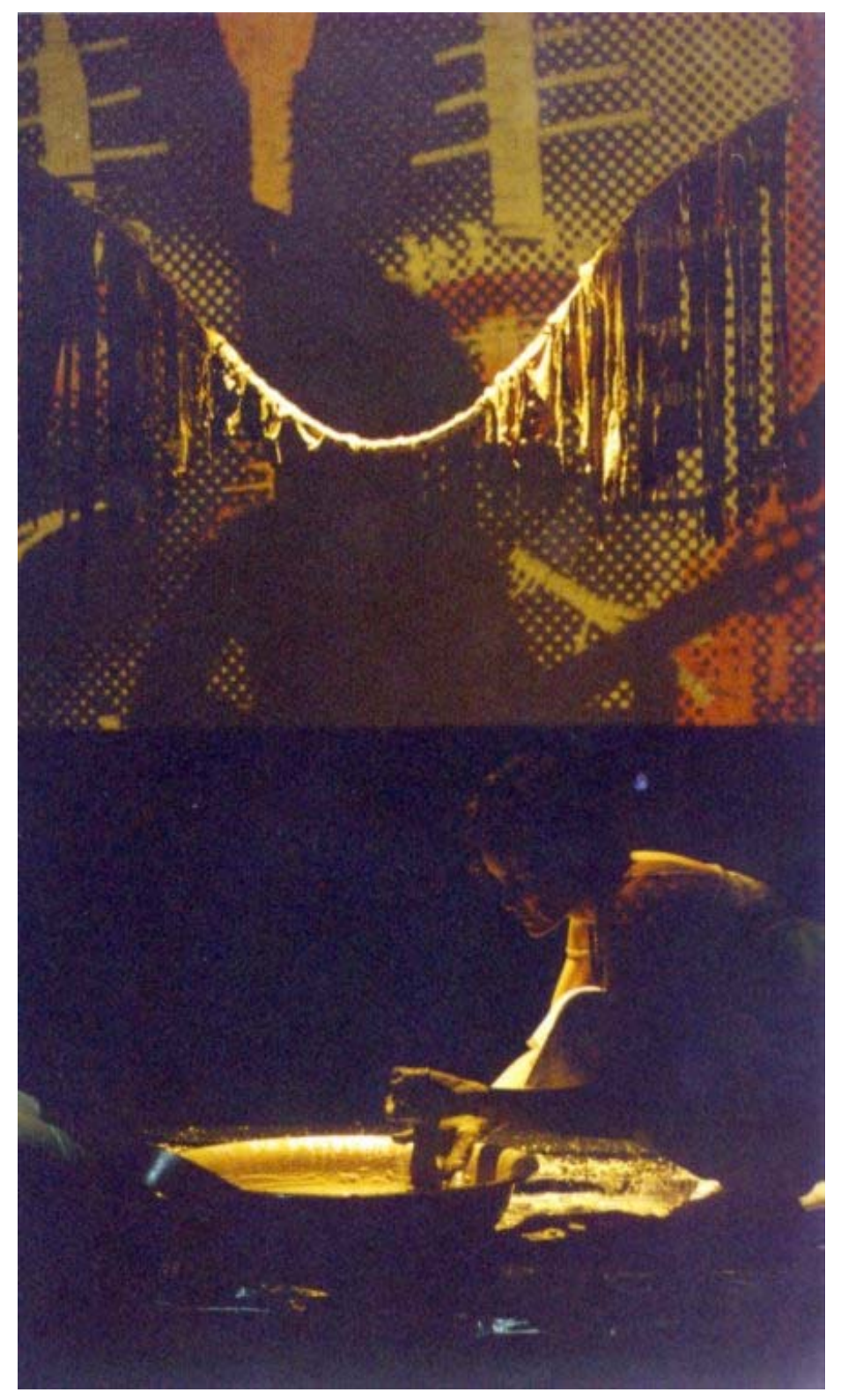

No trabalho seguinte, uma estrutura semelhante é construída, mantendo ainda uma conformação de plano, mas desta vez desprendida do suporte da parede. O trabalho agora flutua no espaço, fixado por fios presos ao teto. Esse trabalho foi construído diante do público, numa performance de contrução de uma asa, em que tecidos brancos eram rasgados e mergulhados em argila líquida, resultando numa forma desconstruída do trabalho anterior. A imagem fotográfica se faz presente numa projeção que atravessa o trabalho. Aqui, o duplo de sombra se forma na parede de fundo, interferindo nas imagens fotográficas projetadas.

Nessa mesma relação estabelecida com a terra que quer ganhar o ar, construí pequenas asas de barro, que não passaram pela queima, a partir de asinhas para crianças, montadas com penas, dessas encontradas em qualquer armarinho, que me recordavam as procissões de Corpus Christi na minha infância. Essas asinhas eram mergulhadas em argila líquida e presas à parede como se fixam as asas de borboletas, espetadas com alfinetes. Esse trabalho se refere à perda da inocência infantil, da pureza que, mais cedo ou mais tarde, é deixada para trás. Remete aos momentos em que os sonhos mais puros de vôo são abandonados.

Mais adiante, passei a trabalhar com formas em porcelana branca, sem esmaltação, que trazem nas lâminas o gesto de um corte rápido e assimétrico,

Fig.21

'construção de uma asa', performance, 2003. 
numa movimentação que não havia nos trabalhos anteriores. Apesar de já trabalhar com porcelana, ainda não havia conseguido o corpo translúcido desenvolvido em seguida. Esses trabalhos apresentavam lâminas grossas e gestuais. Em alguns trabalhos, a forma simétrica deu lugar a um gesto único, desenhado também por meio de uma estrutura metálica fixada à parede. ।

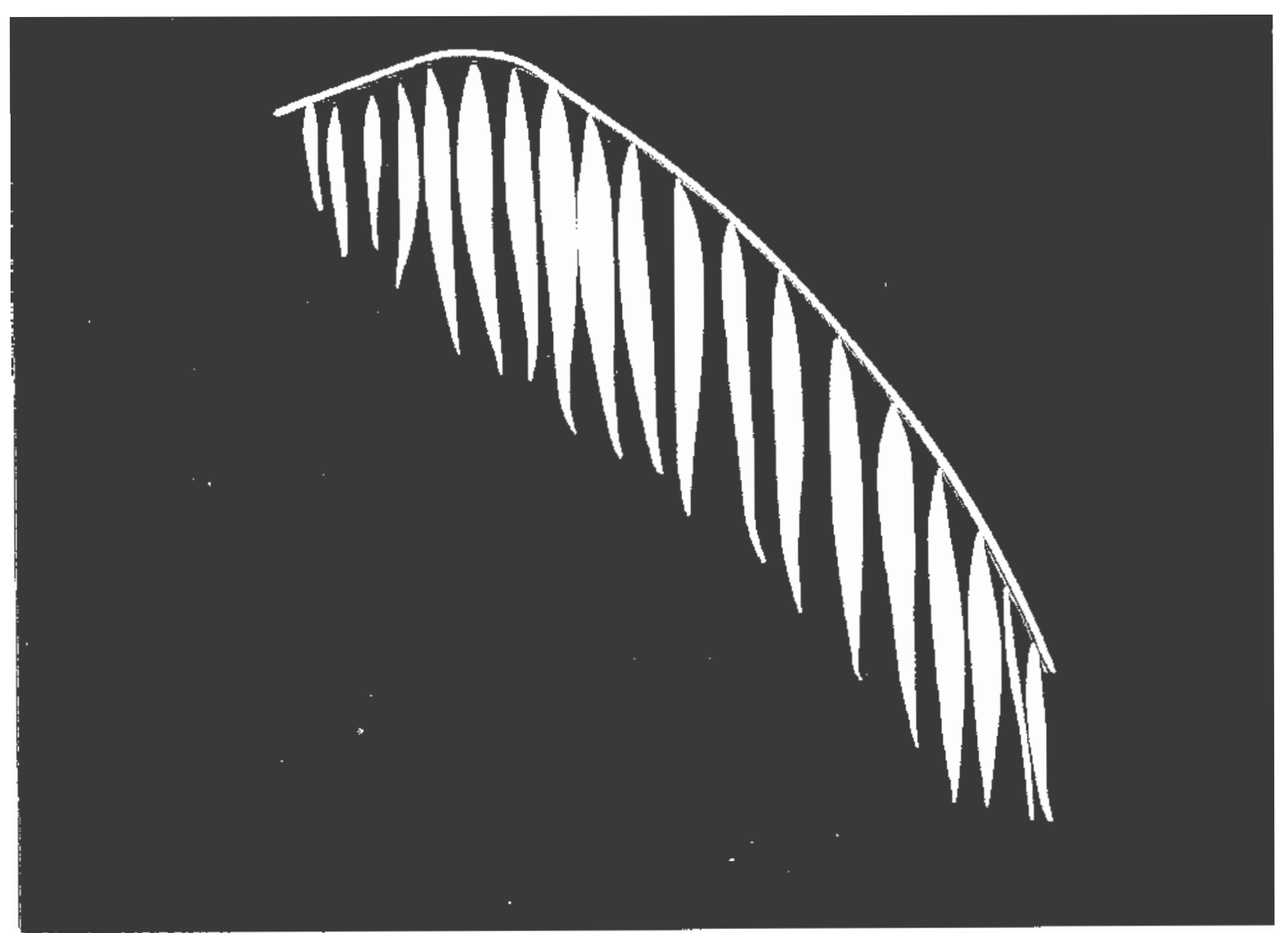


Esses trabalhos fazem referência às possibilidades de transmutação, metamorfose, de transformação das coisas pesadas em leves. Revelam a possibilidade de construção das próprias asas, asas humanas, da própria liberdade, da possibilidade de voar, o desejo de vôo, meio à maneira de Ícaro.

Esses trabalhos em porcelana foram concebidos em julho de 2003, durante o mês que passei na Casa do Artista, no Mosteiro Zen Morro da Vargem, em Ibiraçu, ES. Esse é um lugar especial, que permite ficar em silêncio. Foi um tempo muito significativo na minha vida e muito importante na concepção do meu trabalho. 


\section{4 - Leveza - nuvens}

"As únicas coisas eternas são as nuvens." Mário Quintana

No início deste trabalho, fiquei entre Vitória e São Paulo, fazendo vôos constantes, duas vezes por semana. Da construção das asas passei efetivamente a voar... Esses deslocamentos me inquietavam muito. Depois de vários meses, tive a sensação de não estar mais em lugar algum, uma sensação de não pertencimento. Nesse período, comecei a prestar muita atenção às nuvens. Segundo Nelson Brisac Peixoto "Paisagem é o lugar dos que não tem lugar"13. Inquietava-me muito ver as nuvens em sua fluidez e transitoriedade. Comecei a vêlas como desenhos impermanentes ou desenhos da impermanência e da leveza. As nuvens são matéria sem densidade e sem rigidez, em movimento e transmutação constante, uma mescla de transparência e opacidade.

Meu interesse foi crescendo e, em meu trabalho, comecei a sentir a necessidade de criar em cerâmica corpos muito leves, translúcidos. Buscava uma matéria que pudesse aliar a aparente leveza à força necessária à sua sustentação no mundo. O trabalho desenvolvido se colocaria no limite entre sustentável e insustentável. A cerâmica já é em si uma matéria repleta de forças e fragilidades. É um corpo mutante, repleto da relação entre infinitas possibilidades e alguns limites.

${ }^{13}$ PEIXOTO, 1996: 26 
Por meio da secagem e da queima, uma matéria amorfa - a argila - é aprisionada em um de seus instantes. Comecei, então, a pensar nesse corpo muito leve, translúcido, quase imaterial, um corpo que fosse o desenho ou a fotografia de um instante de impermanência das nuvens.

Iniciei minhas experimentações no desenvolvimento de uma matéria adequada, com as qualidades expressivas que 0 trabalho requeria. Escolhi trabalhar a porcelana por ser uma matéria que apresenta muita resistência e dureza, mesmo em corpos muito finos, além de possibilitar o desenvolvimento de uma matéria translúcida.

O translúcido possibilita a imersão na superfície. O olhar se volta para a profundidade do corpo. Junto com a luz, o olhar pode penetrar a superfície-corpomatéria. A translucidez é a possibilidade do olhar adentrar a matéria junto com a luz, quase atravessá-la.

Para o desenvolvimento desse corpo translúcido foi necessária uma pesquisa rigorosa e, por meio dela, elementos fundamentais em sua materialidade, visualidade e reflexão foram incorporados ao trabalho. 


\section{5 - Em busca de um corpo para o trabalho}

Existem diferentes classes de argilas, que estão relacionadas às condições geológicas atuantes em sua formação. Essas condições acarretam argilas de diferentes composições químicas e estruturas físicas. Um dos tipos de argila de grande interesse e principal componente da porcelana translúcida é o caulin ou argila da China. ${ }^{14}$

Contudo, para a produção de porcelana essa matéria precisa ser mesclada a outras, para abaixar seu ponto de fusão. O fundente empregado é o feldspato, que funde a uma temperatura de $1300^{\circ} \mathrm{C}$. Normalmente, também, adiciona-se quartzo para dar dureza e resistência à pasta e aumentar sua resistência à deformação. Pode-se, também, adicionar uma argila mais plástica para facilitar seu

\footnotetext{
${ }^{14}$ Este é um tipo de argila relativamente escasso na natureza, encontrado principalmente na Ásia, Europa e América do Norte. Segundo Daniel Rhodes, pg. 29, cerâmicas produzidas com argilas brancas foram produzidas na China desde a Dinastia Han, 200 A.C. Já a produção de cerâmica vitrificada branca, com temperaturas próximas a $1200^{\circ} \mathrm{C}$ e a utilização do caulin como principal argila data na China pelo menos de 600d.C. Essa produção na europa data de 1000d.C. Na China se encontram os depósitos mais abundantes dessa argila e os caulins mais plásticos. Ao longo dos séculos os chineses foram desenvolvendo fornos de temperaturas mais altas e fazendo adições em suas argilas para aumentar a dureza, brancura e translucidez. Caulin é uma matéria prima de partículas grossas e por isso menos plásticas que as demais argilas. Porém, é livre de contaminação de outros minerais, tais como o ferro, e portanto mais refratária, ou seja, suporta temperaturas mais altas, podendo atingir $1800^{\circ} \mathrm{C}$. É trabalhado normalmente mesclado a outras matérias para melhorar sua plasticidade (capacidade de ser modelado) e alcançar dureza em temperaturas mais baixas.
} 
manuseio. A formulação exata depende da temperatura a ser utilizada e do tipo de matéria-prima disponível. ${ }^{15}$

Iniciei a pesquisa partindo das matérias-primas básicas, incluindo cinza de ossos. Essa composição foi preparada e queimada em forno elétrico a uma temperatura de $1250^{\circ} \mathrm{C}$. O resultado foi insatisfatório, pois devido a pouca plasticidade da massa, tornou-se fragmentada durante a secagem. A matéria resultante foi uma massa vítrea, mas nada translúcida.

Com a urgência para obtenção de uma massa adequada, optei por trabalhar com massas de porcelana prontas, transformando-as em barbotina (argila líquida) e misturando-as a uma carga de papel, resultando numa massa denominada paper-clay. Esse material, após a queima, resulta em um corpo mais poroso, facilitando a translucidez. O papel ajuda ainda a dar uma maior plasticidade à porcelana antes da queima, facilitando seu manuseio.

Experimentei massas de fornecedores diferentes, optando por uma porcelana importada por ter apresentado, após os testes, uma maior facilidade para a obtenção de translucidez. As cargas empregadas foram diversos papéis e fibra de vidro. O papel mais adequado foi à base de linter de algodão, uma fibra que fica entre o algodão e a semente. Esse papel tem ph neutro e não apresenta encolagens, facilitando o trabalho e proporcionando uma massa de melhor qualidade.

${ }^{15} \mathrm{Na}$ China a combinação de caulin, feldspato e cinza de ossos para controlar a temperatura de sinterização foram os principais segredos zelosamente guardados pelos ceramistas na confecção da porcelana translúcida. A plasticidade dos caulins chineses dispensa o uso de argilas mais plásticas na pasta. 
O papel deve ser picado e deixado de molho por pelo menos $24 \mathrm{~h}$. Deve ser batido em liquidificador industrial ou com um braço de batedeira adaptado a uma furadeira elétrica. A massa adicionada deve estar em forma líquida (barbotina), e neste caso, foi obtida a partir da massa deixada de molho e batida com os mesmos equipamentos.

Foram testadas diferentes porcentagens de papel de 2 a $20 \%$. A porcentagem adotada para os trabalhos seguintes foi de $10 \%$ de papel em $90 \%$ de porcelana seca.

Os testes foram realizados a uma temperatura de $1250^{\circ} \mathrm{C}$. A necessidade de trabalhar sempre com placas muito finas de argila torna 0 trabalho demasiadamente frágil. Para solucionar isso e obter um corpo fino, frágil ainda, mas com uma dureza maior, investiguei o uso de fibra de vidro adicionada à massa com papel. Obtive uma massa mais vítrea, extremamente leve, mas resistente e capaz de sustentar sua fragilidade.

Num primeiro momento, esse corpo foi trabalhado em placas planas, finas e lisas e serviram de suporte para as experiências fotográficas. No andamento do trabalho, surgiu a necessidade de construção de um corpo mais "flocado", mais tridimensionalizado. Após vários testes, esse corpo foi obtido colocando papel amassado sobre a placa de gesso, antes de depositar a barbotina para a secagem. O resultado foi um corpo não plano, flocado, mais interessante para a proposta da instalação. 
Fig.23

Experimentação de material

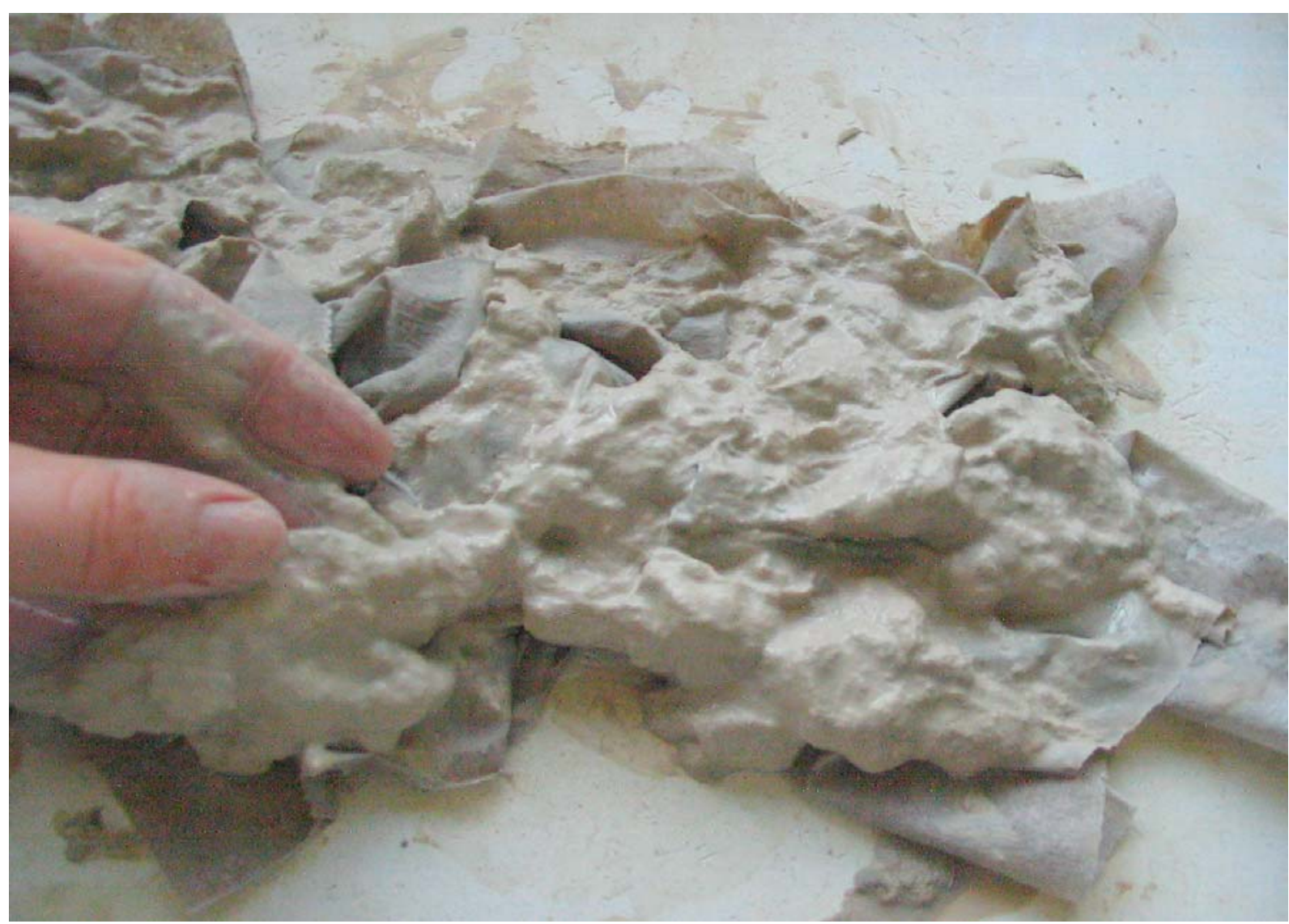


Fig.24

Construção do trabalho

'nuvens'

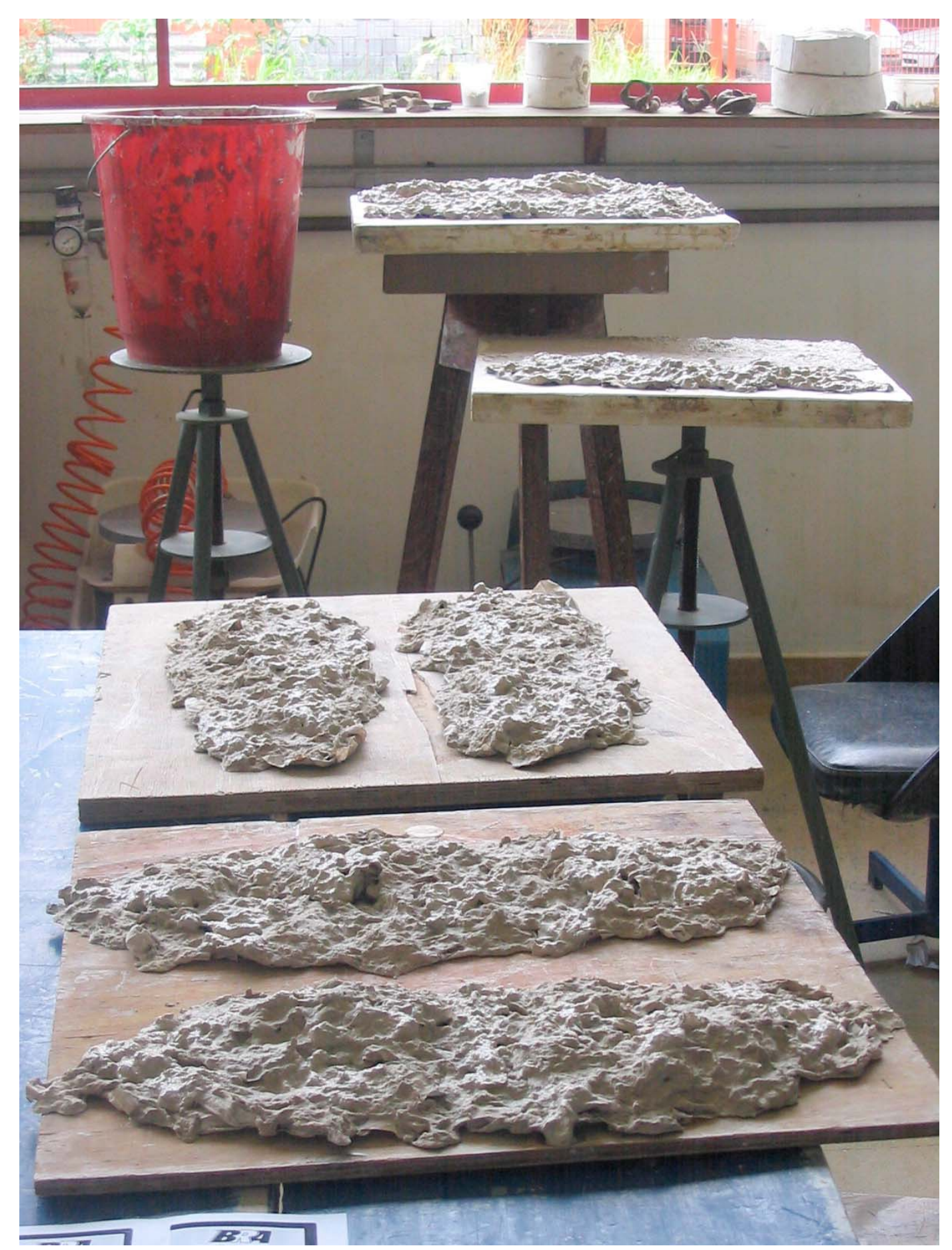




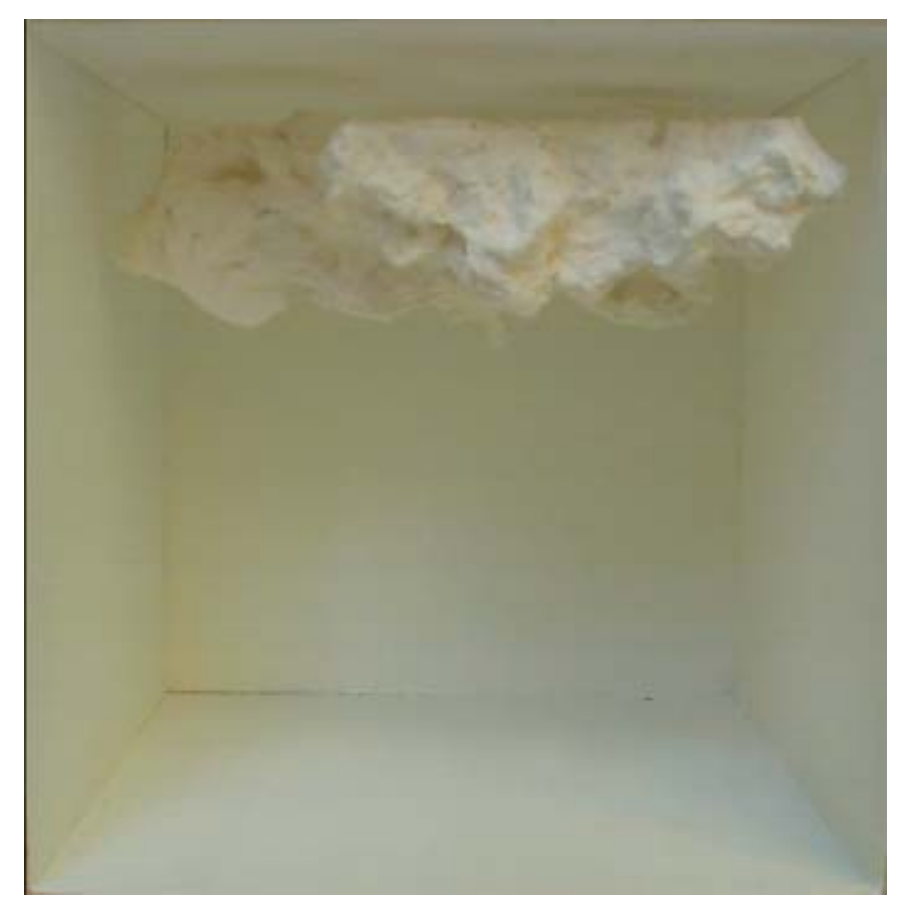

Fig. 25

Maquete instalação 'nuvens'

Fig. 26 e 27

'nuvens'
De posse desse corpo, pôde ser projetado o trabalho. Fiz, inicialmente, uma maquete que ajudou a solucionar a disposição espacial do trabalho, bem como sua forma de fixação.

Passei, assim, para a produção, que resultou em uma instalação e faz a ocupação do espaço superior. São elementos flutuantes, como nuvens, "quase" voláteis. Esse trabalho se diferencia dos anteriores pela perda da figuração direta, forma definida e contornos delimitados. Matéria e forma são uma coisa só, a matéria é desenho. $O$ trabalho é formado a partir do comportamento da matéria. Continua remetendo à relação entre o peso da matéria e a leveza em sua visualidade. Os corpos são suspensos por cabos metálicos finos.

Trabalho com o frágil. Busco a força presente na aparente fragilidade. Esse trabalho se aproxima das nuvens não em sua forma, em sua multiplicação, mas em sua leveza, seu silêncio, seu tempo e temporalidade próprios. Esse é um trabalho silencioso. Escuto seu silêncio. Seu movimento é leve, flutuante. Parece habitar um outro tempo, um tempo muito próprio, assim como as nuvens. 


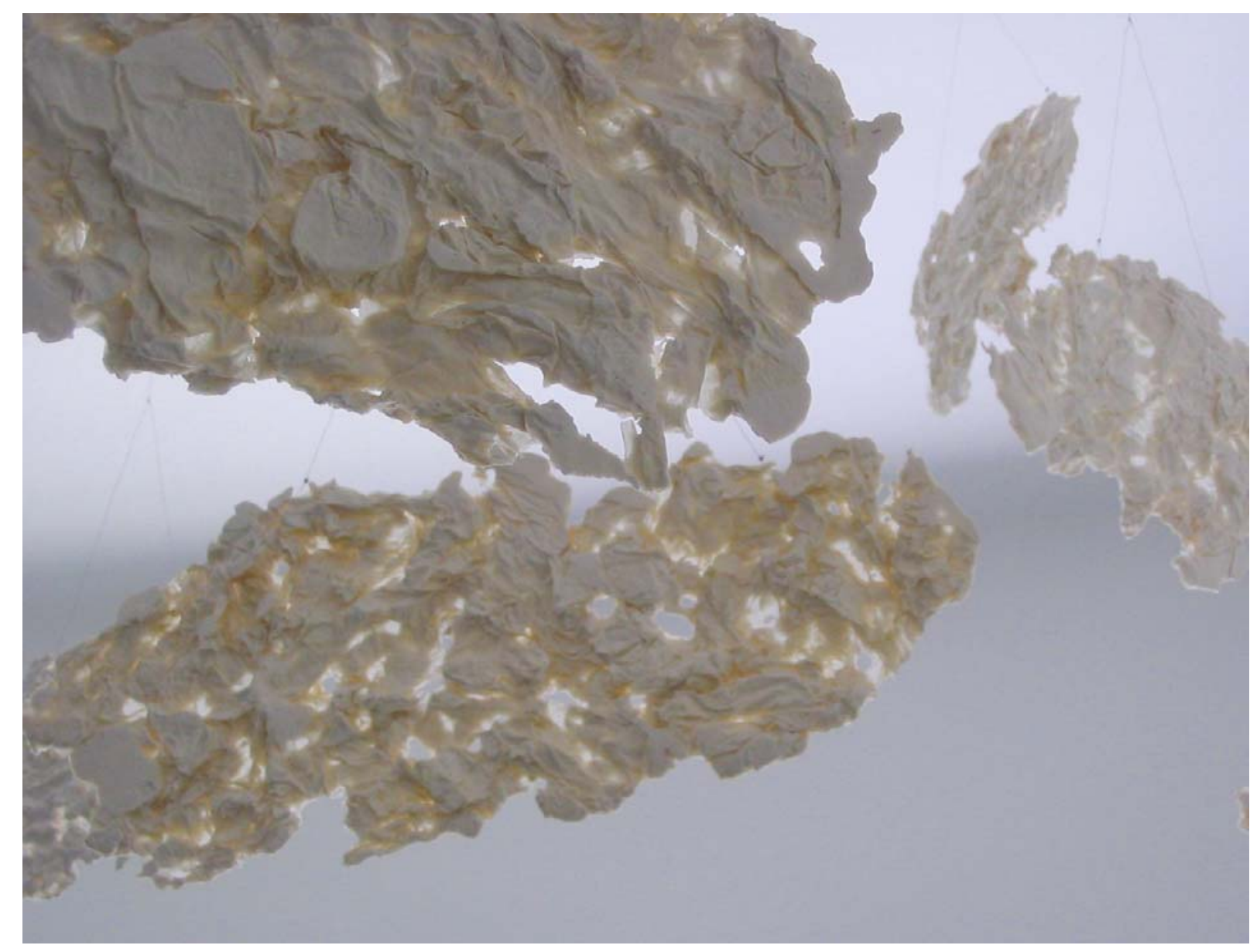




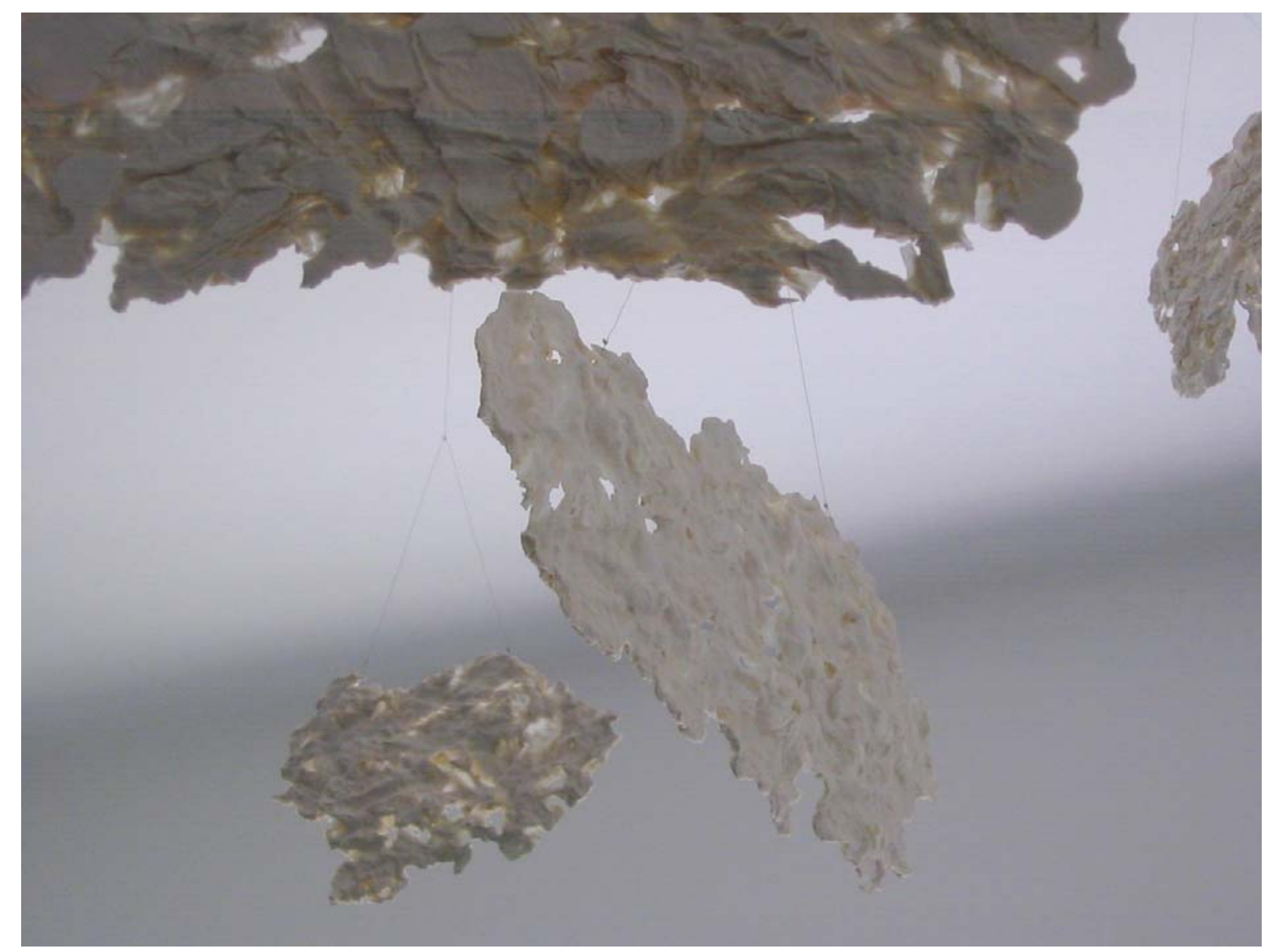


Fig.28

Instalação

Salão Nacional de Cerâmica

Curitiba, PR, 2006

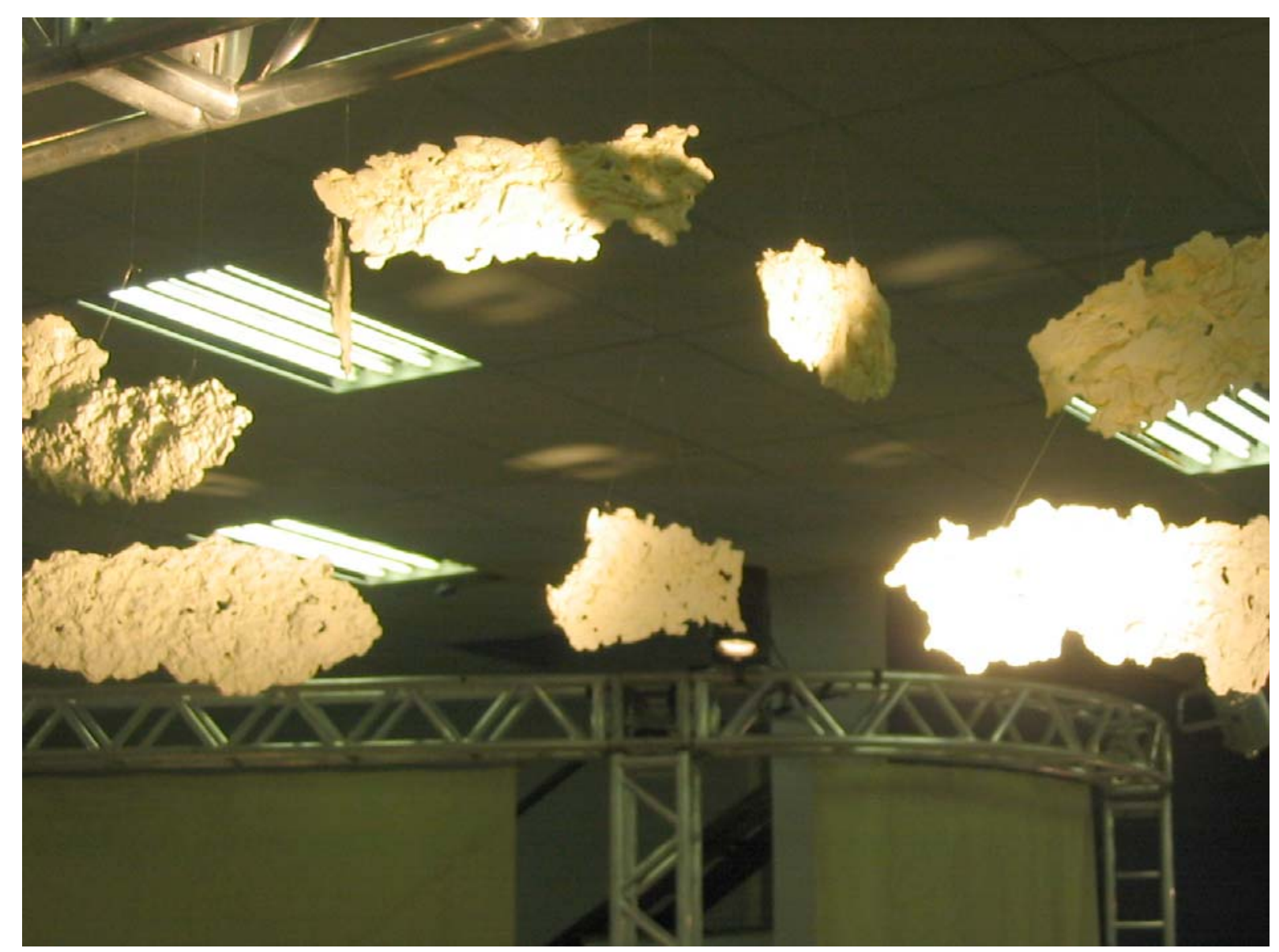


Esse trabalho foi desenvolvido e instalado no batistério da Capela do Morumbi, sendo uma das duas instalações que apresentei nesse espaço, em minha exposição individual em novembro de 2007, por ocasião da conclusão de minha pesquisa de mestrado.

Fig.29 e 30

Instalação 'nuvens'

Capela do Morumbi, 2007

Fig.31, 32 e 33

Detalhe

Instalação 'nuvens'

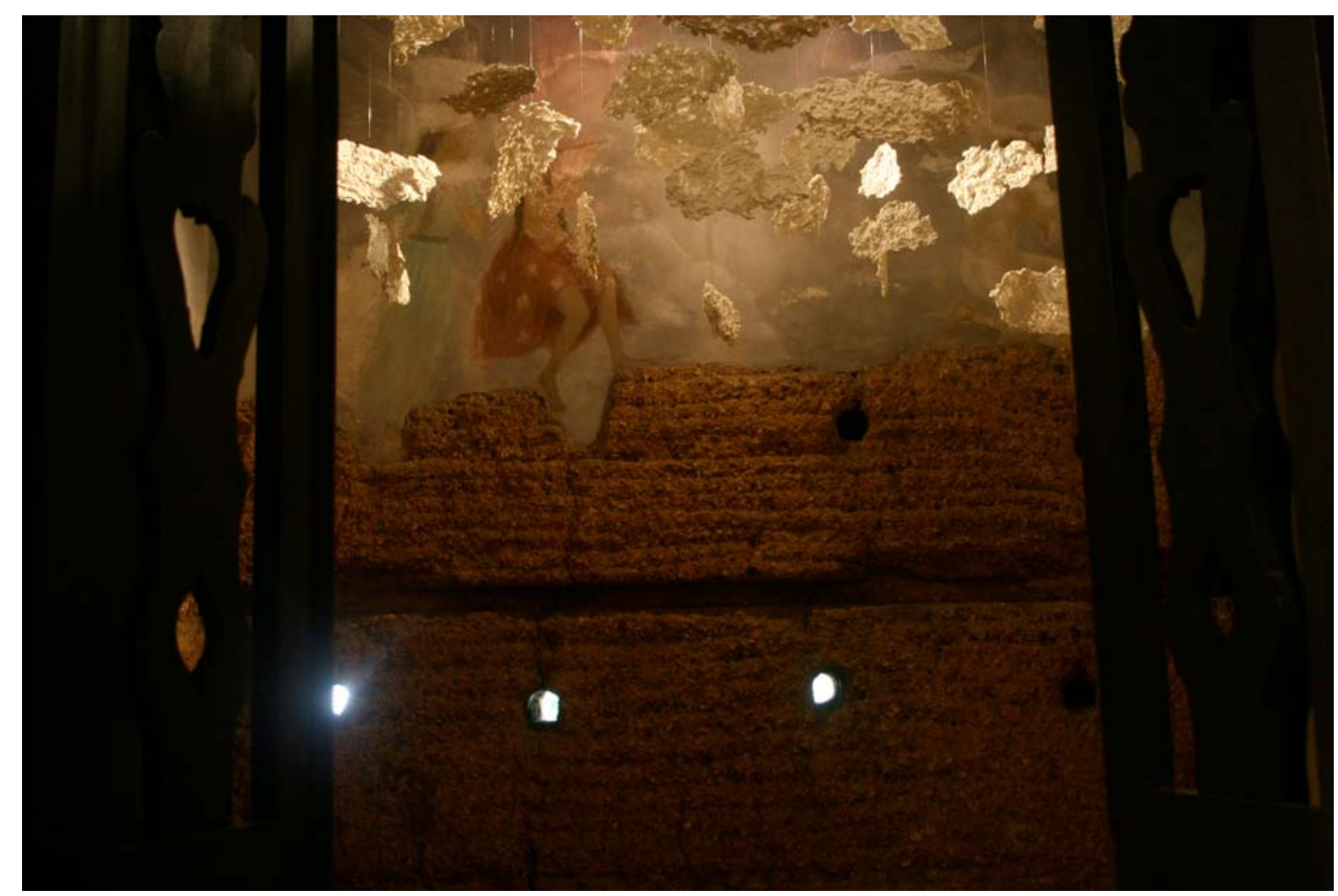




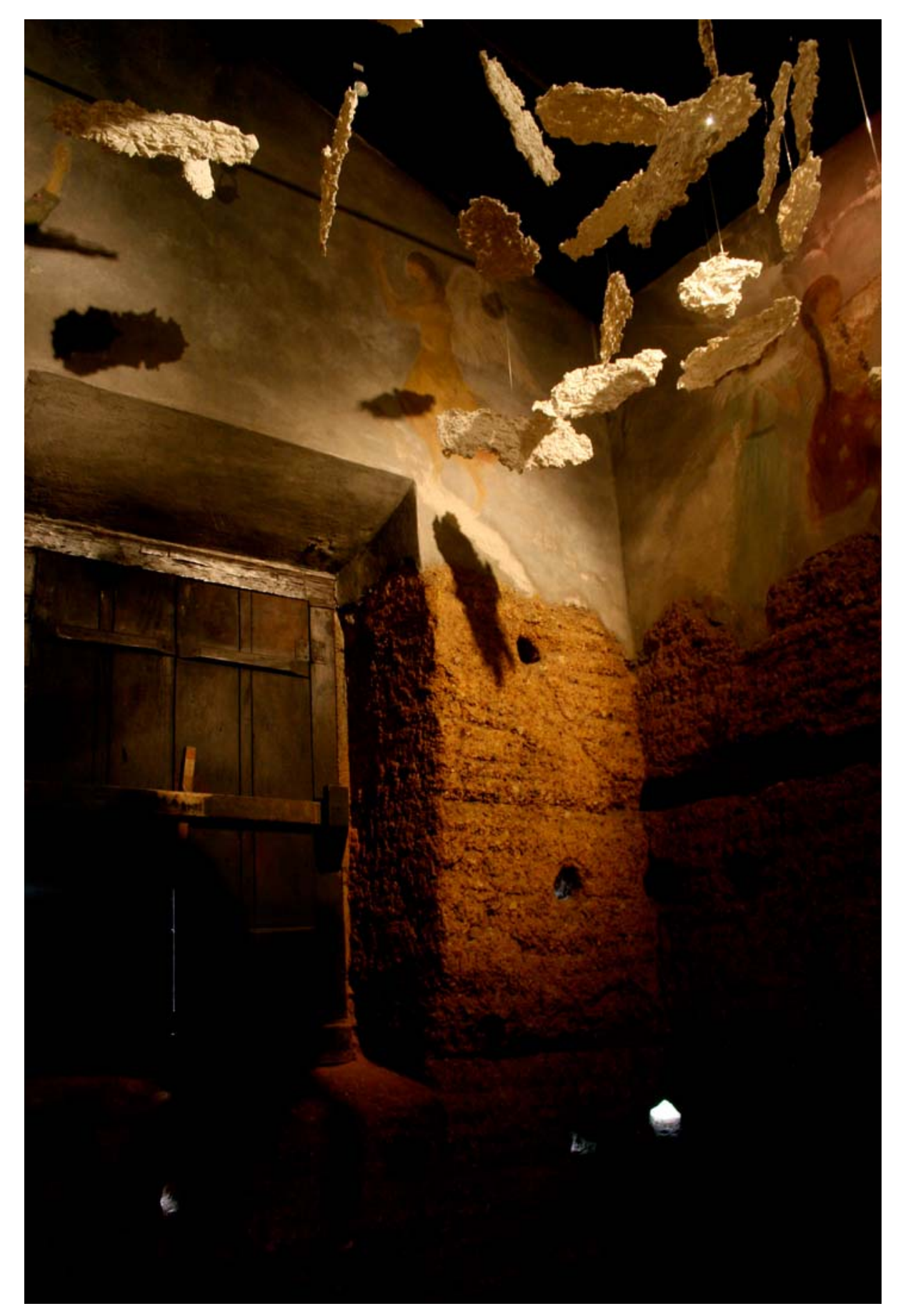




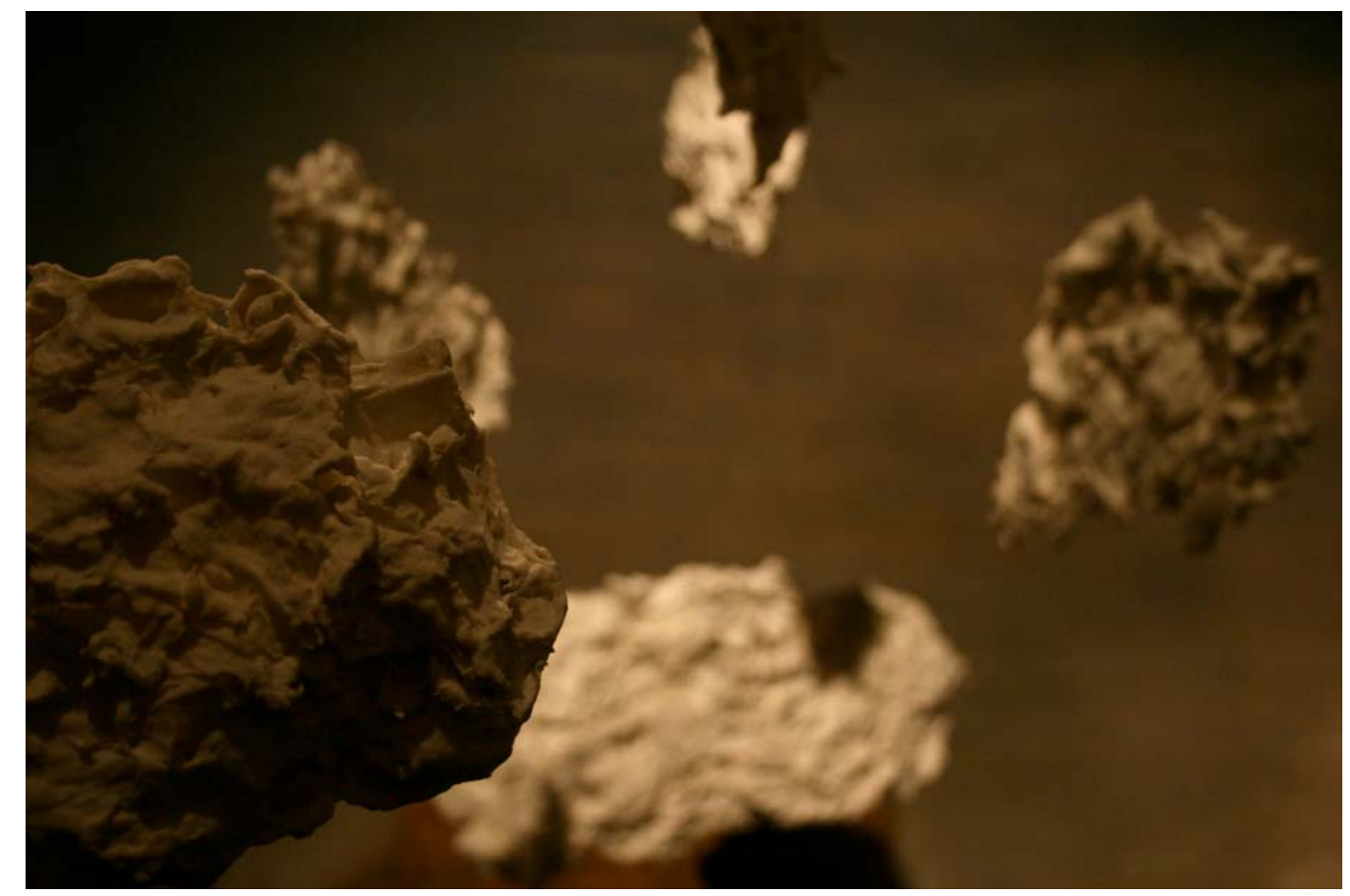




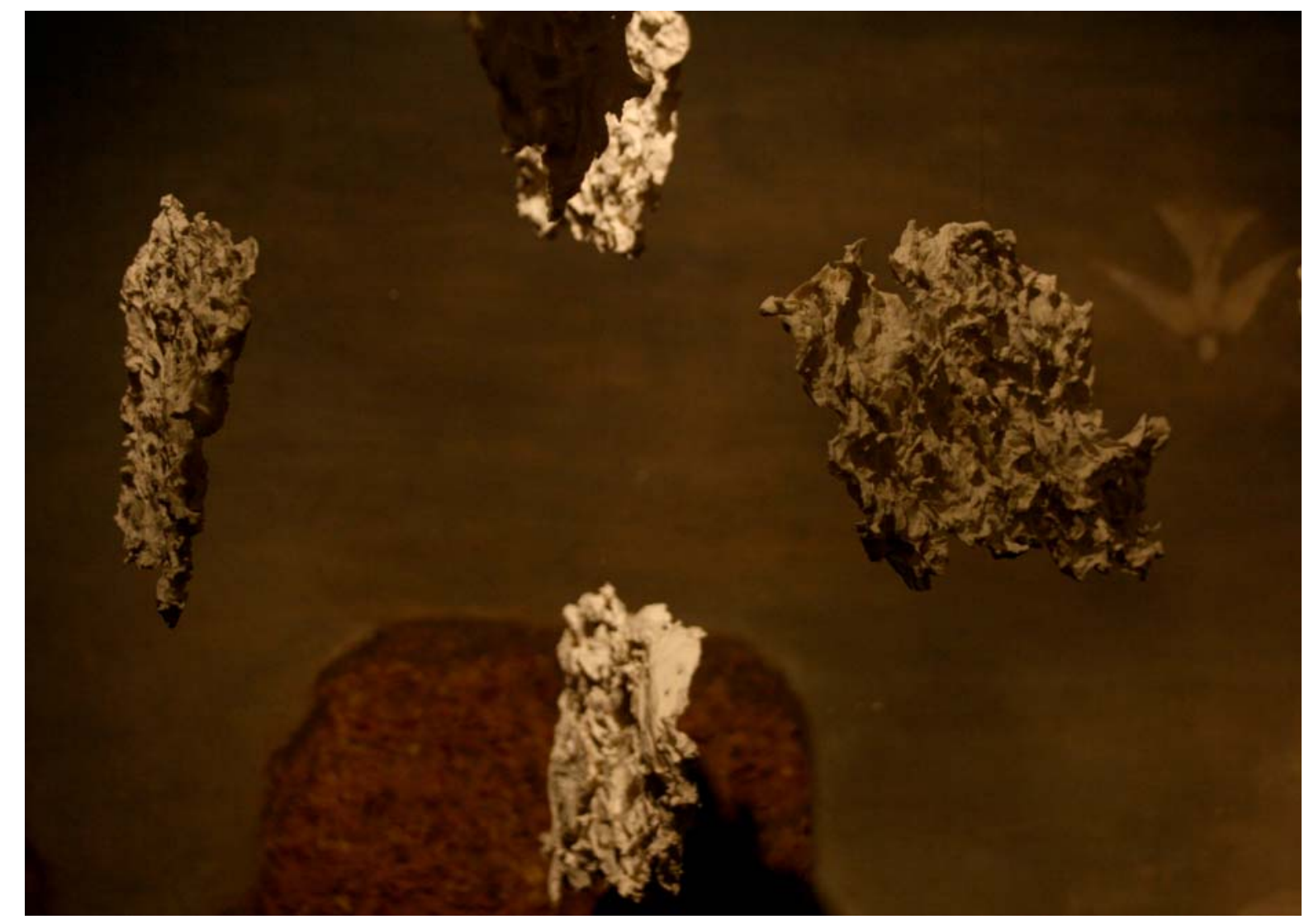




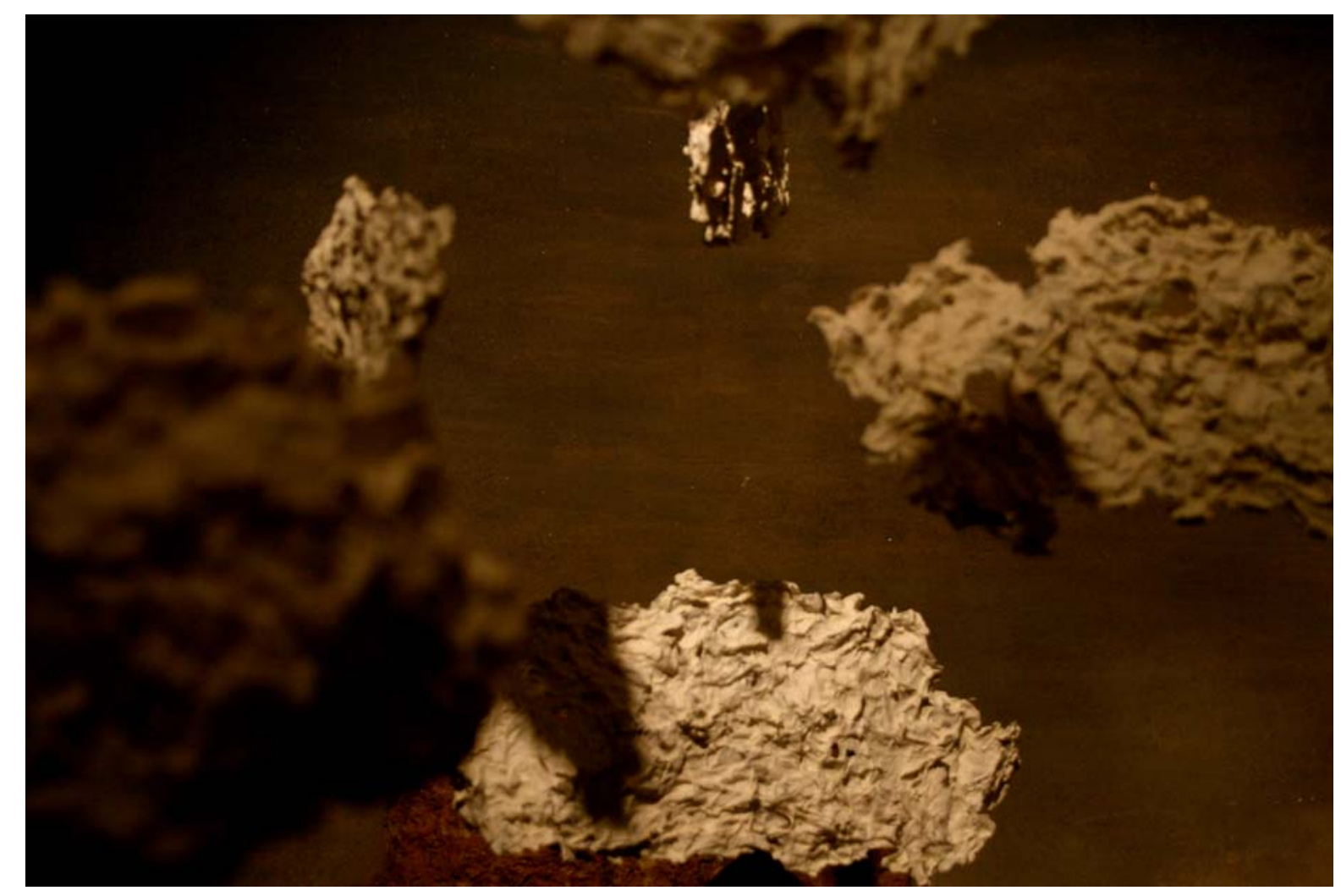




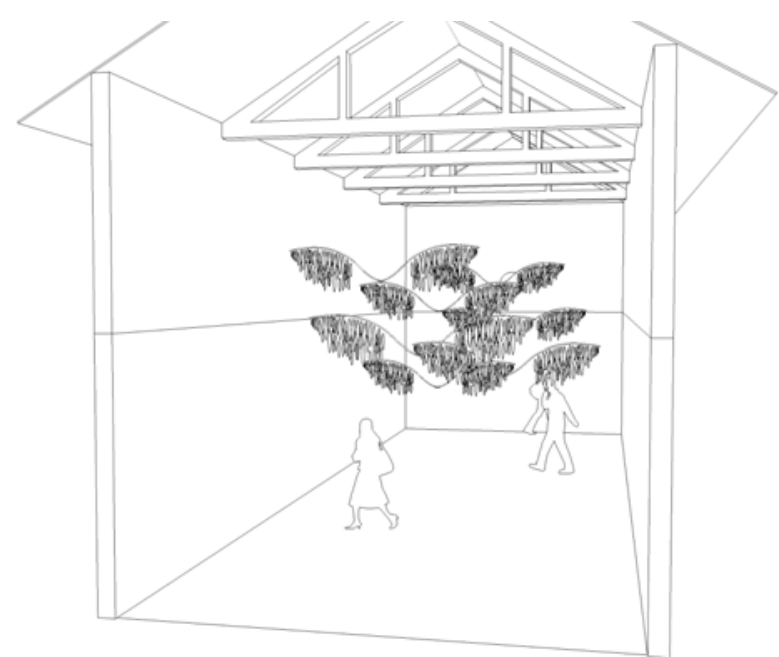

Fig.34 a 39

Projeto da instalação 'asas'
A outra instalação ocupou a nave central desse espaço e foi composta por asas suspensas, construídas a partir da porcelana translúcida desenvolvida. Nesses trabalhos, está concretizado o sentido de transposição, de inversão do peso em leveza, da matéria em imaterial, ao mesmo tempo, que é realizada uma passagem do invisível ao visível.

Sueli Rolnik afirma que o artista moderno decifra e atualiza os devires do mundo a partir de suas sensações e o faz na própria imanência da matéria e o artista contemporâneo leva essa virada ainda mais longe,

"indo além não só dos materiais tradicionalmente elaborados pela arte, mas também de seus procedimentos (escultura, pintura, desenho, gravura, etc.): ele toma a liberdade de explorar os materiais os mais variados que compõem o mundo, e de inventar o método apropriado para cada tipo de exploração.

Portanto, um dos aspectos do que muda e se radicaliza no contemporâneo é que a partir do momento que a arte passa a trabalhar qualquer matéria do mundo e nele interferir diretamente, explicita-se de modo mais contundente que a arte é uma prática de problematização: decifração de signos, produção de sentido, criação de mundos." ${ }^{16}$

Para Rolnik, a singularidade de cada artista está no "pedaço de mundo que escolhe obrar" e nos procedimentos que inventa para isso.

${ }^{16}$ ROLNIK, 2002 


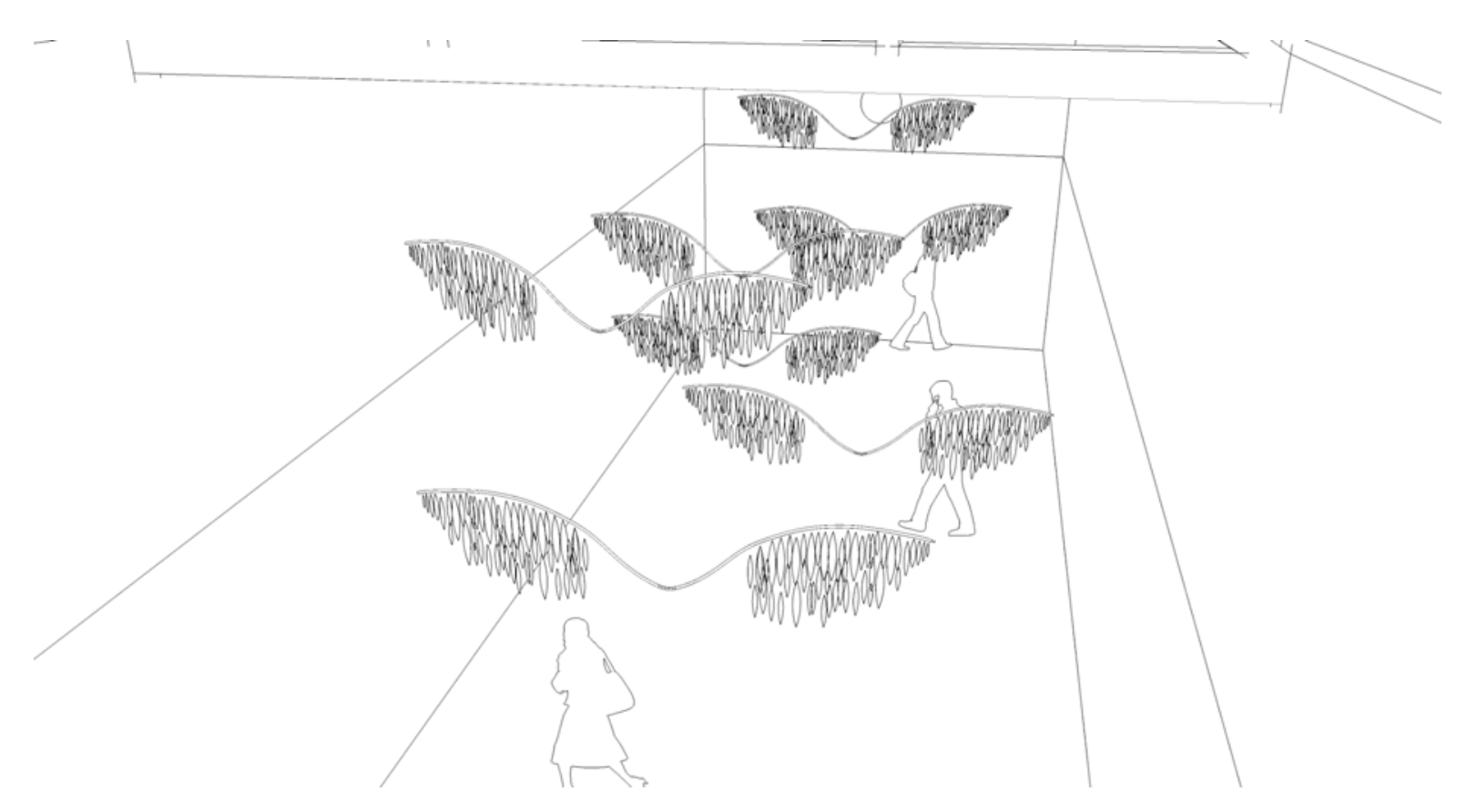




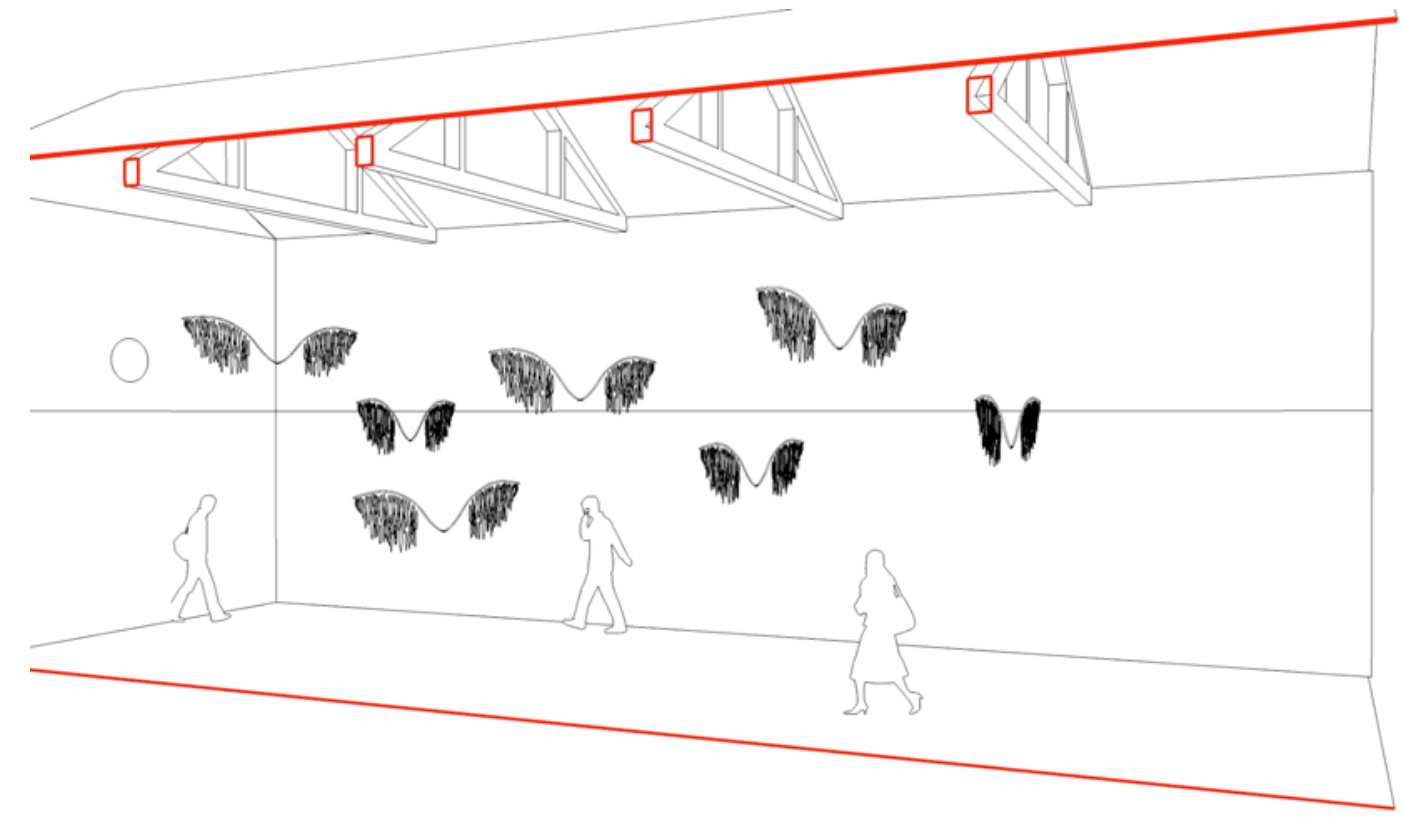




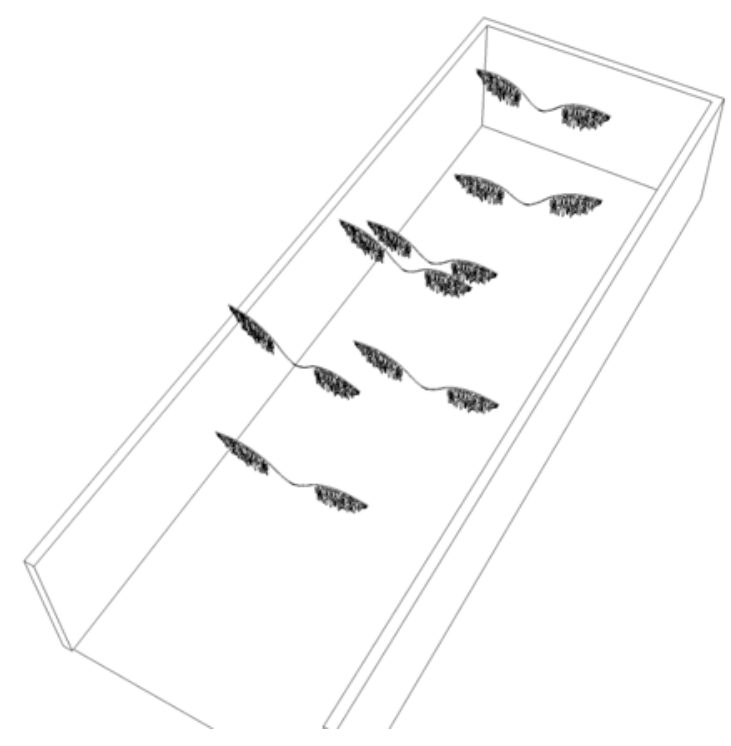




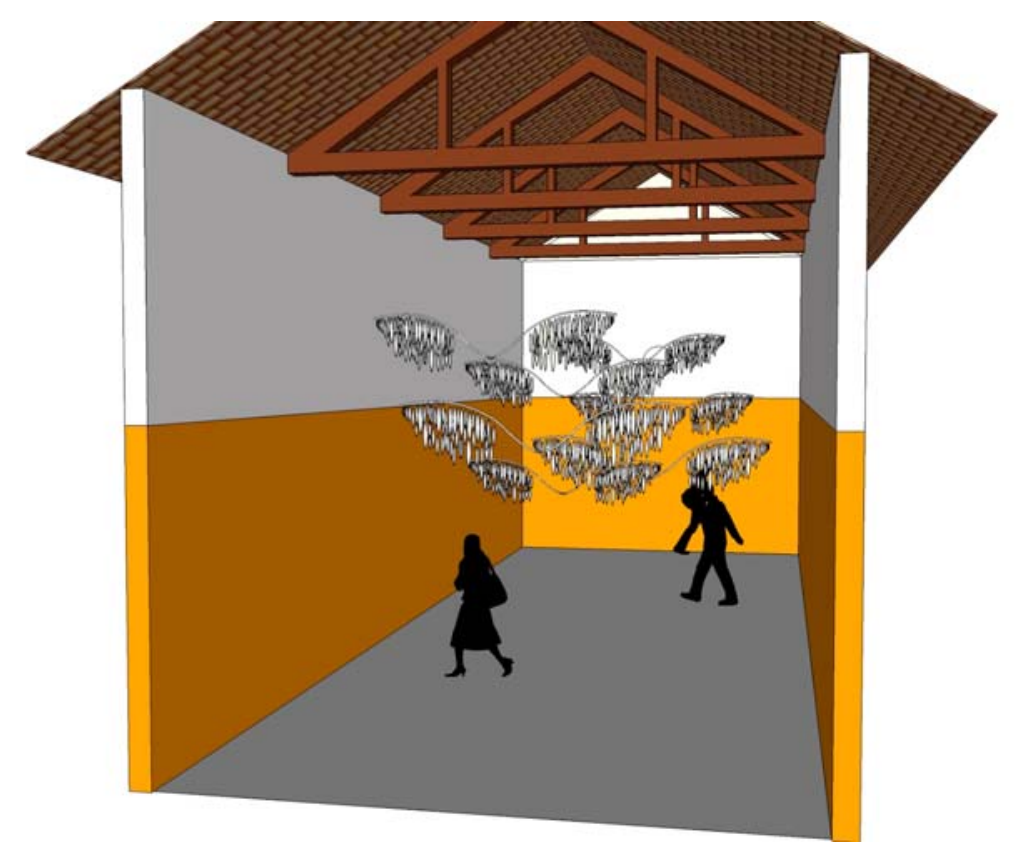




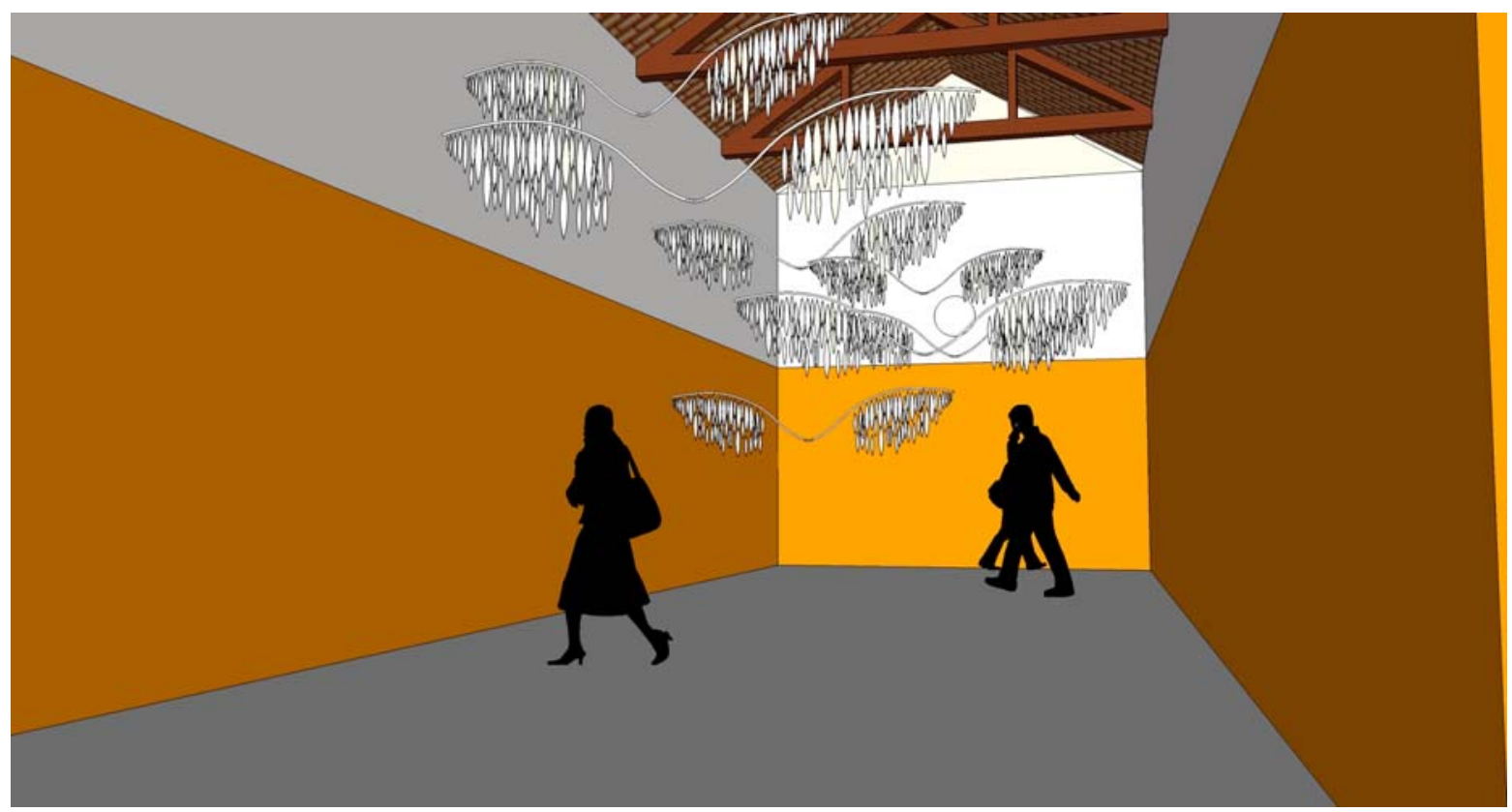


Fig. 40 a 48

Instalação 'asas'

Capela do Morumbi, 2007

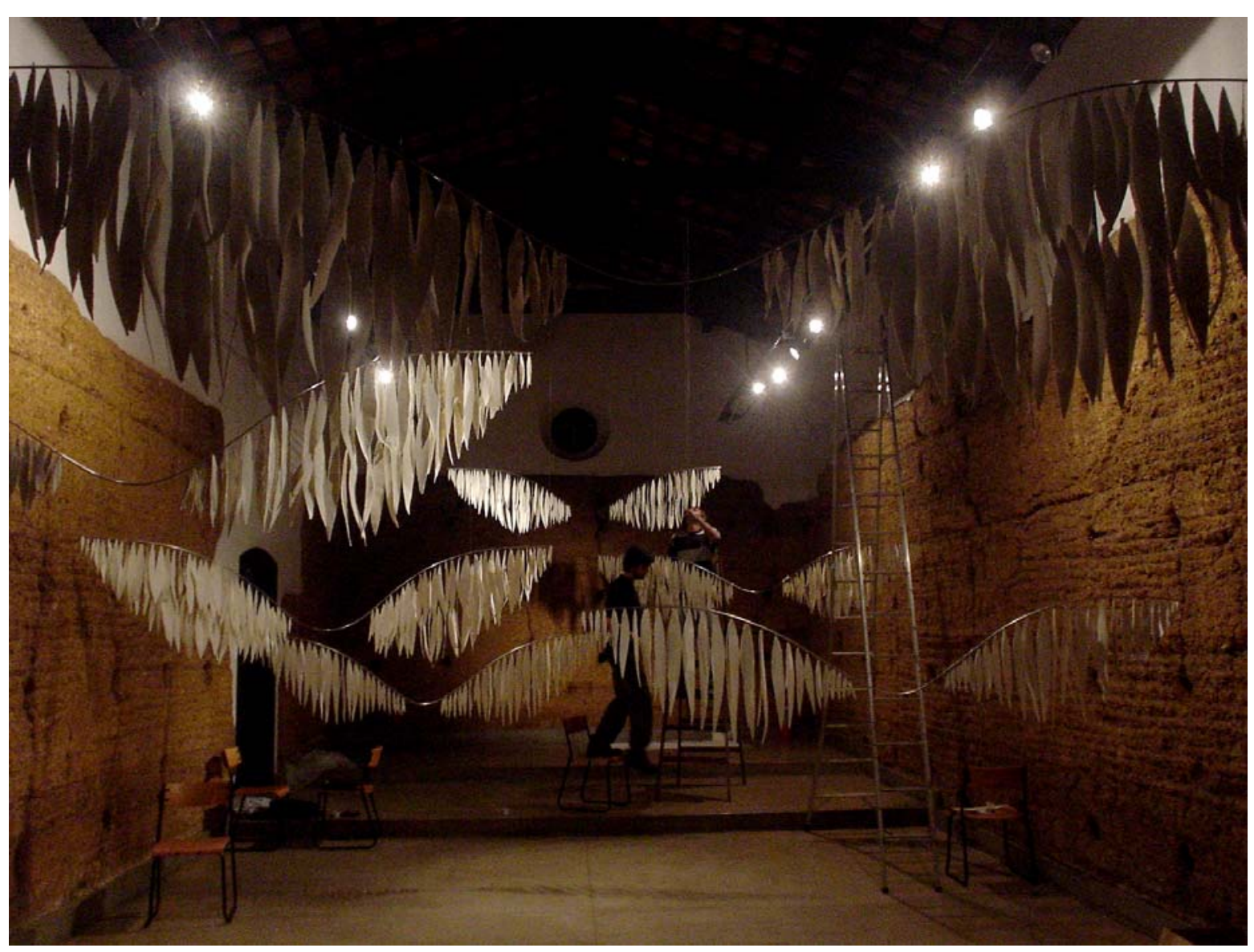




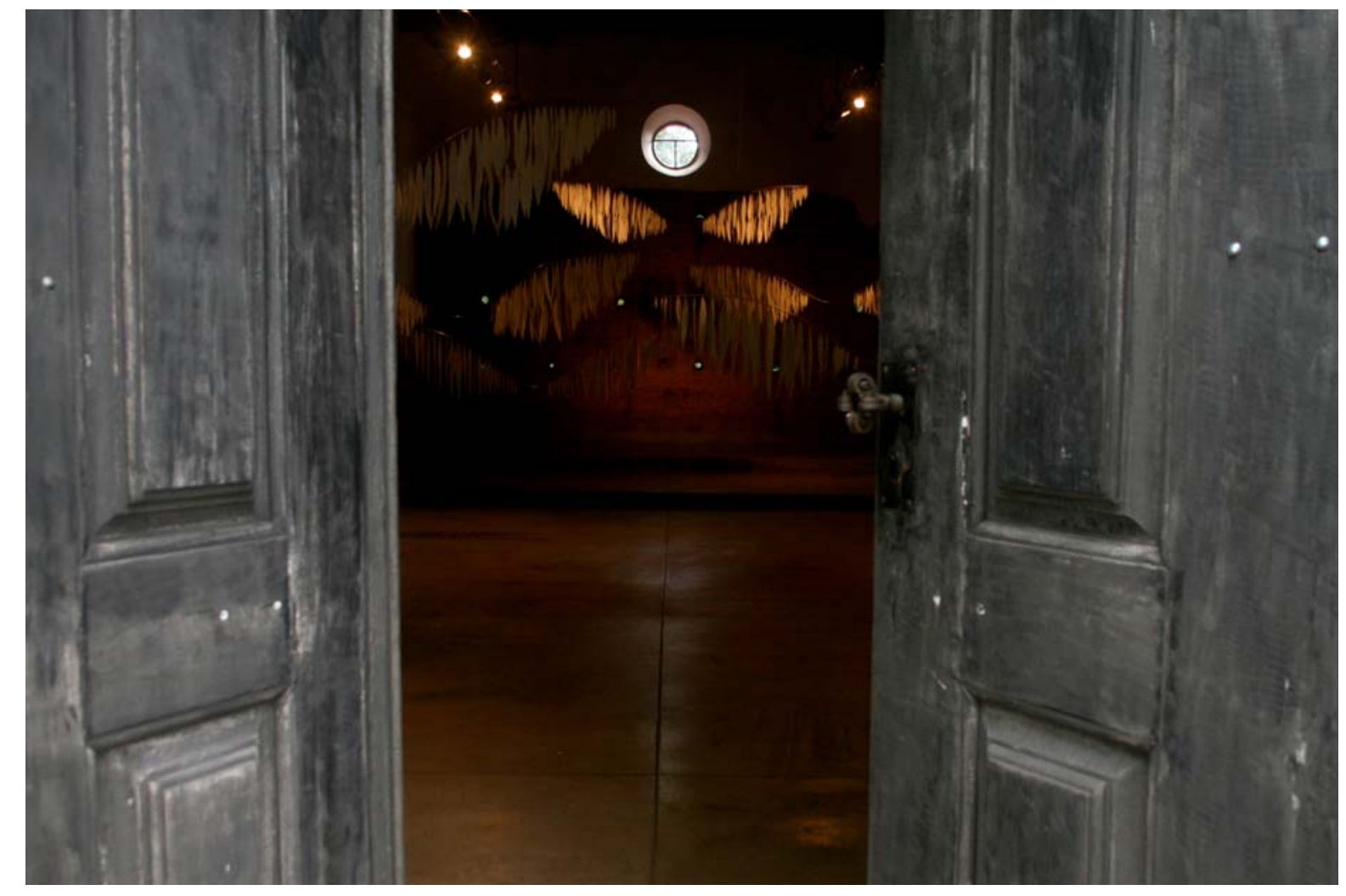




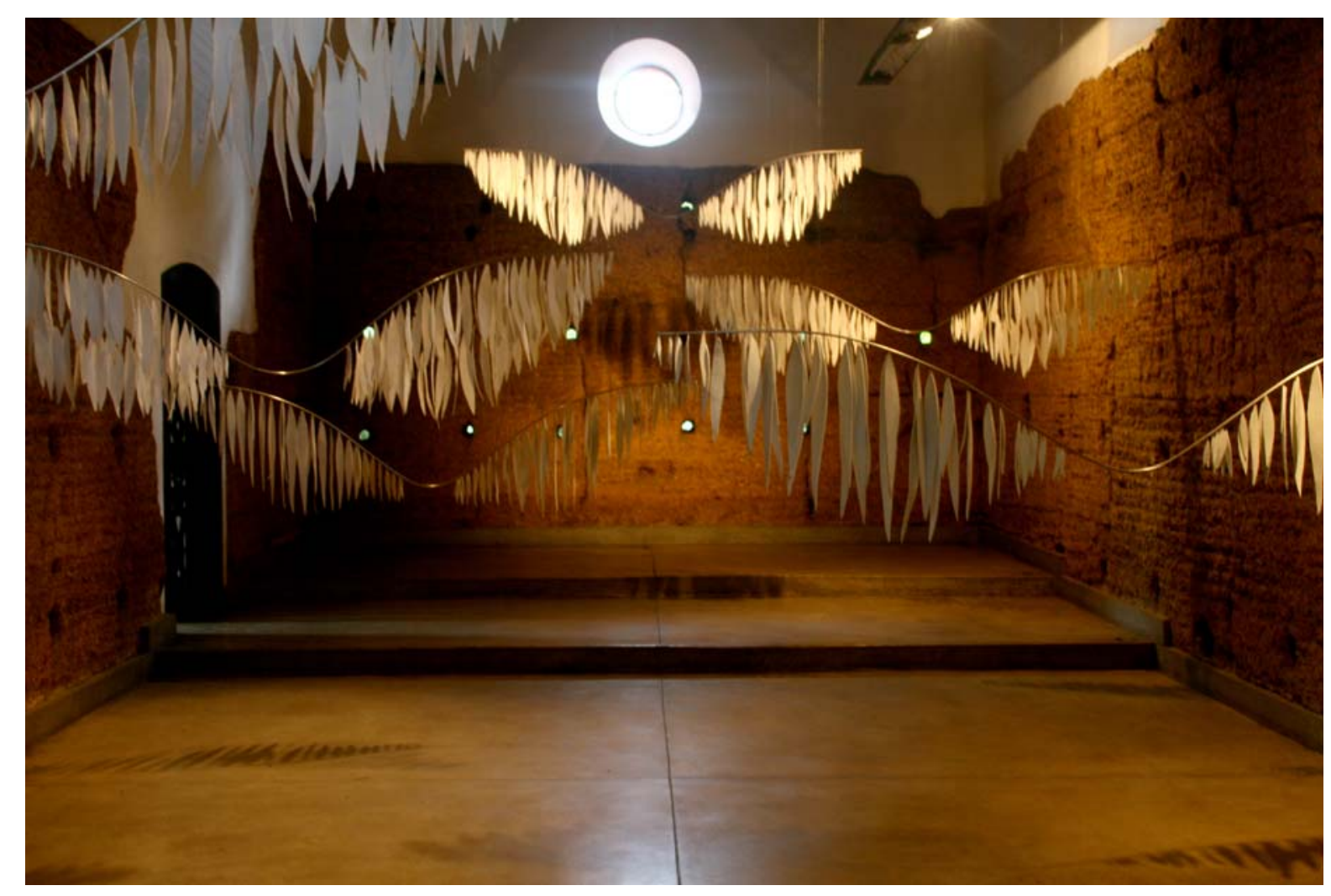




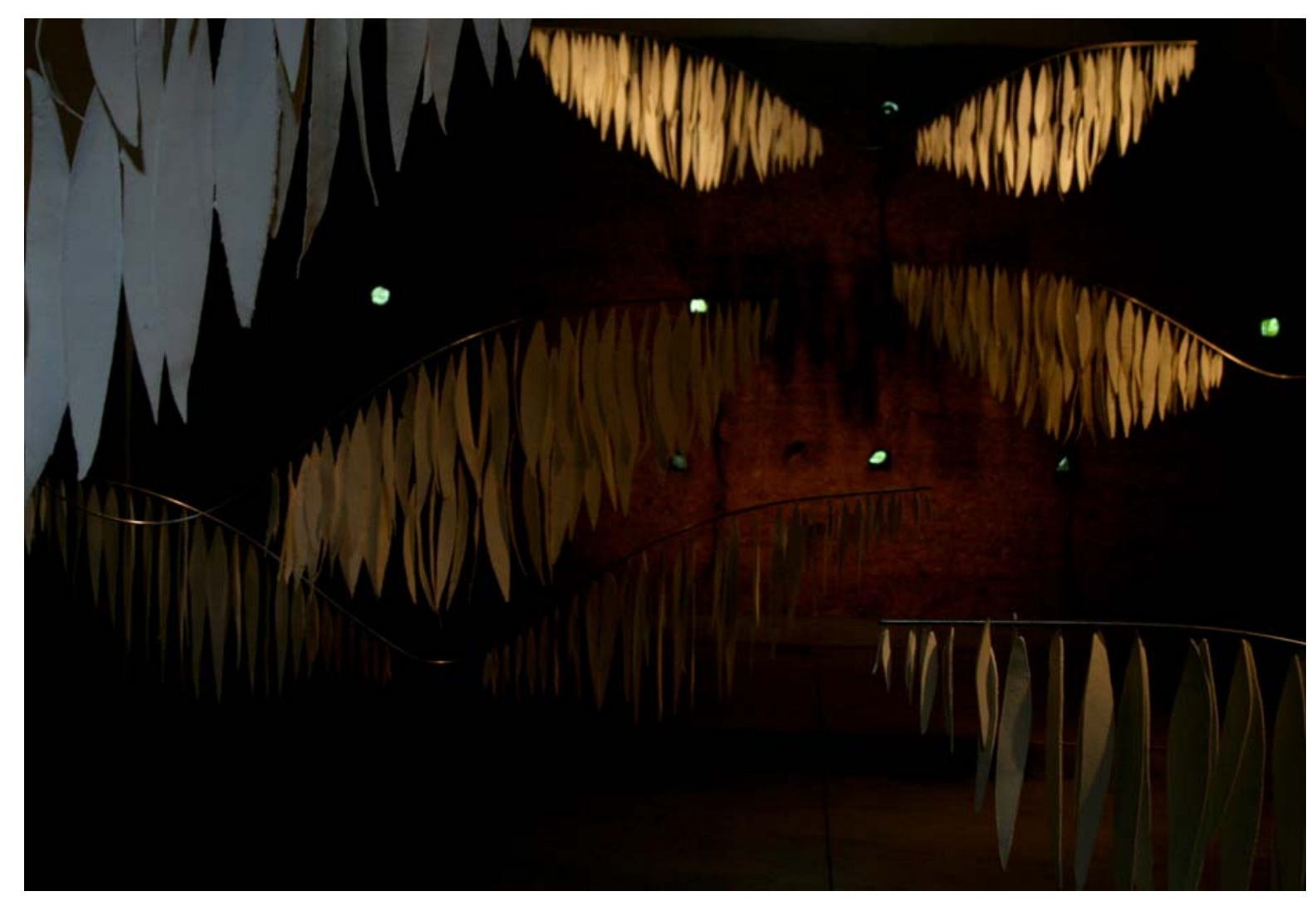




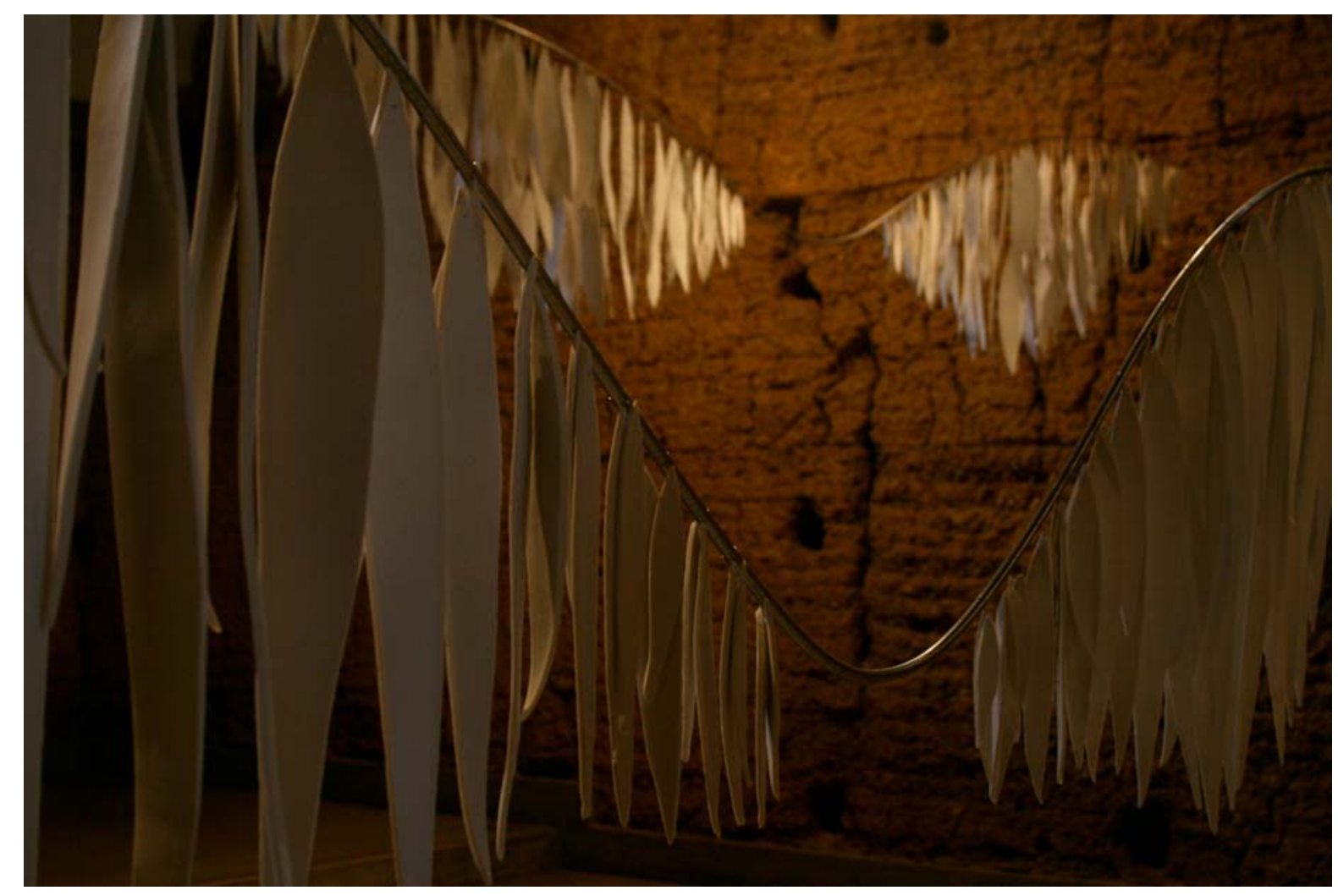




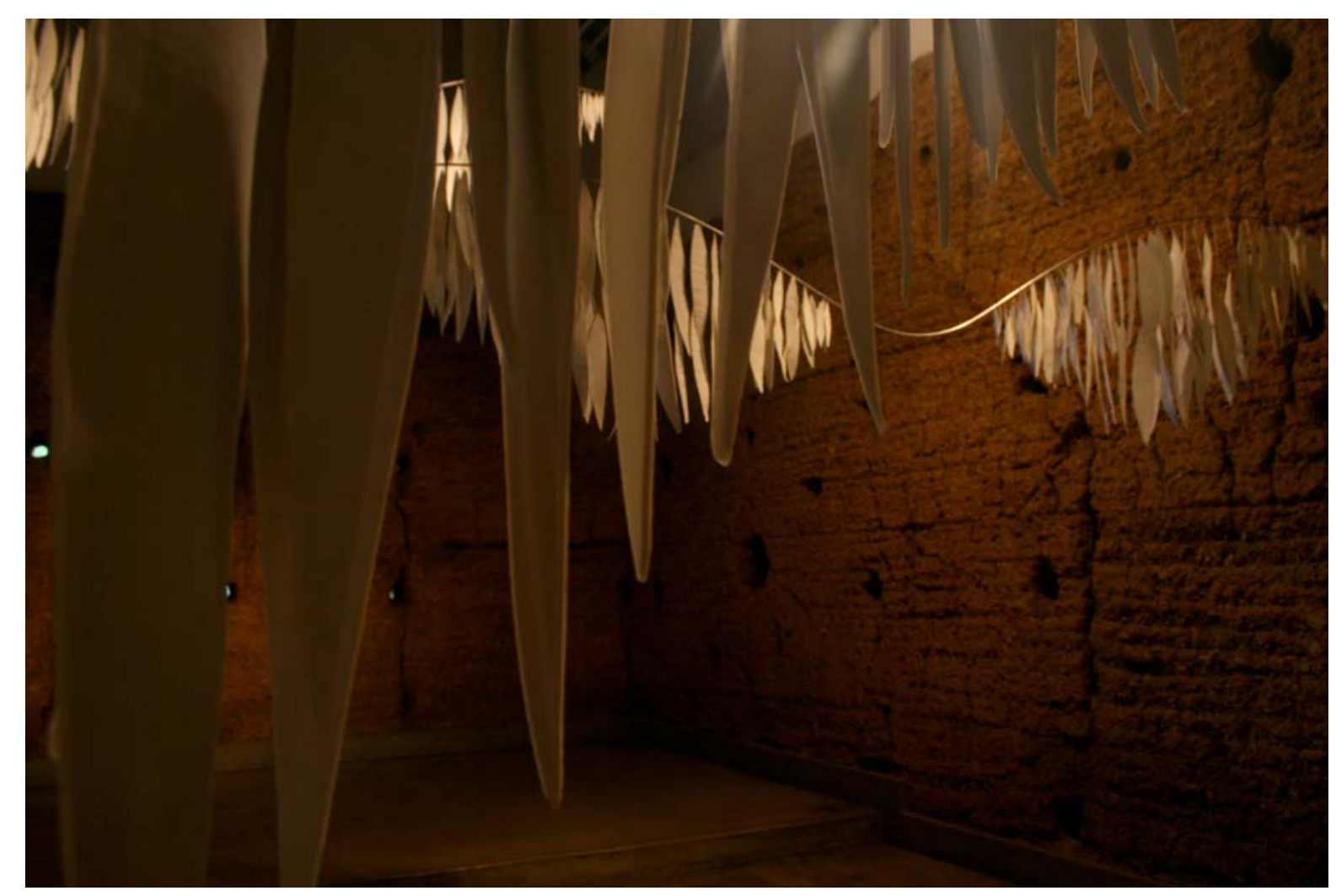




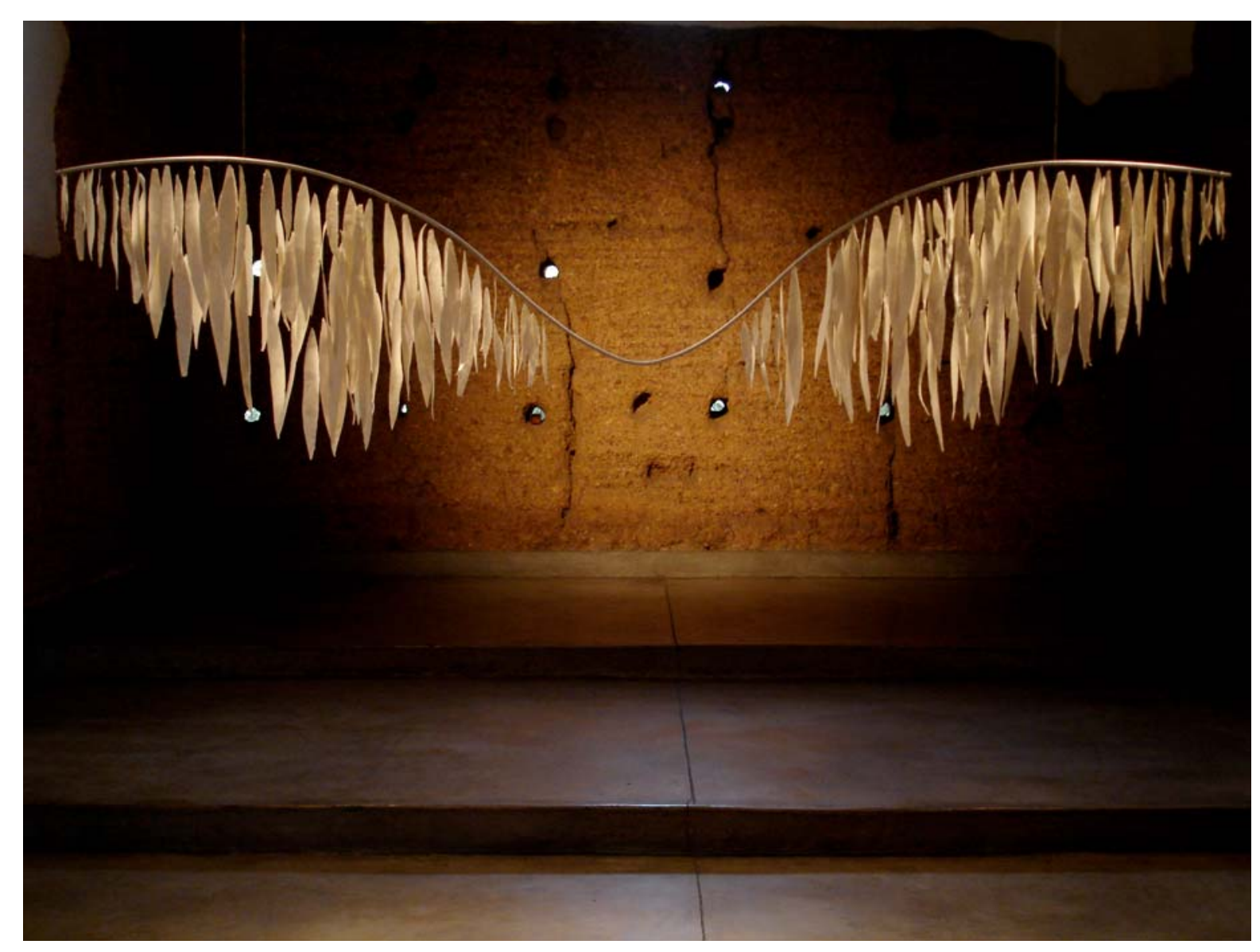




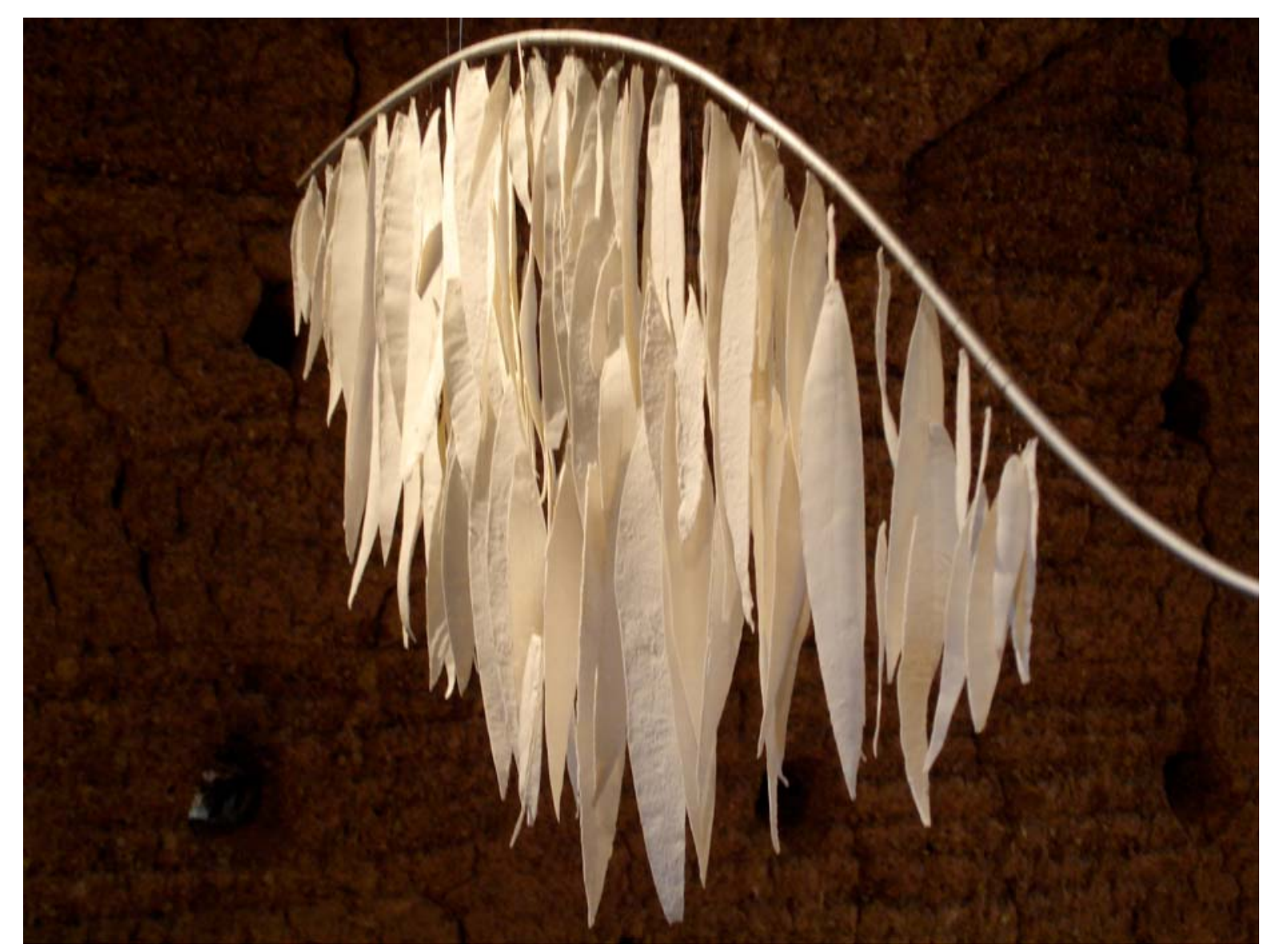




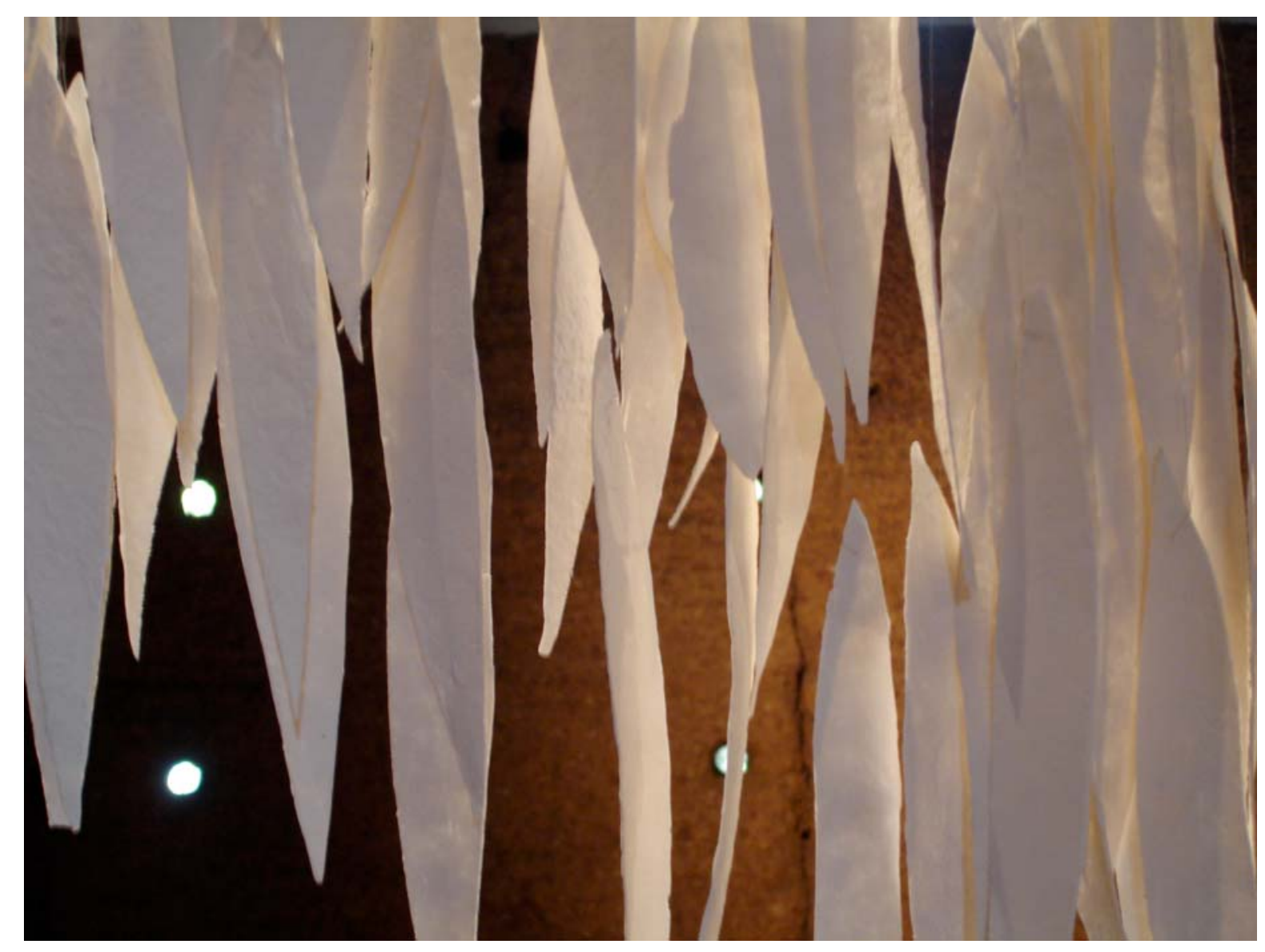




\section{6 - O retorno da imagem fotográfica}

Daniel Rhodes propõe a cerâmica como um meio entre a pintura e a escultura: "(...) as formas da cerâmica que são de caráter altamente dimensional e volumétrico se recobrem de cores, texturas e motivos, que a relacionam com a pintura e o desenho" ${ }^{\prime 17}$. Em alguns trabalhos, há uma fusão entre os elementos bi e tri dimensionais sugerindo uma arte híbrida.

Meu trabalho é permeado por essas duas possibilidades, a relação entre os elementos bi e tri dimensionais se faz fortemente presente. Por um lado, a atenção à forma e volumetria, e ainda a busca pela profundidade desse corpo a partir da translucidez da matéria. Por outro, o foco de interesse é atraído para a superfície dessa matéria quando retomo a imagem fotográfica ao trabalho.

A partir do conhecimento adquirido na relação com o material cerâmico e somado ao que já havia desenvolvido com os processos fotográficos, é possível trabalhar a relação desses dois materiais de forma mais livre e consistente. $A$ cerâmica é uma arte milenar e sua exploração como meio de expressão exige uma aproximação, que eu não tinha quando trabalhava, inicialmente, com sensibilização de suportes fotográficos. A cerâmica possibilita uma infinidade de formas e processos e somente a partir de uma intimidade com o material é possível trabalhar com mais liberdade.

${ }^{17}$ RHODES, 1990: 86 
Esses dois meios se aproximam em seu tempo e temporalidade. Ambos funcionam como cortes do tempo, como fragmentos congelados de um tempo que não pára.

Reiniciei a pesquisa da imagem aliada à cerâmica, partindo de uma técnica de transferência de imagens a partir de fotocópias. As fotocopiadoras trabalham pelo fenômeno natural de eletricidade estática. Um toner de carga negativa é atraído para uma superfície sensível à luz, e esta é exposta à imagem projetada que se deseja copiar. Quando a folha de papel passa através dessa superfície, uma carga elétrica positiva, situada debaixo do papel é atraída até ele. Nessa etapa, a imagem sobre papel se encontra em pó fino e é fixada por calor. Se o papel é retirado antes da fixação, essa imagem pode ser transferida para uma superfície de argila e ser fixada pelo calor na queima de cerâmica. A cor da imagem resultante normalmente é sépia.

Os primeiros testes realizados foram queimados a uma temperatura de $980^{\circ} \mathrm{C}$, resultando em um tom mais avermelhado. Queimado a $1150^{\circ} \mathrm{C}$ resulta num marrom mais escuro.

A imagem da fig.49 vem do trabalho realizado com folhas secas bordadas e presas umas as outras, soltas num rio. A imagem passada para essa cerâmica é dessas folhas.

À imagem pelo processo de transferência de fotocópia aliei uma queima orgânica. O resultado é um esfumato sobre a fotografia, como uma veladura que, ao mesmo tempo, revela e encobre. 
Fig.49

Peça com imagem

em fotocópia sobre cerâmica

e queima orgânica

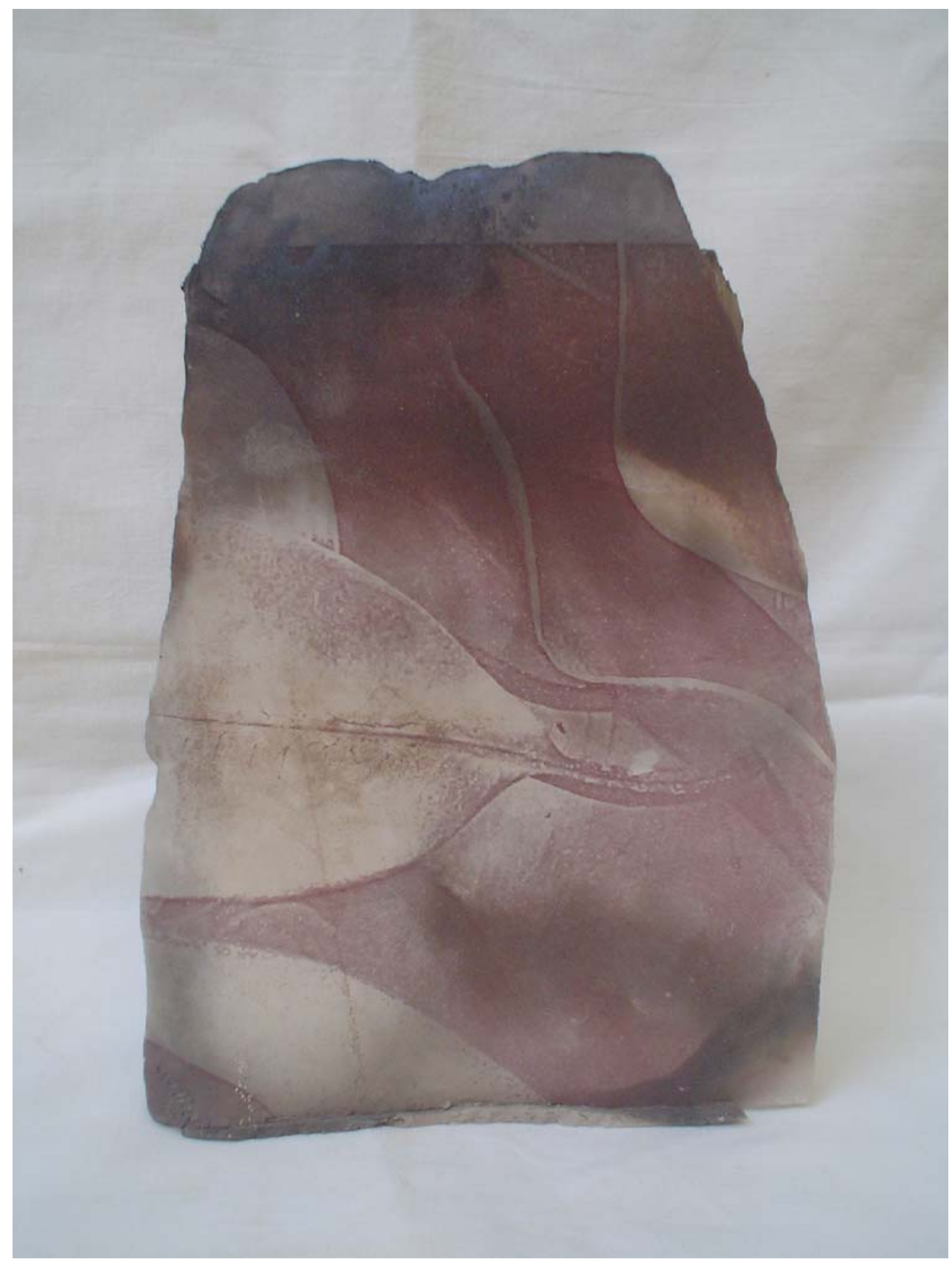




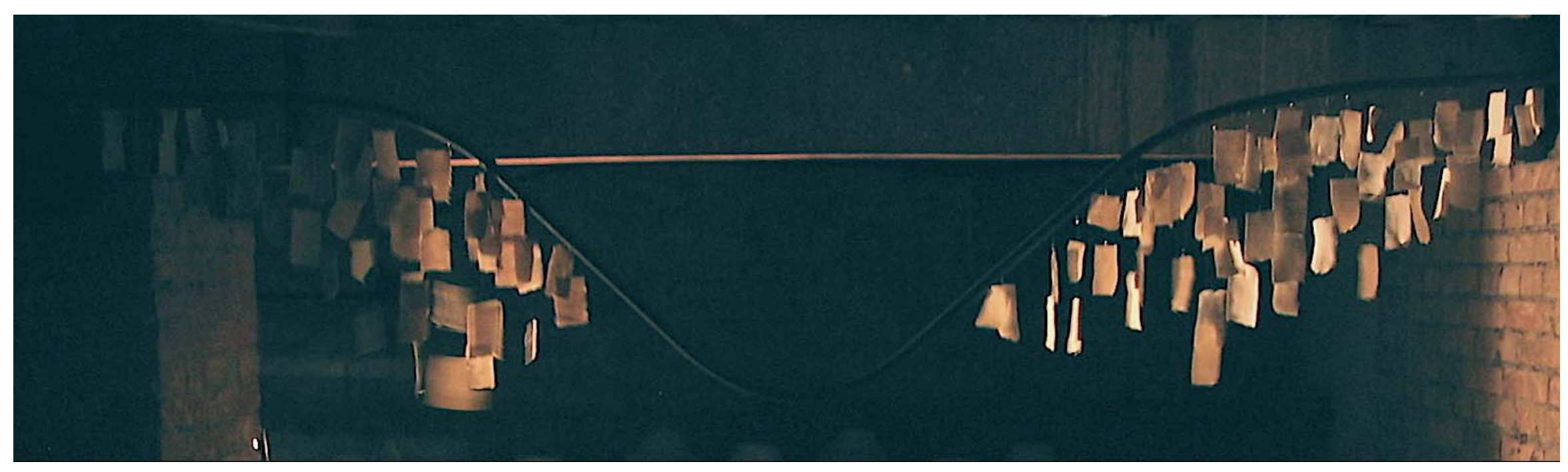

Fig. 50

Asa de porcelana translúcida

com imagem pelo processo

de transferência de fotocópias

Fig. 51

Detalhe da asa

de porcelana translúcida

Um outro trabalho realizado com a mesma técnica é uma asa composta de fragmentos de porcelana translúcida, em que imprimo fragmentos de meus bilhetes aéreos por meio da transferência de imagens de fotocópias. 


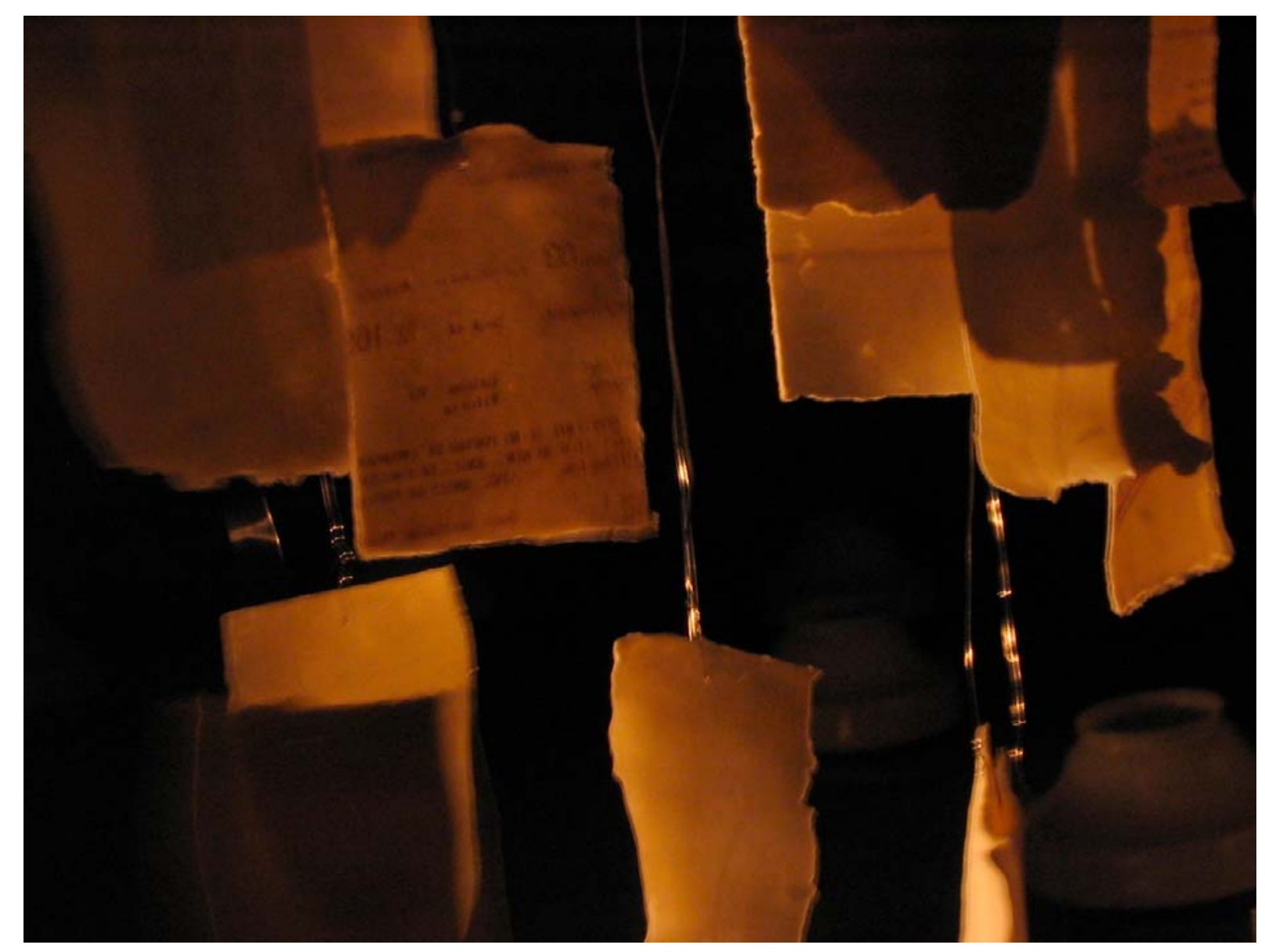


Em seguida, retomei minha pesquisa anterior em processos primitivos de fotografia e num primeiro momento, utilizei o processo da Cianotipia. Esse processo não utiliza o calor como fixador, portanto a imagem deve ser impressa sobre uma superfície cerâmica já queimada. Esse processo é baseado nas propriedades fotossensíveis de alguns sais férricos que, em presença de luz, são sensibilizados, passando ao estado ferroso. Sua denominação viria da terminologia de um dos componentes químicos de sua solução fotossensibilizadora ferricianeto de potássio - ou da cor obtida no processo - cian.

Esse processo tem como característica uma menor sensibilidade à luz quando comparada a papéis industrializados, não sendo possível realizar sua exposição por meio de ampliadores fotográficos. A exposição se dá por contato, devendo ser utilizado um negativo no tamanho da imagem desejada. Há muitas possibilidades de obtenção de negativos, como papel encerado, desenhos, fotogramas - como foi feito no século XIX - ou ainda radiografias, impressões em transparência, ampliações em película ortocromática, conhecida como filme gráfico e fotocópias em transparência . 


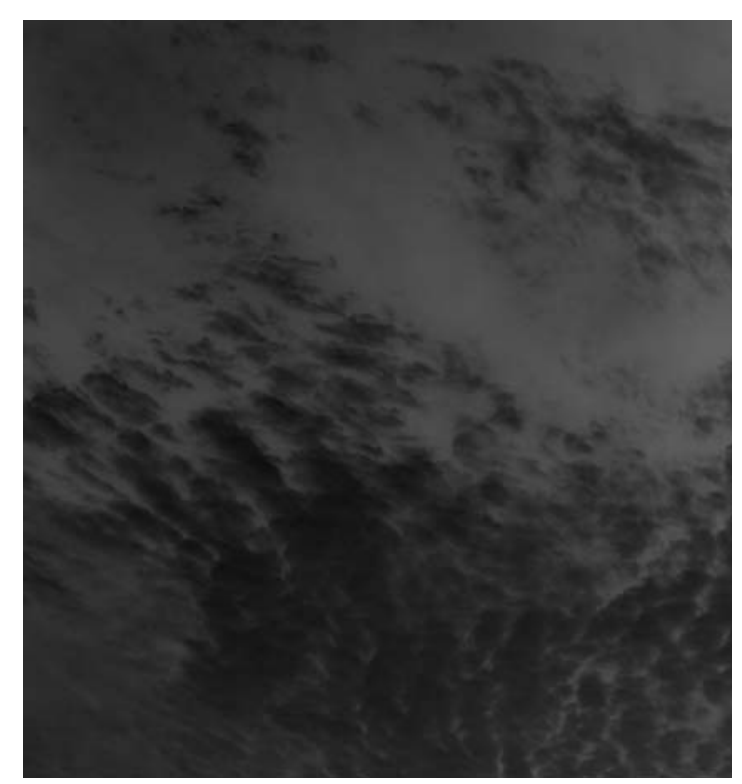

Optei pelos negativos a partir de fotocópias por sua rápida obtenção e por já ter obtido bons resultados anteriormente.

Atrai-me muito a possibilidade de obtenção da imagem pela exposição à luz solar direta. O negativo é colocado sobre o suporte emulsionado. Sobre eles pode ser colocada uma chapa de vidro para facilitar a fixação. O tempo de fixação varia de acordo com a intensidade da luz.

O processo executado com luz natural é muito bonito, pois a imagem está suscetível à ação da luz daquele instante. A imagem impressa não vem apenas do negativo, que registrou um instante de um dia, mas também daquele instante presente em que ela é exposta àquela determinada luz. Naquele momento, há uma junção de dois instantes, passado e presente, de dois tempos-espaços.

Fig. 52

Negativo

Fotocópia em acetato 
Fig.53

Imagem em cianótipo sobre papel

Fig. 54 e 55

Imagem em cianótipo

sobre cerâmica

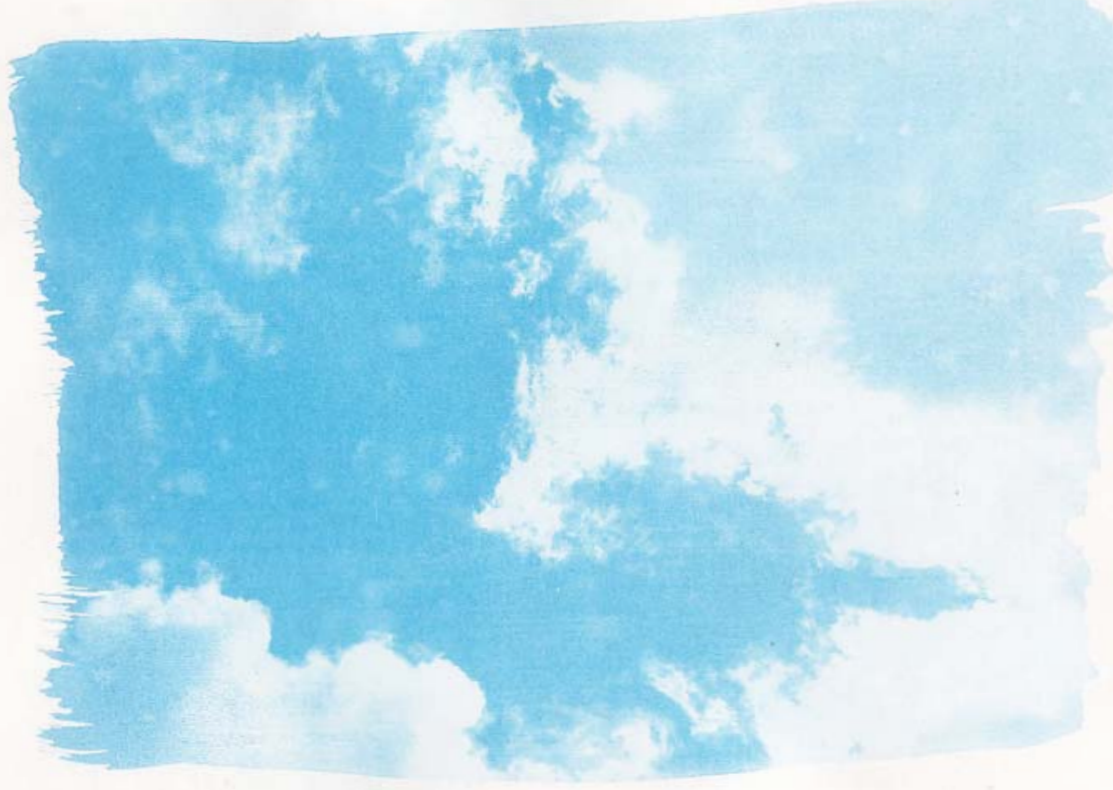



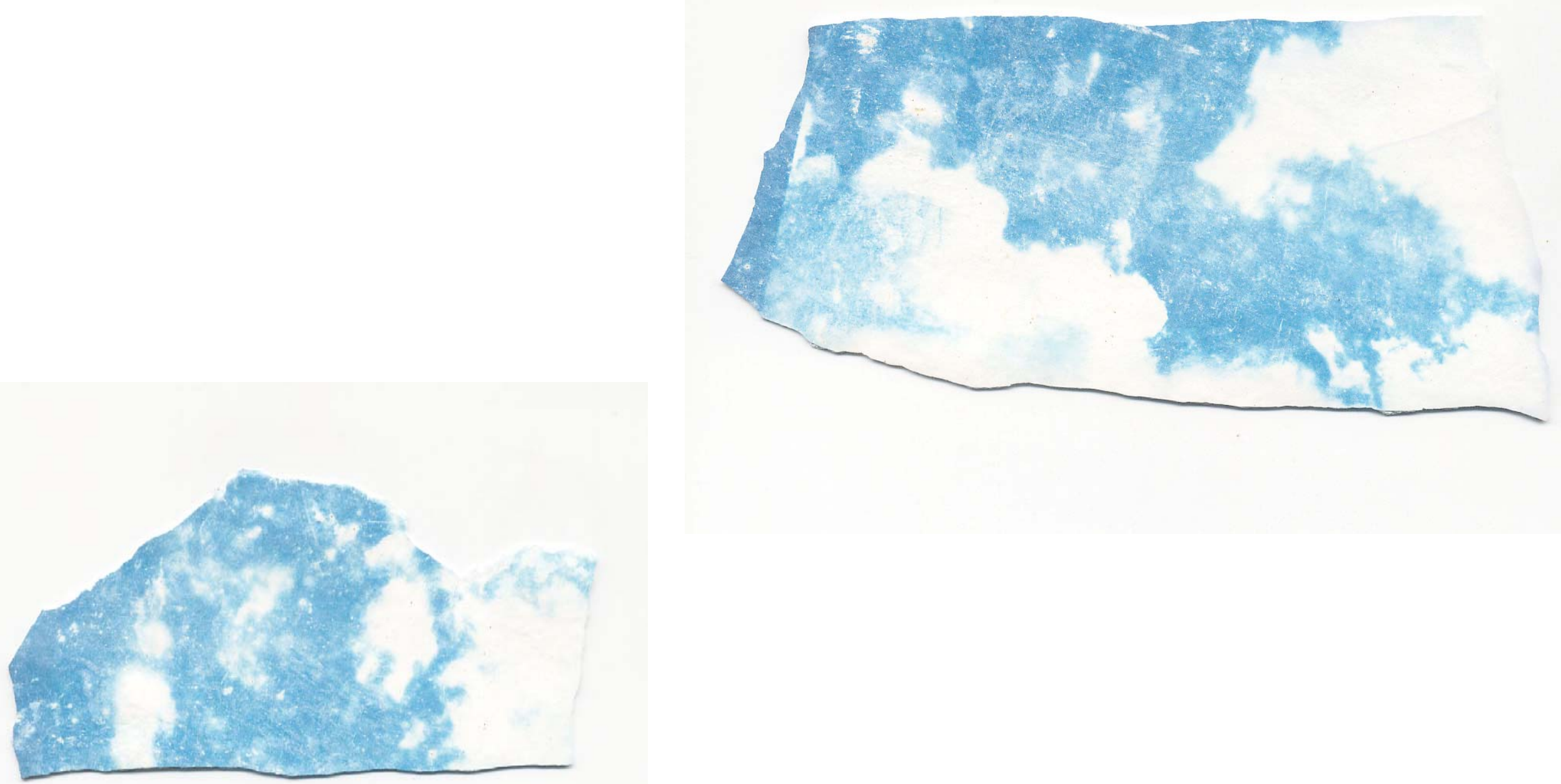
Outras experiências podem ser feitas utilizando emulsões fotográficas com pigmento cerâmico, devendo a peça passar por uma queima após a revelação, para a fixação da imagem, utilizando o processo de Goma Bicromatada. Este é um antigo processo fotográfico baseado no seletivo endurecimento da goma arábica com bicromato de amônio ou potássio e pigmentos, quando exposto à luz ultravioleta. Pode ser utilizado em cerâmica esmaltada ou diretamente sobre o biscoito. 


\section{3 - Reflexões sobre a matéria. A terra}

Nesta etapa da pesquisa, surgem várias questões permeando meu pensamento, aqui apresentadas.

Em minha poética, a matéria é trabalhada de modo intenso. Ao utilizar-me da cerâmica como meio principal de expressão e construção, lido diretamente e de forma fundamental com os quatro elementos materiais - terra, fogo, água e ar - que a filosofia e as ciências antigas, seguidas pela alquimia, colocaram na base de todas as coisas.

Bachelard faz uma discussão aprofundada sobre a matéria e as forças. $O$ autor afirma que "através do duro e do mole aprendemos a pluralidade dos devires, recebendo provas bem diferentes da eficácia do tempo". ${ }^{18}$ A matéria dá o sentido de uma profundidade oculta, ela impõe que o ser superficial seja desmascarado. Cita Jean-Paul Sartre: "O autor trabalhando de algum modo sobre o tema, vê bem que a matéria é reveladora de ser, isto é, reveladora do ser humano: 'A simples revelação da matéria amplia o horizonte até os extremos limites do ser e o dota ao mesmo tempo de um conjunto de chaves para decifrar o ser de todos os fatos humanos. 19 “

\footnotetext{
${ }^{18}$ BACHELARD, 1991: 16

${ }^{19}$ BACHELARD, 1991:92
} 
A relação com a matéria, com a terra ativa meu universo de imagens internas e é esse universo que vem à tona nas formas que crio.

Regina Machado, estudando a arte de contar histórias, afirma que "nunca o ser humano teve tanta necessidade de transitar compreensivelmente pelo mundo 'além das aparências'. Cansado do ilusório apelo da 'realidade', o homem se pergunta hoje como significar sua relação com o mundo(...)". A arte permite esse trânsito compreensível pelos significados fundamentais da vida humana. ${ }^{20}$

Meu trabalho, de alguma forma, ajuda-me na decodificação do mundo e de mim mesma. Nessa relação e diálogo entre o mundo dos símbolos e o mundo material meu trabalho vai sendo tecido.

Acreditando que as coisas acontecem no encontro, na interação, vou desenvolver algumas reflexões sobre o trabalho a partir da relação entre os elementos terra-água, terra-ar, terra-fogo, assim como acontece na cerâmica. A água amolece a terra dura, tornando-a plástica e essa passa a registrar o gesto e manter a forma imposta sobre ela. $\mathrm{O}$ ar seca a terra e torna-a firme novamente, mantendo, transitoriamente, sua forma. O fogo opera a verdadeira transformação da matéria, tornando-a forte, perpetuando a forma.

${ }^{20}$ MACHADO, 2004: 25 


\section{1 - Terra-água. Reflexões sobre a forma}

"Parece-nos indispensável, colocando-nos do ponto de vista da imaginação material dos elementos, estudar um devaneio mesomorfo, um devaneio intermediário entre água e terra. Com efeito, pode-se captar uma espécie de cooperação de dois elementos imaginários, cooperação cheia de incidentes, de contrariedades, conforme a água abranda a terra ou a terra confere a água a sua consistência." 21

Bachelard afirma que a terra tem como primeira característica uma resistência imediata e constante. $\mathrm{O}$ autor fala da matéria dura. Se vista em sua forma exterior, intangível, a dureza pode ser considerada como um mero motivo de exclusão, como seu primeiro não. Se vista em sua dureza íntima, a matéria dura é um tipo de provocação, sua dureza é uma ofensa que não se vinga sem armas, sem ferramentas. "De mão vazia, as coisas são fortes demais". 22

A partir do seu encontro com a água, um novo corpo se forma e novas possibilidades de interação com a matéria se fazem possíveis.

Bachelard fala, então, não mais de uma mão que vinga, mas de "descobrir os poemas do tato, os poemas da mão que amassa."23

A cerâmica explora a capacidade de transformação da terra. Num primeiro momento, em sua relação com a água, a matéria dura e resistente torna-se

\footnotetext{
${ }^{21}$ BACHELARD, 1991:62

${ }^{22}$ BACHELARD, 1991:29

${ }^{23}$ BACHELARD, 1991:65
} 
plástica e amorfa. Surge uma terra generosa, em que a interação é possível. A matéria cede ao gesto, incessantemente, permitindo experimentações, sugerindo novas possibilidades. Alterando as proporções desses materiais, a matéria vai se transformando, de mais sólida e resistente em mais plástica e flexível, até se liquefazer. Em cada fase dessa escala, tipos diferentes de interação são possíveis e novas formas são sugeridas.

Para Bachelard, as realidades materiais verdadeiramente primordiais, tais como são oferecidas pela natureza, são como convites para exercer as nossas forças. Ele afirma que

“... a realidade material nos instrui. De tanto manejar matérias muito diversas e bem individualizadas, podemos adquirir tipos individualizados de flexibilidade e de decisão. Não só nos tornamos destros na feitura das formas, mas também nos tornamos materialmente hábeis ao agir no ponto de equilíbrio de nossa força e da resistência da matéria." ${ }^{24}$

A argila pode ser utilizada desde seu aspecto de massa plástica até sua forma mais liquefeita (barbotina). A partir da massa cerâmica é possível trabalhar a modelagem de corpos, que são mantidos em sua forma e gesto. A partir da barbotina, a relação com a matéria se altera e o diálogo se dá a partir do uso de fôrmas ou do emprego de bases planas de gesso, em que a matéria é espalhada para a secagem, sendo alterada, possibilitando placas muito finas e translúcidas, nas argilas que são preparadas para tal resultado. Em ambos os casos, a matéria desenha junto com o artista.

${ }^{24}$ BACHELARD, 1991:21 


\section{2 - Terra-ar. Reflexões sobre sustentação e gravidade - leveza e peso - o espaço}

A argila molhada vai ganhando sustentação a partir do contato com o ar e vai tornando-se rígida. Uma matéria frágil, mas que sustenta o modelado. A terra deixa de ser uma massa sem forma e pode passar a ser qualquer coisa.

No meu trabalho, a tentativa é de dar forma à leveza. Tento fazer um desenho da leveza, da fluidez, da impermanência. As asas são como um desenho do desejo de voar, do tornar-se leve, do desprender-se. As nuvens são como um desenho do leve, do fluido, do impermanente.

Ítalo Calvino fala muito bem desse desejo de leveza. Ao realizar as conferências transcritas no livro "Seis propostas para o próximo milênio" afirma querer dar uma visão global do seu trabalho e a primeira delas é dedicada à leveza. Fala do momento em que começou a escrever e de sua tentativa de vencer o pesadume do mundo:

"Logo me dei conta que entre os fatos da vida, que deviam ser minha matériaprima, e um estilo que eu desejava ágil, impetuoso, cortante, havia uma diferença que eu tinha cada vez mais dificuldade de superar. Talvez que só então estivesse descobrindo o pesadume, a inércia, a opacidade do mundo qualidades que se aderem logo à escrita, quando não encontramos um meio de fugir a elas.

(...) Às vezes, o mundo inteiro me parecia transformado em pedra: mais ou menos avançada segundo as pessoas e os lugares, essa lenta petrificação não poupava nenhum aspecto da vida. Como se ninguém pudesse escapar ao olhar inexorável da Medusa.(...) O único capaz de decepar a cabeça da 
Medusa é Perseu, que voa com sandálias aladas. Para tal ele se sustenta sobre o que há de mais leve, as nuvens e o vento." 25

Calvino encontra nesse mito uma alegoria da relação do poeta com o mundo, uma lição do processo de continuar escrevendo. Do sangue da Medusa nasce um cavalo alado, Pégaso; o peso da pedra pode reverter em seu contrário.

Neste trabalho há uma tentativa dessa mesma inversão: o pesado que ganha leveza, a terra que vai para o ar, transformação das coisas pesadas em coisas leves.

Bachelard afirma que para encontrar no mundo de sensações e de signos em que vivemos e pensamos, as imagens primordiais, aquelas que explicam, juntos , o universo e o homem, é preciso, em cada objeto, "reavivar algumas primitivas ambivalências". Para tal usa a imagem do rochedo e da nuvem:

"Com muita frequencia o sonhador de nuvens vê no céu nebuloso rochedos reunidos. Eis a recíproca. Eis a vida imaginária trocada. Um grande devaneador vê o céu na terra, um céu lívido, um céu desabado. O amontoado das rochas tem todas as ameaças de um céu tempestuoso. No mundo mais estável, o sonhador então se pergunta:que irá acontecer?"

Existe aqui uma transferência dos valores da solidez e da deformação.

"Cá estamos nós no centro onde são trocados os valores imaginários entre nuvens e rochedos. Ao nosso capricho, iremos fazer do real o imaginário ou do imaginário o real. Quando algumas metáforas são reversíveis, temos a certeza de viver em estado de graça, de imaginação. A vida fica leve. Os mais pavorosos dos pesadelos proporcionam alegrias excitantes, as grandes alegrias cruéis, as alegrias ambivalentes..."

${ }^{25}$ CALVINO, 1990:16

${ }^{26}$ BACHELARD, 1991: 148 
Calvino cita Lucrécio, em De rerum natura, sobre a dissolução da compacidade do mundo, na percepção do que é infinitamente minúsculo, móvel e leve. Para Calvino, Lucrecio quer escrever o poema da matéria, mas adverte que a verdadeira realidade dela se compõe de corpúsculos invisíveis: "o vácuo é tão concreto quanto os corpos sólidos", e ainda é preciso "evitar que o peso da matéria nos esmague". A poesia do invisível, a poesia das infinitas potencialidades imprevisíveis, assim como a poesia do nada, nascem de um poeta que não nutre qualquer dúvida quanto ao caráter físico do mundo: ... "pulverização da realidade, a poeira nos raios de sol, as teias de aranha..."27

Calvino também cita versos de Ovídio, que expressam a delicadeza de alma necessária para ser um Perseu dominador de monstros, quando ele ameniza a dureza do solo com folhas para depositar ali a cabeça da Medusa. Ovídio parte não da realidade física, mas das fábulas mitológicas. Também para ele tudo pode assumir formas novas; o conhecimento do mundo é a dissolução de sua compacidade. Tanto para Lucrecio como para Ovídio, a leveza é um modo de ver o mundo fundamentado na filosofia e na ciência.

Há muitos caminhos possíveis para falar de leveza. Calvino se pergunta qual fio puxar:

“(...) Há o fio que enlaça a lua, Leopardi, Newton, a gravitação universal e a levitação... Há o fio de Lucrecio, o atomismo, a filosofia do amor de Cavalcanti, a magia do Renascimento, Cyrano... (...) para enfrentar a precariedade da vida, o xamã respondia anulando o peso de seu corpo, transportando-se em vôo a um outro mundo, a um outro nível de percepção, onde podia encontrar forças

\footnotetext{
${ }^{27}$ CALVINO, 1990: 21
} 
capazes de modificar a realidade. Em séculos e civilizações mais próximos de nós, nas cidades em que a mulher suportava o fardo mais pesado de uma vida de limitações, as bruxas voavam à noite montadas em cabos de vassouras ou em veículos ainda mais leves, como espigas ou palha de milho."28

O caminho que escolho é a própria visualidade do meu trabalho. Invertendo a terra do seu espaço chão, presa pela gravidade, manipulando essa matéria e levando-a para outro espaço, onde ela brinca com a gravidade, brinca de flutuar. A terra é transformada em outra imagem, a imagem da matéria leve. Por meio dessa reespacialização, o trabalho faz uma reflexão da relação leveza-peso, a partir da síntese entre forma-matéria-tempo.

A respeito dessa relação entre leveza e peso, Bachelard cita Leonardo da Vinci:

"A leveza nasce do peso, e reciprocamente, pagando imediatamente a favor de sua criação, ambos aumentam em força na proporção em que aumentam em vida, e têm tanto mais vida tanto mais movimento têm. Eles também se destroem mutuamente no mesmo instante, na comum vendeta de sua morte. Pois assim é feita a prova, a leveza só é criada se estiver em conjunção com o peso, e o peso só se produz se se prolongar na leveza." ${ }^{29}$

${ }^{28}$ CALVINO, 1990: 40

${ }^{29}$ Leonardo da Vinci, apud BACHELARD, 1991: 272 


\section{3 - Terra-fogo. Reflexões sobre fragilidade e força - transformação}

Também é possível estudar a terra-cerâmica pela ótica da transformação,

da transitoriedade. Através da passagem pelo fogo, uma matéria frágil, impermanente se transforma em matéria forte, resistente às intempéries, à ação do espaço e do tempo.

Bachelard fala da ação desse elemento:

"Não só um novo elemento, o fogo, vem cooperar para a constituição de uma matéria que já reuniu os sonhos elementares da terra e da água, mas também, com o fogo, é o tempo que vem individualizar fortemente a matéria" ${ }^{30}$

Através do fogo, a matéria cerâmica sofre profundas transformações físicas e químicas, fundamentais para a transposição espacial que executo. É o fogo que traz a força necessária para a sustentação da fragilidade desses objetos.

\footnotetext{
${ }^{30}$ BACHELARD, 1991: 69
} 


\section{4 - Considerações Finais}

Busquei alinhavar, neste texto, as relações e referências que norteiam meu trabalho, em pleno processo de construção. Meu trabalho é, de alguma forma, uma tentativa de ordenação de minhas próprias inquietações.

A partir da relação direta e intensa com a matéria, investigo seus limites, ampliando-os, indo além, entrevejo o imaterial. Aproximando-me intimamente da matéria terra, densa, pesada, encontro sua oposição, a leveza, o translúcido.

Acredito ser este um trabalho sobre harmonia e equilíbrio. Harmonia entre o que Bachelard chama de primitivas ambivalências e sua aproximação. No equilíbrio entre diferenças, não como aproximação entre forças opostas visando síntese, igualdade absoluta, pois isso, como afirma Derrida, conduziria à simples neutralização dessas oposições. Equilíbrio visto como relação móvel entre diferentes, num contínuo de ação dentro dessas relações. Equilíbrio e harmonia em que os diferentes se encontram presentes um no outro, completando-se, auto gerando-se.

Tudo acontece no encontro. Isso se faz presente em todo o trabalho, nas relações que estabeleço entre leveza e peso, entre fragilidade e sustentação, terra

e ar, rígido e maleável, passivo e ativo, claro e escuro, interioridade e exterioridade, permanente e efêmero, emoção e razão, consciência e 
inconsciência, destruição e construção, ordem e desordem, sempre buscando esse equilíbrio na dinâmica do encontro e complementação móvel entre diferentes.

Para Suely Rolnik, a singularidade de cada artista está no "pedaço de mundo que escolhe obrar" e nos procedimentos que inventa para isso. Aqui, procuro a leveza na terra, quero justamente a possibilidade de ser outro.

Como disse Evandro Carlos Jardim em minha banca de qualificação, "toda arte está na passagem de um não ser para um ser, na transformaçao da matéria em um afeto novo!" Aqui, meus afetos são leves, são nuvens, são asas, são vôo...

Amanhã podem ser outros. 


\section{5 - Bibliografia}

BACHELARD, Gaston. A terra e os devaneios da vontade: ensaio sobre a imaginação das forças. São Paulo: Martins Fontes, 1991.

BAUMAN, Zigmunt. O mal estar da pós-modernidade. Rio de Janeiro: Jorge Zahar, 1998.

BOURGEOIS, Louise / Marie-Laure Bernadac / Hans-Ulrich Obrist. Louise Bourgeois: destruição do pai, reconstrução do pai. São Paulo: Cosac \& Naify, 2000.

CALVINO, Ítalo. Seis propostas para o próximo milênio: lições americanas. São Paulo: Companhia das letras, 1990.

CHITI, Jorge Fernandez. Diagnostico de materiales cerâmicos: el laboratório del ceramista. Buenos Aires: Ediciones Condorhuasi, 1986.

CHITI, Jorge Fernandez. La cerâmica esotérica: curso de filosofia cerâmica. Buenos Aires: Ediciones Condorhuasi, 1993.

ECO, Umberto. Obra aberta. São Paulo: Perspectiva, 1971.

FREITAS, lole de. lole de Freitas: Sobrevôo. São Paulo: Cosac \& Naify, 2002.

GALVAO, Heloisa. Sensibilidade: suportes fotográficos alternativos. Trabalho de conclusão de curso apresentado ao Centro de Artes da Universidade Federal do Espírito Santo, 1999.

GRINBERG, Norma Tenenholz. Humanóides: transmutações da forma e da matéria. Dissertação de mestrado apresentada a Escola de Comunicações e Artes da Universidade de São Paulo, São Paulo, 1994. 
Lugar com arco. Tese de doutoramento apresentada a Escola de Comunicações e Artes da Universidade de São Paulo, São Paulo, 1999.

JUNG,C.G. Arquétipos e inconsciente colectivo. Barcelona: Ediciones Paidos Ibérica, S.A., 1984.

KOSSOY, Boris. A fotografia como fonte histórica: introdução à pesquisa e interpretação das imagens do passado. São Paulo: Museu da Indústria, Comercio e Tecnologia, 1980.

LAU-TZU. Tao Te Ching. São Paulo: Martins Fontes, 2002.

MACHADO, Regina. Acordais: fundamentos teórico poéticos da arte de contar historias. São Paulo: DCL, 2004.

MIRANDA, Clara Luiza. A crítica nas revistas de arquitetura nos anos 50: a expressão plástica e a síntese das artes. Dissertação apresentada à Escola de Engenharia da Universidade de São Paulo, São Carlos, 1988.

MONFORTE, Luiz Guimarães. Fotografia pensante. São Paulo: Ed. SENAC, 1997.

NARDO, Carlo di - e MINA, Attílio. Tecniche di fotografia creativa, antiche e moderne. Milano: Tecnográfica Milanese, 1983.

NAKANO, Katsuko. Terra, fogo e homem. Tese de doutoramento apresentada a Escola de Comunicações e Artes da Universidade de São Paulo, São Paulo, 1988.

NEWHALL, Beaumont. The history of photografhy. New York: Museum of Modern Art, 1988.

O'DOHERTY, Brian. No interior do cubo branco: a ideologia do espaço de arte. São Paulo: Martins Fontes, 2002. 
PLAZA, Julio. Arte/ciência: uma consciência. Revista Ars, Departamento de Artes Plásticas da Escola de Comunicações e Artes da USP, Ano 1, no 1, 2003. Pg 37-47.

PEIXOTO, Nelson Brissac. Paisagens Urbanas. São Paulo: Senac, 1996.

PONTIFÍCIA UNIVERSIDADE CATÓLICA DO RIO DE JANEIRO. Departamento de Letras. Glossário de Derrida. Rio de Janeiro: Francisco Alves Editora, 1976

RHODES, Daniel. Arcilla y vidriado para el ceramista. Barcelona: Ediciones CEAC,1990.

RODRIGUES, Maria Regina. Obras em processo: interações comunicacionais no processo de criação de duas ceramistas brasileiras. Tese de doutoramento apresentada à Pontifícia Universidade de São Paulo, São Paulo, 2004.

ROLNIK, Suely. Subjetividade em obra. Lygia Clark, artista contemporânea. 2002 Texto extraído do site www.pucsp.br/nucleodesubjetividade

SALLES, Cecília Almeida. Crítica genética: uma (nova) introdução. São Paulo: EDUC, 2000.

Paulo: Fapesp, Annablume, 2004

SCOTT, Paul. Cerâmica y técnicas de impresión. Barcelona: Editorial Gustavo Gili, SA, 1997.

Ceramics and print. London: A\&C Black, 2002.

TASSINARI, Alberto. O espaço moderno. São Paulo: Cosac \& Naify, 2001.

TUCKER, William. A linguagem da escultura. São Paulo: Cosac \& Naify, 2001.

VIEBG, Reinhard. Formulário Fotográfico. São Paulo: Ed. Iris, 1985. 
6 - Anexos 


\section{Texto de Megumi Yuasa}

"Os acontecimentos mais ricos ocorrem em nós muito antes que a alma se aperceba deles. E quando começamos a abrir os olhos para o visível, há muito que estávamos aderentes ao invisível."

Gabriele D'Annunzio

Escritor italiano 1863-1938

Duas qualidades se descacam, interagindo e se complementando, na travessia de Heloisa.

A primeira é a objetividade nas pesquisas com clareza de um observador de laboratório científico, focando sem divagações o alvo desejado. Busca a origem dos processos, não como volta ao passado, mas para utilizar os sólidos e saudáveis princípios e técnicas dos pioneiros na sua criação. É a procura da origem na volta para o futuro. Ou futuro para encontrar princípios?

A segunda qualidade é a imaginação poética que reinterpreta espaçotempo, subvertendo a ordem. Intui ainda a interação entre conhecimento e infinito desconhecido, matéria, formas, coisas, disciplinas diversas, sensações, acasos, ação, absurdo, sonhos, razão, emoção, sentimento, metáforas, Vida-Morte, cotidiano e criação, como observação da ordem no caos.

As escolhas são incomuns, mas lúcidas, inspiradas na imaginação material e na fé que aproxima aparentes incompatíveis.

Substância-matéria de um lado, ondas de energia de outro, ou pesoopacidade e leveza-translucidez-transparência, ou ainda, visível-invisível. 
Fotografia, cerâmica, luz-sombra, natureza e outros eventos revelados ou ocultos, mediados pela palavra, conceitos e outras tensões, buscam aproximações, trocas, diálogos, interações, simbioses, como a conspirar em comunhão para a significação do todo na produção de conhecimento e nova leitura.

Imaginação, pesquisa, movimento, transformação, ação conjunta indivisível e simultânea.

As descobertas em cada etapa, autônomas, completas como apariçõesemergências são consideradas no despertar poético e apresentadas em performances e instalações.

A pesquisa-processo é a obra, registro recomeço.

A propósito: belo, forte e pleno, o projeto e execução de folhas costuradas, armadas e soltas no rio Cumuruxatiba na Bahia. Pleno de generosidade e densidade poética, forte na leveza e belo no ritmo e na delicadeza.

Doce é o sabor da espera do próximo evento, poesia de Heloisa, porque nas pegadas do visível habita ansioso o invisível infinito, pronto para emergir e se revelar para o leitor atento, escolhido.

Megumi,

fim de inverno causticante de 2007

P.S. O precurso de Heloisa é Justo, Belo e Verdadeiro, citando o saudoso artista mineiro Amílcar de Castro que costumava parafrasear os gregos.

As três palavras se complementam, formando um único conceito aberto. 
Texto da exposição 


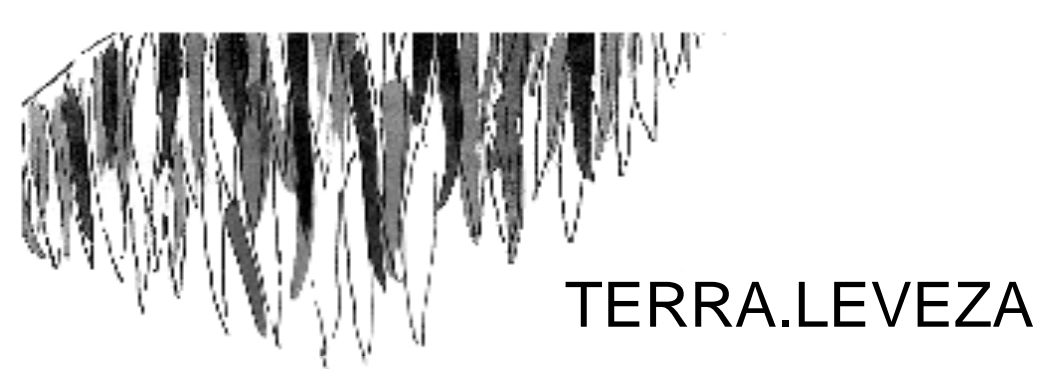

Essa exposição é resultado da minha pesquisa de mestrado em Poéticas Visuais na ECA-USP. A pesquisa em questão trata do desenvolvimento de uma 'Poética da Leveza' a partir do elemento terra.

Trabalho com a terra, uma matéria densa, resistente, que tende ao peso, procurando seus limites, buscando leveza e quase imaterialidade. Manipulando a matéria, dando-lhe uma nova conformação, alterando sua espacialidade, esta ganha um outro conjunto de relações, de interações, de referenciais e passa a ser percebida de forma diferente, revelando sua indeterminação.

Pesquiso a porcelana translúcida, uma matéria que apresenta muita resistência e dureza, mesmo em corpos muito finos. O translúcido possibilita a imersão na superfície. Junto com a luz, o olhar pode penetrar a superfície-corpo-matéria. A translucidez é a possibilidade do olhar adentrar a matéria junto com a luz, quase atravessá-la.

Crio corpos leves, que aliam a aparente leveza e fragilidade à força necessária à sua sustentação no mundo. Esses corpos existem no limite entre sustentável e insustentável. Eles abordam a relação entre leveza e peso, entre matéria e imaterialidade. Trabalho com o frágil, com o tênue. A matéria terra, através de sua nova conformação e disposição espacial, ganha uma outra visualidade, a visibilidade das coisas do ar. Neste contexto nasce o trabalho "Asas". Esse trabalho fala da vontade de desprender-se do chão, de tornar-se leve, do desejo de voar.

As nuvens são matéria sem rigidez, em movimento e transmutação constante. Uma mescla de transparência e opacidade. Vejo-as como desenhos impermanentes ou desenhos da impermanência e da leveza. Na obra "Nuvens" procuro uma aproximação destas não em sua forma, em sua multiplicação, mas em sua leveza, seu silêncio, seu tempo e temporalidade próprios. Essa é para mim uma obra silenciosa. Escuto seu silêncio, seu movimento leve e flutuante. Ela parece habitar um outro tempo, um tempo muito próprio, assim como as nuvens.

No meu trabalho tento fazer um desenho da leveza, da fluidez, da impermanência. Invertendo a terra do seu espaço chão, manipulando-a e levando-a para outro espaço, onde ela brinca com a gravidade, a terra é transformada em outra imagem, a imagem da matéria leve. Por meio dessa reespacialização, o trabalho faz uma reflexão da relação leveza-peso, a partir da síntese entre forma-matéria-tempo.

Heloisa Galvão 


\section{7 - Créditos das Imagens}

Fig. 1 a 8 - Heloisa Galvão

Fig. 9 - Samir Melhem

Fig. 10 a 28 - Heloisa Galvão

Fig. 29 a 33 - Cassiana Haroutiounian

Fig. 34 a 39 - Projeto montagem da exposição: Júlia Cannavale Pacheco

Fig. 40 - Heloisa Galvão

Fig. 41 a 45 - Cassiana Haroutiounian

Fig. 46 a 48 - Ana Galotti

Fig. 49 a 55 - Heloisa Galvão 